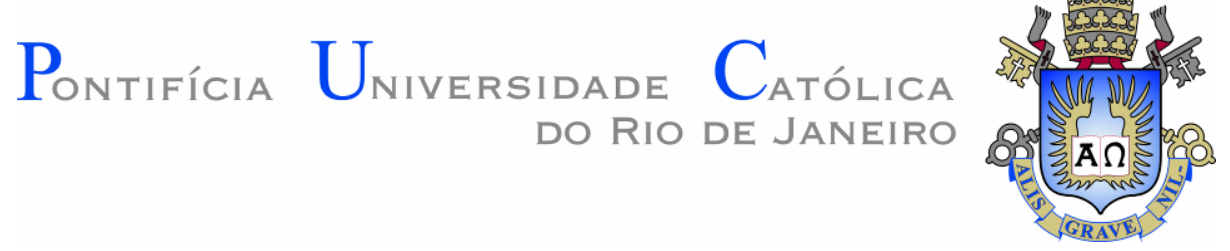

Fabiano Taranto Pereira Rodrigues

Cotidiano Escolar e Religião no ensino fundamental: concepções e relações no espaço escolar

Dissertação de Mestrado

Orientador: Prof. Pedro Pinheiro Teixeira 


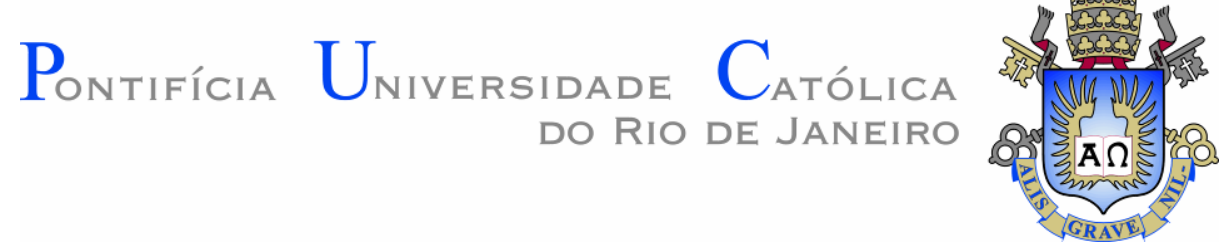

Fabiano Taranto Pereira Rodrigues

\title{
Cotidiano Escolar e Religião no ensino fundamental: concepções e relações no espaço escolar
}

\begin{abstract}
Dissertação apresentada como requisito parcial para obtenção do grau de Mestre pelo Programa de Pósgraduação em Educação do Departamento de Educação do Centro de Teologia e Ciências Humanas da PUC-Rio. Aprovada pela Comissão Examinadora abaixo assinada.
\end{abstract}

\author{
Prof. Pedro Pinheiro Teixeira \\ Orientador \\ Departamento de Educação - PUC-Rio \\ Prof ${ }^{a}$ Silvana Soares de Araújo Mesquita \\ Departamento de Educação - PUC-Rio \\ Prof $^{a}$. Pâmela Sueli Esteves \\ UERJ \\ Prof ${ }^{a}$ Maria Cristina Monteiro Pereira de Carvalho \\ Coordenadora Setorial do Centro de Teologia e \\ Ciências Humanas - PUC-Rio
}


Todos os direitos reservados. É proibida a reprodução total ou parcial do trabalho sem autorização da universidade, do autor e do orientador.

\section{Fabiano Taranto Pereira Rodrigues}

Graduou-se em Licenciatura (2016) e Bacharelado (2016) em História na Pontifícia Universidade Católica do Rio de Janeiro (PUC-Rio). Atualmente é mestrando em Educação na PUC-Rio. Atua nas áreas de: Educação; Ensino Religioso; Intolerância Religiosa; História das Religiões em suas aproximações com o campo do currículo e cotidiano escolar. Desde 2017 professor de história da Prefeitura Municipal de Mesquita-RJ.

Ficha Catalográfica

Rodrigues, Fabiano Taranto Pereira

Cotidiano escolar e religião no ensino fundamental: concepções e relações no espaço escolar / Fabiano Taranto Pereira Rodrigues; orientador: Pedro Pinheiro Teixeira. 2019.

149 f.; $30 \mathrm{~cm}$

Dissertação (mestrado)-Pontifícia Universidade Católica do Rio de Janeiro, Departamento de Educação, 2019.

Inclui bibliografia

1. Educação - Teses. 2. Religião. 3. Escola. 4. Concepções. I. Teixeira, Pedro Pinheiro. II. Pontifícia Universidade Católica do Rio de Janeiro. Departamento de Educação. III. Título.

CDD: 370 


\section{Agradecimentos}

Aos membros da banca avaliadora, por aceitarem participar e avaliar e contribuir com esse trabalho.

Ao querido mestre e professor Marcelo Andrade, que me recebeu de braços abertos desde a iniciação científica e que iniciou esse trabalho

Ao meu orientador Pedro Teixeira, por ter me acolhido como orientando após um momento difícil. Por ter lido, contribuído e trocado com tanta atenção e dedicação para esse trabalho.

À minha amada esposa Mariana, que me acompanha desde antes de qualquer vida acadêmica. Obrigada por todo carinho, compreensão e apoio nos momentos em que o trabalho pesava. Te amo.

Aos meus pais, Lúcia e Manuel, que me deram todo o suporte durante toda a vida para que eu chegasse nesse momento. Obrigado por sempre me apoiarem e estarem sempre comigo.

A todos os amigos do GECEC e do Diversias, que contribuíram com as discussões, com a elaboração dos questionários e por todo suporte emocional que tanto precisamos.

À Luana, pela ajuda com as transcrições.

A todos os meus colegas do mestrado, por sempre contribuírem com reflexões necessárias.

A todos os/as professores/as, estudantes e escolas que aceitaram participar da pesquisa. Sempre me receberam de boa vontade e de braços abertos para que eu conduzisse o trabalho de campo e contribuíram enormemente para o desenvolvimento desse trabalho.

A todos/as os/as funcionários/as e professores/as Departamento de Educação da PUC-Rio pelos ensinamentos, suporte e ajuda.

Ao CNPq pelo auxílio financeiro. 


\section{Resumo}

Rodrigues, Fabiano Taranto Pereira; Teixeira, Pedro Pinheiro (orientador) - "Cotidiano Escolar e Religião no ensino fundamental: concepções e relações no espaço escolar". Rio de Janeiro, 2019. 149 p. Dissertação de Mestrado - Departamento de Educação, Pontifícia Universidade Católica do Rio de Janeiro.

A escola é um local onde convivem pessoas com diversas crenças religiosas. A presença da religião na escola passa por vários fatores, como a presença do ensino religioso. Mas passa também pelas concepções religiosas que os atores escolares tem e como eles lidam com a religião no espaço escolar. Nesta pesquisa, investigamos o a relação da escola com a religião através de um estudo que envolveu 10 escolas da Zona Sul do Rio de Janeiro, em duas etapas, durante os anos de 2017 e 2018. Aplicamos questionário nas 10 escolas, durante o ano de 2017 e escolhemos uma para realização de observações e entrevistas no ano de 2018. Os resultados da pesquisa indicam que existe uma variedade de concepções religiosas entre os atores escolares. No entanto, é possível notar que estão presentes concepções intolerantes em uma parte dos alunos e que as religiões que eles pertencem tem influência sobre essas concepções. É possível também indicar que esse não é uma temática que seja uma preocupação central no ambiente escolar. Concluímos que mais pesquisas sobre essa discussão são essenciais para entendermos melhor sobre essa temática

\section{Palavras-chave}

Religião; Escola; Diversidade; Ensino Religioso 


\section{Abstract}

Rodrigues, Fabiano Taranto Pereira; Teixeira, Pedro Pinheiro (Advisor) "Daily life and religion in elementary school: conceptions and relationships in school space". Rio de Janeiro, 2019. 149 p. Dissertação de Mestrado - Departamento de Educação, Pontifícia Universidade Católica do Rio de Janeiro.

The school is a place where people with diverse religious beliefs coexist. The presence of religion in school goes through several factors, such as the presence of religious teaching. But it also goes through the religious conceptions that the school actors have and how they deal with religion in the school space. In this research, we investigated the relationship between school and religion through a study that involved 10 schools in the South Zone of Rio de Janeiro, in two stages, during the years 2017 and 2018. We applied a questionnaire in the 10 schools during the year 2017 and we chose one to conduct observations and interviews in the year 2018. The survey results indicate that there is a variety of religious conceptions among school actors. However, it is possible to notice that intolerant conceptions are present in a part of the students and that the religions that they belong to have influence on these conceptions. It is also possible to indicate that this is not a theme that is a central concern in the school environment. We conclude that more research on this discussion is essential to better understand this issue

\section{Keywords}

Religion; School; Diversity; Religious education 


\section{Sumário}

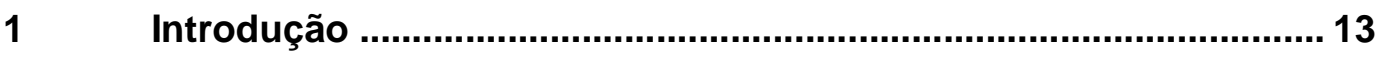

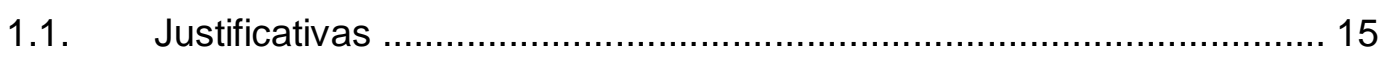

1.2. Questões de pesquisa .............................................................. 19

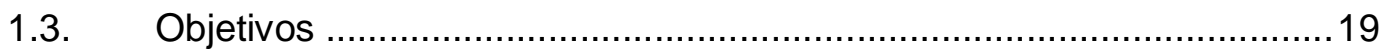

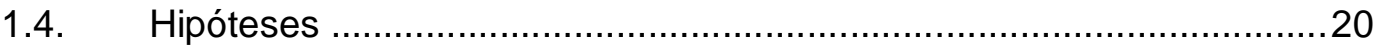

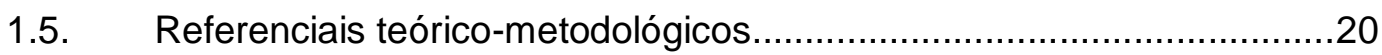

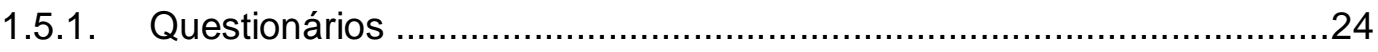

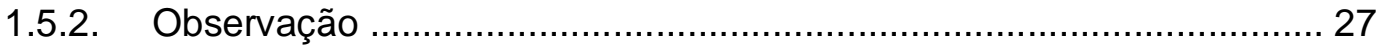

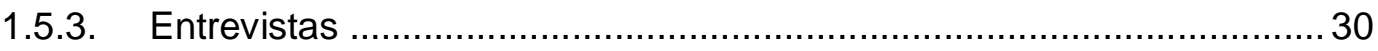

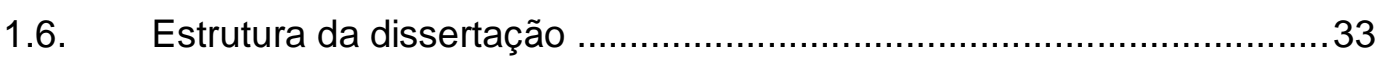

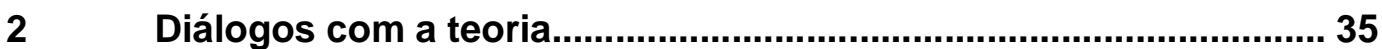

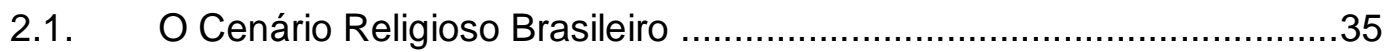

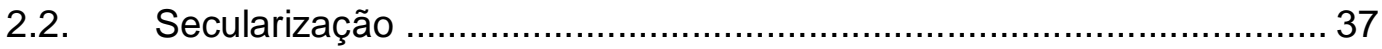

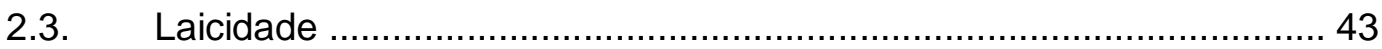

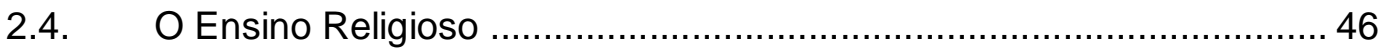

2.4.1. Ensino e religião na Colônia ........................................................ 47

2.4.2. Ensino e religião depois dos jesuítas: Império ................................... 48

2.4.3. Ensino e religião na Primeira República ..........................................50

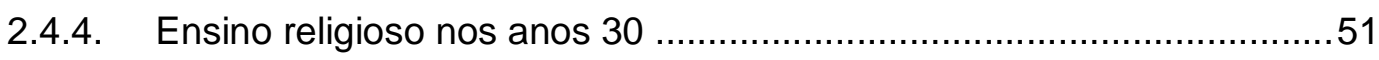

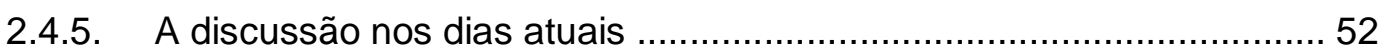

2.5. Para além do ensino religioso .................................................... 54

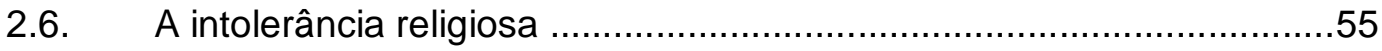

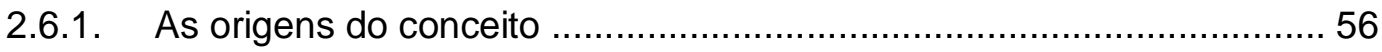

2.6.2. Impressões contemporâneas da tolerância .....................................61

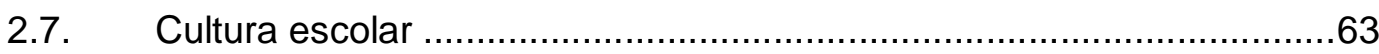

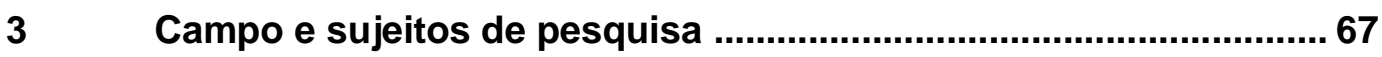

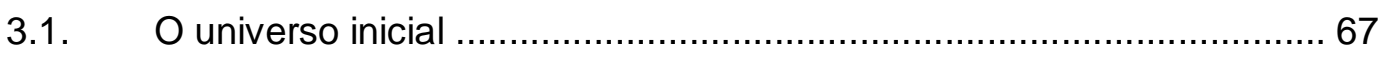

3.1.1. Descrição do perfil dos alunos .....................................................68

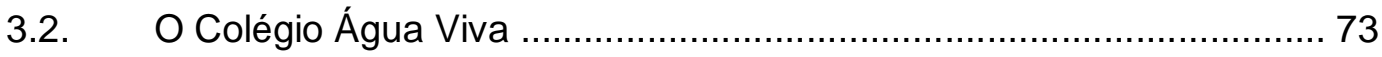

3.2.1. Os estudantes do Colégio Água Viva .............................................. 76

3.2.2. Os professores do Colégio Água Viva...............................................79 
$4 \quad$ Análise dos questionários dos alunos da escola Água Viva ......... 82

4.1. A construção do fator e a escolha da escola Água ............................. 82

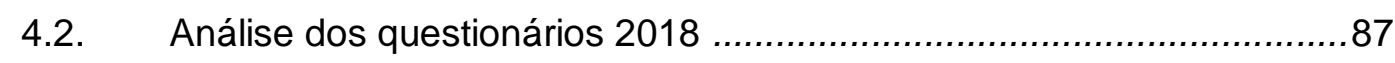

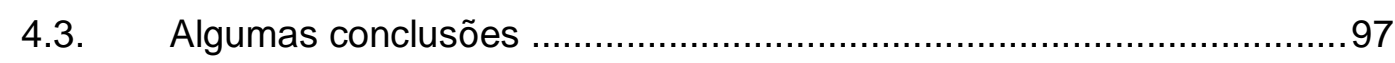

$5 \quad$ Análise dos dados qualitativos da escola Água Viva .................... 99

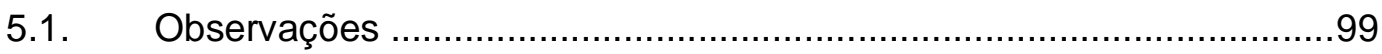

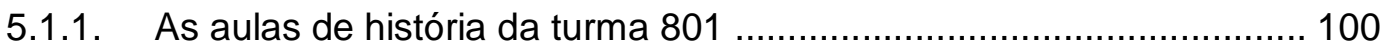

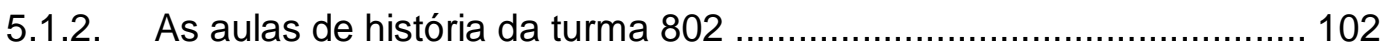

5.1.3. As aulas de ciências da turma 802 ................................................ 105

5.2. Análise das entrevistas ............................................................. 106

5.2.1. Entrevistas com professores e direção ..........................................107

5.2.1.1. A escola e a religião .................................................................109

5.2.2. Entrevistas com os alunos ....................................................... 115

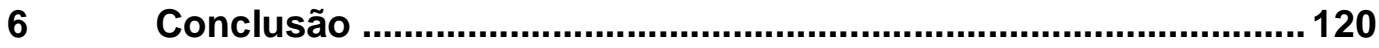

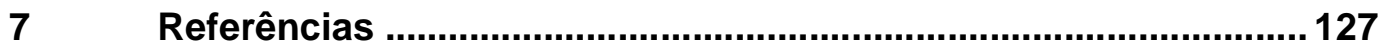

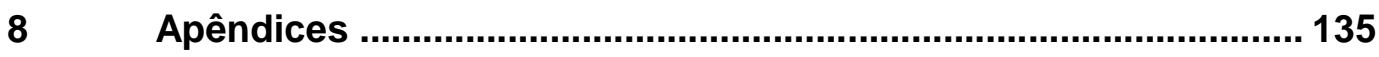

Apêndice 1: Roteiro de entrevista com professores .....................................135

Apêndice 2: Roteiro de entrevistas com alunos ............................................ 137

Apêndice 3: Termos de consentimento ......................................................... 138

Apêndice 4: Formulário de identificação dos professores ..............................140

Apêndice 5: Tabela com perfil dos professores ........................................... 142

Apêndice 6: Perfis dos alunos entrevistados ............................................. 143

Apêndice 7: Questionário aplicado aos alunos ........................................... 144 


\section{Lista de Tabelas}

Tabela 1.1 - Afirmativas sobre religião nos questionários 25

Tabela 2.1 - População total e grupos religiosos. Fonte: Jacob, Hees et al. (2013) IBGE, Censos Demográficos de 1980, 1991, 2000 e 2010 36

Tabela 3.1 - Distribuição de respondentes por escola 68

Tabela 3.2 - Idade dos alunos 70

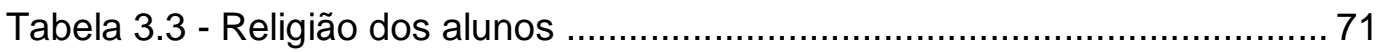

Tabela 3.4 - Frequência em templo religioso por religião .................................72

Tabela 3.5 - Distribuição dos estudantes do Água Viva participantes da pesquisa de acordo com o bairro em que residem

Tabela 3.6 - Distribuição dos estudantes pesquisados do Colégio Água

Viva de acordo com seus grupos religiosos

Tabela 3.7 - Sexo dos estudantes participantes da pesquisa no Colégio

Água Viva

Tabela 3.8 - Cor/raça dos estudantes participantes da pesquisa no

Colégio Água Viva

Tabela 3.9 - Idade dos estudantes participantes da pesquisa no

Colégio Água Viva

Tabela 4.1 - Construção do fator de comparação 83

Tabela 4.2 - Classificação das escolas segundo o fator gerado 84

Tabela 4.3 - Porcentagem de respostas à pergunta "Você já sofreu preconceito na escola por causa de sua religião ou por não te religião?"

Tabela 4.4 - Respostas ao questionário 2017

Tabela 4.5 - Respostas dos estudantes do colégio Água Viva ao questionário 2017

Tabela 4.6 - Respostas dos estudantes do colégio Água Viva ao questionário 2018

Tabela 4.7 - Respostas dos estudantes do 8 ano da escola Água Viva em 2018 para a afirmativa "Todas as pessoas têm que ter uma religião", de acordo com seus grupos de religião

Tabela 4.8 - Respostas dos estudantes do 8a ano da escola Água Viva em 2018 para a afirmativa " Quem não acredita em Deus vai para o inferno", por religião, de acordo com seus grupos de religião 
Tabela 4.9 - Respostas dos estudantes do 8o ano da escola Água Viva em 2018 para a afirmativa "Todos os evangélicos são fanáticos

(radicais, exagerados)", de acordo com seus grupos de religião

Tabela 4.10 - Respostas dos estudantes do 8ํano da escola Água Viva em 2018 para a afirmativa "O Candomblé é uma religião do demônio de acordo com seus grupos de religião

Tabela 4.11 - Respostas dos estudantes do 8o ano da escola Água Viva em 2018 para a afirmativa "Alunos de candomblé e umbanda podem usar suas guias (colares de santos) na escola", de acordo com seus grupos de religião

Tabela 4.12 - Respostas dos estudantes do $8^{\circ}$ ano da escola Água Viva em 2018 para a afirmativa "Alunos evangélicos podem fazer trabalhos escolares sobre religiões africanas", de acordo com seus grupos de religião

Tabela 4.13 - Respostas dos estudantes do 8a ano da escola Água Viva em 2018 para a afirmativa "É melhor acreditar na bíblia do que na ciência", de acordo com seus grupos de religião

Tabela 4.14 - Respostas dos estudantes do $8^{\circ}$ ano da escola Água Viva em 2018 para a afirmativa "Quem acredita em imagens de santos não vai para o céu, de acordo com seus grupos de religião

Tabela 4.15 - Respostas dos estudantes do $8^{\circ}$ ano da escola Água Viva em 2018 para a afirmativa "Só existe uma religião verdadeira" de acordo com seus grupos de religião

Tabela 4.16 - "É bom quando a professora reza na aula com os alunos", por religião

Tabela 4.17 - Respostas dos estudantes do $8^{\circ}$ ano da escola Água Viva em 2018 para a afirmativa "Já sofreu preconceito na escola por causa de sua religião, ou por não ter religião?"

Tabela 4.18 - Respostas dos estudantes do 8o ano da escola Água Viva em 2018 para a afirmativa "Já sofreu preconceito na escola por causa de sua religião, ou por não ter religião?”, de acordo com seus grupos de religião 96 


\section{Lista de Gráficos}

Gráfico 3.1 - Sexo dos alunos 69

Gráfico 3.2 - Raça dos alunos 69 


\section{Lista de siglas e abreviações}

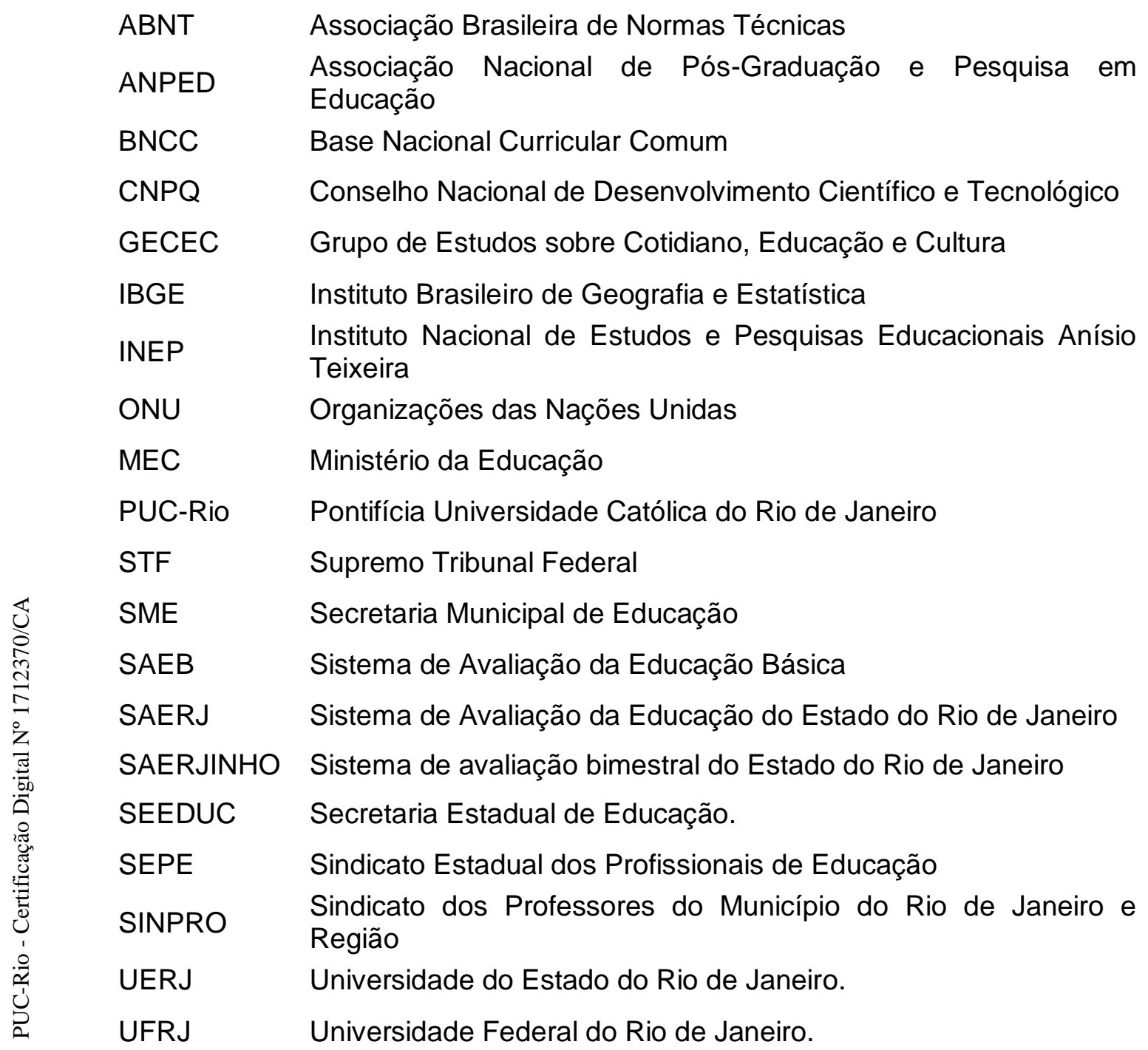




\section{1 \\ Introdução}

Passados séculos do Iluminismo e recorrentes anúncios de seu fim, a religião ainda é um poderoso instrumento de construção de identidade. Como nos mostra Setton (2008), a religião constrói significados, estruturas mentais e comportamentos. A religião também traz um caráter ideológico e político.

De acordo com Sanchis (1997), a religião dos brasileiros passou por uma série de transformações durante o século XX. A análise dos Censos Demográficos indica que a religião dos brasileiros vem se diversificando (JACOB ET AL, 2013). Há ainda um forte predomínio cristão, mas uma perda significativa da hegemonia católica. Além disso, é possível notar que a porcentagem de brasileiros que se declaram sem religião é de $8 \%$, o que equivalia a aproximadamente 15 milhões de pessoas à época do censo 2010. É importante notar que os autores tratam da categoria "sem religião", o que engloba não apenas ateus e agnósticos, mas também pessoas que não sei filiam a nenhuma instituição religiosa. Sendo assim, é possível notar que a maioria dos brasileiros se declaram religiosos, o que indica que a religião tem grande importância na formação da identidade e sociabilidade brasileira.

As identidades culturais são construídas a partir de múltiplas experiências, relações e espaços, incluindo a escola e seu cotidiano (CANDAU, 2011). A escola é um lugar de diversidade, com diferentes culturas, gêneros, religiões, orientações sexuais e etc.

Como nos mostra Candau (2011), as diferenças culturais - étnicas, de gênero, orientação sexual, religiosas, entre outras - se manifestam na sociedade como um todo. As questões colocadas são múltiplas, visibilizadas principalmente pelos movimentos sociais, que denunciam injustiças, desigualdades e discriminações, reivindicando igualdade de acesso a bens e serviços e reconhecimento político e cultural.

Essa diversidade se manifesta também no âmbito da educação. Se explicitam cada vez com maior força e desafiam visões e práticas profundamente arraigadas no cotidiano escolar. Candau alerta que a cultura escolar dominante nas instituições educativas, construída fundamentalmente a partir da matriz políticosocial e epistemológica da modernidade, prioriza o comum, o uniforme, o 
homogêneo, considerados como elementos constitutivos do universal. Nesta ótica, as diferenças são ignoradas ou consideradas um "problema" a resolver.

Para ilustrar aqui o que estamos falando, vamos apresentar dois casos recentes de relações escolares que o elemento religioso interferiu de forma decisiva.

O primeiro caso ${ }^{1}$, ocorrido em 2017, foi de uma aluna de 15 anos que cursava o $6^{\circ}$ ano em um colégio estadual de São Gonçalo. Candomblecista, ela foi alvo de ofensas por parte de outros estudantes em sala de aula. Ao ouvir provocações como "gorda macumbeira" e "macumbeiros têm que morrer", a vítima se levantou para discutir com os adolescentes e acabou sendo expulsa do recinto pela professora. De acordo com o pai da jovem, a aluna já vinha sofrendo bullying por causa da religião desde o início do ano, quando se matriculou na unidade. Após saber do episódio em que a filha foi expulsa de sala, o pai afirma ter solicitado à direção da escola uma reunião com os pais dos estudantes que a ofenderam, mas seu pedido não foi atendido.

O segundo caso $^{2}$ é de uma estudante que foi agredida por uma colega de turma, em uma escola estadual de Curitiba, por intolerância religiosa. A motivação para a agressão foi uma foto, postada no dia anterior em uma rede social, em que a menina aparece ao lado da mãe e de uma amiga, as três do Candomblé. No dia seguinte, uma colega disse que não queria ficar perto porque ela era "da macumba". A jovem candomblecista foi agredida pela colega e bateu com a cabeça em uma parede.

Entendemos que notícias de jornal apresentam uma versão parcial dos fatos não devemos entende-las como uma verdade inquestionável dos ocorridos. Nosso objetivo aqui, porém não é julgar os casos apresentados, mas apenas evidenciar a existência de relações conflituosas em relação à religião no contexto escolar.

Os casos relatados reforçam a hipótese de que a religião está presente na escola, em diferentes momentos do cotidiano escolar, independente da disciplina de ensino religioso. Casos assim podem ocorrer durante as atividades de aulas, bem como em momentos de lazer, alimentação, recreio ou no início das atividades escolares.

\footnotetext{
${ }^{1}$ Fonte: https://extra.globo.com/casos-de-policia/jovem-vitima-de-intolerancia-religiosa-dentrode-escola-em-sao-goncalo-21734126.html. Acesso em 28/05/2019

${ }^{2}$ Fonte: https://extra.globo.com/noticias/brasil/estudante-agredida-por-intolerancia-religiosadentro-de-escola-nao-quer-voltar-ao-colegio-17650415.html. Acesso em 28/05/2019
} 
As discussões em torno da laicidade do Estado e da disciplina de Ensino Religioso (CURY, 2004) e a intolerância às práticas religiosas não cristãs, principalmente as de matriz africana (QUINTANA, 2013), são influenciadas por preconceitos e disputas em torno dos objetivos da escolarização e dos valores a serem ensinados.

Nesse sentido, o presente trabalho visa abordar a relação entre o cotidiano escolar e a religião, investigando de que formas crenças religiosas podem fomentar ou se tornar alvo de ideias, expressões e práticas intolerantes por parte dos alunos.

Nesse contexto, interessa-nos pensar sobre a presença religiosa nas escolas. Nossa pesquisa se debruça, mais especificamente, sobre as concepções de alunos do $7^{\circ}$ ano de uma escola de ensino fundamental sobre religião, diversidade religiosa e como estas se relacionam com ideias tolerantes ou não.

\section{1. Justificativas}

A justificativa para essa pesquisa se dá em dois movimentos. O primeiro se dá a partir da minha trajetória pessoal e do porquê de eu ter chegado a esse campo de pesquisa. Já no segundo, argumentamos que esse trabalho explora uma dimensão ainda pouco estudada nas relações entre religião e escola

No âmbito pessoal, o meu interesse pela temática da religião na escola começou a partir da minha trajetória na graduação. Desde 2013 integro o GECEC, Grupo de Estudos sobre o Cotidiano Educação e Cultura(s). Nessa experiência tive a oportunidade de começar a notar as contradições que envolvem a presença da religião na escola assim como estudá-las de forma mais contundente.

Uma segunda razão pessoal para o estudo da temática é a minha experiência como professor, tanto como bolsista do PIBID de história, quanto como professor da escola básica. Nessas duas experiências pude ouvir muitas vezes expressões preconceituosas e intolerantes por parte dos alunos. Falas como "fulano é macumbeiro", "macumba é do diabo" "só existe um Deus", e algumas outras, foram bastante presentes. 
Em agosto de 2016 , comecei a dar aulas de história para o $6^{\circ}$ e o $7^{\circ}$ anos em uma pequena escola privada em Nova Iguaçu, na Baixada Fluminense. Localizada em uma região pobre da cidade, atende cerca de 190 alunos oriundos de famílias de baixa renda, moradores do seu entorno.

Em certa ocasião, quando trabalhava o conceito de politeísmo com uma turma de $6^{\circ}$ ano, dei uma aula sobre mitologia grega, explicando que esse povo acreditava em vários deuses. Apesar de alguns alunos já estarem familiarizados com a religião da Grécia Antiga, outros tiveram muita dificuldade em aceitar essa diferente concepção. Muitos alunos evangélicos disseram "mas só existe um Deus!". Mesmo quando explicado que aquilo era uma outra religião, que era diferente da deles, os alunos ridicularizavam a concepção grega.

Certa vez, dando aula sobre Egito antigo e sua religião politeísta, um grupo de alunos se revoltou alegando que "isso não era verdade" e que "apenas existia um Deus". Situações como essa, de dificuldade de compreender outras formas de se olhar o mundo, são constantes na minha experiência como professor de história. Quando se trata de abordar religiões de matriz africana o problema se acentua. Diversas vezes ouvi em sala de aula que estava falando sobre o "demônio". Alunos que são de religiões de matriz africana frequentemente sentem vergonha de se afirmarem como tal e, quando o fazem, são muitas vezes chamados de "macumbeiros" e "endemoniados".

Situações como essas - recorrentes ao longo de minha atividade profissional -, me fizeram atentar ainda mais para como a diferença religiosa é entendida por esses alunos e como eles percebem o "outro", o diferente de si. Esse fato relatado foi com uma religião que não tem mais fiéis no mundo contemporâneo. Porém, outras religiões, principalmente as de matriz africana, são constantes alvos de zombaria, como pode ser visto não só pela minha experiência pessoal.

A segunda parte da justificativa se constrói a partir de uma constatação inicial de uma lacuna no campo de pesquisa. Diversos autores investigam a presença da religião na escola, como Cunha (2011, 2012, 2006), Cury (2004), Caputo (2012), Cavaliere (2007), Fischman (2012). No entanto, grande parte das publicações acerca da relação entre religião e escola se debruçam sobre a presença da disciplina de ensino religioso na escola. 
Em uma busca na base de dados Scielo, por exemplo, ao ser pesquisado o termo "ensino religioso" foram encontrados 52 resultados. Já, ao procurar os termos "religião escola" não foi encontrado nenhum resultado.

Outro indício dessa preeminência das análises sobre ensino religioso no campo é a biblioteca do Observatório da Laicidade na Educação (OLÉ). O OLÉ é um grupo acadêmico, formado, gerido e financiado por uma rede de professores(as) e estudantes, militantes pró-laicidade do Estado, que elaboram, reúnem e difundem pela internet posições relacionadas especialmente à educação pública laica.

Nesse contexto, o OLÉ "propõe-se a identificar a presença de práticas religiosas nas escolas públicas tanto quanto a oposição a elas, compartilhar conhecimento e difundir posições políticas republicanas"3. Quanto às escolas não pertencentes às redes públicas de ensino, a posição do OLÉ é de respeito a suas opções filosóficas e/ou religiosas. Como é um grupo especializado no assunto, realizei uma busca em sua biblioteca digital ${ }^{4}$.

Em uma análise baseada nos títulos, dos 120 artigos presentes na biblioteca 32 explicitam o ensino religioso. O restante dos artigos apresenta análises históricas, reflexões teóricas sobre laicidade e reflexões sobre ensino de ciências. A partir apenas de uma análise dos títulos dos artigos, não identifiquei nenhuma pesquisa que falasse diretamente das concepções dos alunos em um contexto escolar. Em relação à biblioteca de teses e dissertações pude identificar que, de 2013 até 2017 foram produzidas 12 teses ou dissertações acerca do tema de interesse do observatório. Dessas, 2 falam acerca do ensino religioso, 1 sobre educação não formal, 1 sobre pós-graduação, 2 sobre legislação, 1 sobre religião no currículo. As 3 restantes foram trabalhos que se afinaram com o meu interesse de pesquisa a partir da leitura dos títulos e resumos. Dos trabalhos analisados, dois deles assumem a perspectiva dos professores, o que não é a minha abordagem.

Essa análise inicial da biblioteca do OLÉ indica que ainda há uma lacuna em relação às atitudes dos alunos no espaço escolar para além do ensino religioso. O que aponta, em minha avaliação, para a validade e relevância de minha investigação.

\footnotetext{
${ }^{3}$ Disponível em http://www.nepp-dh.ufrj.br/ole/ acesso em 06/12/2018

${ }^{4}$ Disponível no site http://www.edulaica.net.br/5/biblioteca/ (acesso em 26/10/2017).
} 
Em pesquisa anterior (RODRIGUES, 2016), realizada no colégio Menino Azul, uma escola pública, onde foram entrevistados três professores de história. Todos os entrevistados identificaram frequentes situações de preconceito no espaço escolar, não só o religioso, mas de todos os tipos. Em relação ao preconceito religioso, foi recorrente a indicação de que os praticantes de religiões de matriz afro são os que mais sofrem com esse tipo de atitude. Um dos professores, por exemplo, afirmou que:

"Já presenciei [preconceito em sala de aula] especialmente com a religiões de matriz afro, quando alguém manifesta. Eu já tive um aluno, até dessa escola, há uns dois anos atrás, Wellington, ele fez esse papel de iniciação, e eu escutava umas coisas. E mesmo quando eu tô falando "candomblé, umbanda" eles falam "ah, macumba", vem um risinho, um deboche, uma coisa que não é um coisa "é a escolha do outro", vem sempre com uma carga negativa ou, mesmo o riso, que é uma forma de não se aproximar daquilo, vêm com escárnio, vem com uma carga negativa".

É importante ressaltar que a pergunta foi "você já presenciou algum tipo de preconceito religioso no espaço escolar?". A intenção dessa pergunta era captar diferentes tipos de situação de preconceito religioso. A expectativa inicial, na verdade, era de que existissem outras situações, com expectativa forte com preconceito em relação à evangélicos, muitas vezes taxados de 'fanáticos'. Claro que havia a expectativa da existência de situações com religiões de matriz africana, até porque essas são, historicamente, práticas religiosas subalternizadas no Brasil, o que não era esperado era a sua exclusividade nas falas. Em nenhum momento na pergunta foram citadas especificamente as religiões afro-brasileiras e, como as entrevistas foram realizadas em momentos diferentes, individualmente, a reincidência da informação de que as crianças praticantes de religiões afrobrasileiras são vítimas de preconceito constantemente, na verdade a única situação citada, nos traz um dado importante

Além do demonstrado pelos estudos acadêmicos citados, as notícias abordadas na introdução desse trabalho também podem ser vistas como uma justificativa. Podemos acompanhar no noticiário, por exemplo, recorrentes formas intolerantes de se lidar com as diferentes concepções religiosas presentes no espaço escolar.

Ainda que o ensino religioso seja um elemento complicador para se discutir a experiência que tem sido vivida nas escolas, nosso objetivo aqui é investigar a presença da religião no cotidiano escolar, tendo em vista o relacionamento entre 
seus diferentes agentes e suas crenças religiosas. Mais especificamente buscamos entender como os alunos lidam com as diferentes religiões no contexto escolar e se há, e em que condições ocorrem conflitos, preconceitos e situações de intolerância religiosa.

\section{2. \\ Questões de pesquisa}

As nossas questões de pesquisa visam, portanto, entender melhor como a religião está presente no dia a dia da escola a partir das concepções dos alunos sobre a religião do outro, podendo ser resumidas da seguinte maneira:

- Como a diferença religiosa é entendida por esses alunos? Como eles encaram o outro, o diferente de si?

- Os fatores intraescolares, se as concepções e ações de professores e diretores influenciam na construção de concepções conflituosas e intolerantes?

A partir dessas questões procurei conhecer as concepções dos alunos, assim como investigar se a estrutura da escola, seu modo de agir influencia, ou não, nessas concepções em relação ao outro. Ou seja, investigar se o modo de funcionamento da escola, o clima, o trabalho realizado, as concepções de professores e direção sobre o assunto, poderia ser identificado como uma possível influência no comportamento dos alunos em relação à religião.

\section{3.}

\section{Objetivos}

Tomando como base as questões levantadas anteriormente, este trabalho teve como objetivos:

1) Identificar e analisar as relações, e os possíveis casos de conflitos e intolerância relacionados à religião no cotidiano escolar.

2) Analisar as concepções de alunos do $7^{\circ}$ ano de uma escola municipal do Rio de Janeiro sobre religião, diversidade religiosa e intolerância religiosa.

3) Compreender de que forma professores e gestores percebem a presença religiosa na escola e suas relações com a laicidade e a tolerância religiosa. 


\section{4 . Hipóteses}

A partir das considerações realizadas anteriormente, das questões levantadas e dos objetivos propostos sintetizamos nossas hipóteses de pesquisa.

- H1: A presença e discussão da religião no espaço escolar está envolta por diferentes constrangimentos, receio e dificuldades. Ou seja, o tratamento da religião no espaço escolar é uma questão tratada de forma diversa e alvo de dúvidas no espaço escolar.

- H2: Dentre os alunos do $7^{\circ}$ ano do ensino fundamental alguns alunos apresentam posições intolerantes acerca da religião. Ou seja, é possível que alguns alunos dentre os pesquisados apresentem visões desrespeitosas por religiões que não sejam as deles.

Cabe ressaltar que assumimos a posição de que as hipóteses em ciências humanas e sociais possuem um caráter de pressupostos dos quais o pesquisador inicia sua reflexão e pesquisa e, não necessariamente, se procura comprová-las.

\section{5 . Referenciais teórico-metodológicos}

A pesquisa foi realizada em duas grandes fases. A primeira fase ocorreu no ano de 2017, através da aplicação de questionários em turmas de $7^{\circ}$ ano de 10 escolas da Zona Sul do Rio de Janeiro. A segunda fase aconteceu no ano de 2018, aprofundando em uma das escolas da etapa anterior, denominada nesse trabalho de escola Água Viva.

Do ponto de vista metodológico, esta é uma pesquisa que se propõe trabalhar na articulação quanti-quali. Tal escolha se deu em função do problema apresentado e dos objetivos propostos, que se caracterizam por ser uma análise possível sobre as concepções de alunos do $7^{\circ}$ ano do ensino fundamental sobre religião e sua relação com o ambiente escolar.

O presente trabalho busca analisar como a religião está presente no contexto escolar. Essa pesquisa está vinculada a um projeto mais amplo do grupo de pesquisa GECEC, intitulado "Como preconceitos e discriminações impactam a aprendizagem? Um estudo longitudinal com estudantes do ensino fundamental”. Esse projeto inicial teve a pretensão de fazer um estudo longitudinal, partindo do 
$7^{\text {o }}$ ano do ensino fundamental, e acompanhando os mesmos sujeitos de pesquisa durante suas trajetórias no ensino fundamental II, do $7^{\circ}$ ao $9^{\circ}$ ano.

Segundo Lee (2010), este tipo de estudo visa analisar as variações nas características dos mesmos sujeitos amostrais durante um período de tempo não inferior a cinco anos. Os estudos longitudinais são tipicamente investigações que complementam outros tipos de pesquisa, tais como aquelas que se baseiam na análise da repetição de dados com diferentes sujeitos amostrais.

Para Bonamino e Oliveira (2012), os estudos longitudinais buscam entender o desenvolvimento dos dados sobre uma determinada problemática, considerando os mesmos sujeitos amostrais, ou seja, ao invés de comparar o resultado de uma medição com outra medição do mesmo padrão com sujeitos amostrais diferentes, os estudos longitudinais visam acompanhar os mesmos sujeitos buscando entender como o tema em investigação vai sofrendo modificações ao longo de um determinado período de tempo. Vale destacar que tal metodologia, ainda é pouco utilizada no campo educacional, mas vem sendo explorada em estudos no campo da psicologia, medicina e, até mesmo, em marketing, uma vez que se interessam pelos padrões de comportamento, consumo, de efeitos de medicamentos ou epidemiológicos ao longo dos anos.

A escolha pelo início do estudo no $7^{\circ}$ ano se deu, basicamente, por dois motivos. Primeiro, porque o sexto se caracteriza um ano atípico na vida dos estudantes, visto que é o período que eles precisam se adaptar ao sistema disciplinar com diferentes professores, instaurando um marco na trajetória acadêmica. Assim, o sexto ano foi descartado para o início do estudo longitudinal. Segundo, porque no sétimo ano os estudantes que ingressaram no segundo segmento do ensino fundamental estariam mais adaptados ao sistema disciplinar, mas também à própria escola, tendo em vista que, na região geográfica escolhida, há quatro escolas que possuem apenas o segundo segmento, matriculando estudantes que vêm de unidades que, por sua vez, atuam apenas com o primeiro segmento do ensino fundamental. Assim, segundo nossa hipótese, o sétimo ano demonstraria mais regularidade e o período de adaptação dos estudantes à escola já estaria superado.

O primeiro ano do estudo longitudinal do GECEC foi completo durante 2017. Para esta pesquisa, foram privilegiadas as escolas conveniadas ao Projeto Parceria, que envolve onze escolas públicas do entorno da PUC-Rio. Como são 
dez escolas municipais de ensino fundamental que fazem parte do projeto, foram essas as escolhidas para essa primeira parte da pesquisa.

A região geográfica das dez escolas são três bairros da Zona Sul da cidade do Rio de Janeiro, a saber: Gávea, Leblon e Jardim Botânico. Esta região, ainda que socialmente identificada como áreas nobres da cidade, possui grande concentração de grupos populares, oriundos, sobretudo, de grandes favelas, tais quais Rocinha, Vidigal e Cruzada São Sebastião, bem como do bairro do Horto, que apresenta concentração de uma classe média baixa, além de contingentes cada vez mais numerosos da Zona Oeste, principalmente Taquara, Jacarepaguá, Sulacap e Recreio.

Neste sentido, as dez escolas públicas, ainda que localizadas numa região nobre da cidade, registram, via de regra, matrículas que veem do seu entorno empobrecido. A opção por estas escolas deveu-se ao fato delas estarem no entorno da PUC-Rio, IES proponente do projeto de pesquisa, e por comporem o Projeto Parceria, que é um convênio celebrado entre a universidade e as direções dessas unidades escolares, contando, inclusive, com o apoio da Coordenação Central de Licenciaturas da universidade. O Projeto Parceria envolve atividades de estágio e pesquisa para os cursos de licenciaturas da PUC-Rio e a oferta de atividades formativas para os professores e estudantes das escolas conveniadas. Através da pesquisa de alguns pós-graduandos (CÂMARA, 2011; PINHO, 2011) e outras em andamento, podemos perceber que as escolas do Projeto Parceria vêm enfrentando as dificuldades que assolam a escola pública hoje, resistem como centros educacionais em busca da qualidade de ensino, atendendo cerca de 8.400 estudantes, e contam com o trabalho de aproximadamente 480 professores/as. O contato contínuo da equipe de pesquisa com as escolas pode ser visto como uma das vantagens deste projeto, já que esta rede de escolas tem sido um importante campo de estágio de licenciandos de diferentes cursos da PUC-Rio, bem como tem aberto suas portas para as pesquisas institucionais realizadas por mestrandos e doutorandos do Programa de Pós-Graduação em Educação.

Vale destacar que a realização de pesquisas nas escolas do Projeto Parceria obteve parecer positivo do Comitê de Ética da PUC-Rio e possui autorização da Secretaria Municipal de Educação (SME-RJ), Secretaria Estadual de Educação (SEEDUC-RJ) da direção das escolas, de professores para observação da sala de aula e dos responsáveis para realização de entrevistas e aplicação de questionários 
com os estudantes. Assim, o projeto prevê um espaço de controle externo das instituições envolvidas, o que nos garante uma investigação dentro dos marcos éticos e legais. As escolas pesquisadas nessa primeira onda foram nomeadas de acordo com obras da literatura brasileira, como forma de garantir seu anonimato: Colégio Água Viva, Colégio Hora da Estrela, Colégio Grande Sertão, Colégio Capitães de Areia, Colégio Iracema, Colégio Brás Cubas, Colégio O Quinze, Colégio Menino Azul, Colégio Auto da Compadecida e Colégio Vidas Secas.

Dessa forma, foi elaborado um questionário composto por diferentes questões que visavam, principalmente, captar concepções dos estudantes participantes sobre preconceitos com relação à religião, raça, gênero, sexualidade, deficiência, além de visões sobre bullying. Realizamos um pré-teste deste instrumento e, após revisão, uma nova versão foi aplicada em todas as turmas de $7^{\mathbf{o}}$ ano das escolas selecionadas. Após a tabulação dos dados, seu tratamento e análise em diferentes etapas utilizando-se o software SPSS, foi escolhida uma escola para a realização do presente trabalho.

A nossa pesquisa, portanto, se coloca como uma continuação da primeira onda em uma escala menor, em uma só escola, buscando as particularidades de sua realidade. Assim entre março e outubro de 2018 realizei observações do cotidiano dessa escola, assim como entrevistei professores, estudantes e membros da gestão a fim de aprofundar e detalhar os resultados e análises obtidos no questionário. Cabe destacar que, por motivos de força maior, a pesquisa longitudinal do GECEC teve de ser interrompida em 2017 e, portanto, para o ano de 2018 só contamos com dados da escola escolhida para o presente trabalho.

Essa pesquisa foi realizada através de uma abordagem quali-quanti, também conhecida como estudos mistos. Segundo Dal-Farra e Lopes (2013), os métodos mistos combinam os métodos predeterminados das pesquisas quantitativas com métodos emergentes das qualitativas, assim como questões abertas e fechadas, com formas múltiplas de dados contemplando muitas possibilidades, incluindo análises estatísticas e análises textuais. Para esses autores, os estudos quantitativos e qualitativos possuem, separadamente, aplicações muito profícuas e limitações conhecidas, por parte de quem os utiliza há longo tempo. Por esta razão, a construção de estudos com métodos mistos pode proporcionar investigações de grande relevância para o campo da pesquisa em Educação. Sob essa perspectiva, 
como procedimentos metodológicos foram utilizados a observação, o questionário e a entrevista.

\subsection{1.}

Questionários

Para uma primeira aproximação do campo e para a construção de um quadro mais amplo dos estudantes das escolas pesquisadas, optou-se pelo uso do questionário em uma abordagem quantitativa. A pesquisa quantitativa apresenta resultados que podem ser quantificados (dados numéricos, por exemplo), o que seria relevante para estudos com um número elevado de participantes.

Desta forma, os dados coletados, via de regra, são organizados e analisados por uma perspectiva estatística, sendo os resultados expostos em forma de gráficos, tabelas, etc. Segundo Fonseca (2002, p. 20):

"Diferentemente da pesquisa qualitativa, os resultados da pesquisa quantitativa podem ser quantificados. Como as amostras geralmente são grandes e consideradas representativas da população, os resultados são tomados como se constituíssem um retrato real de toda a população alvo da pesquisa. A pesquisa quantitativa se centra na objetividade [...].. A pesquisa quantitativa recorre à linguagem matemática para descrever as causas de um fenômeno, as relações entre variáveis, etc. A utilização conjunta da pesquisa qualitativa e quantitativa permite recolher mais informações do que se poderia conseguir isoladamente".

Segundo Malheiros (2011), a vantagem do questionário na pesquisa em educação é a possibilidade de um mapeamento em grande escala. Além disso, é possível trabalhar dessa forma com dados tabuláveis. Malheiros (2011) sublinha também a necessidade de um estudo-piloto, de uma testagem do instrumento de pesquisa para seu melhor uso.

Quanto ao uso de questionários, Simões e Pereira (2007) afirmam que uso da metodologia possibilita a investigação das relações causais, permitindo aos cientistas sociais não apenas descrever os fatos, mas também os entender as suas causas na análise da dinâmica social e política. Os autores afirmam que a elaboração de questões e a construção de um questionário devem ser guiadas não apenas pela experiência e intuição, mas também pela experimentação rigorosa. Eles afirmam a necessidade contínua de exercitar a "vigilância epistemológica", buscando detectar as possíveis fontes de produção de efeitos nas respostas (SIMÕES E PEREIRA, 2007, p. 243). 
A construção do questionário utilizado se deu em conjunto com o grupo de pesquisa GECEC. Devido ao fato de os interesses do grupo serem voltados às diferenças na escola em diferentes perspectivas, e não só quanto à questão religiosa, havia cinco temas principais no instrumento: religião, gênero/sexualidade, relações étnico-raciais, deficiência física/cognitiva e bullying. Pra fins dessa dissertação, foram consideradas prioritariamente as questões referentes à religião.

O questionário (Apêndice 7) foi estruturado em três partes. A primeira parte se constituiu por 50 afirmativas, sendo 10 para cada temática citada acima, para as quais os estudantes participantes deveriam se posicionar através de uma escala de Likert de quatro pontos (Discordo Muito, Discordo, Concordo e Concordo Muito). Tais afirmações expressavam, de diferentes maneiras, preconceitos ou estereótipos acerca das temáticas estudadas. As afirmativas sobre religião podem ser vistas na tabela 1.1 .

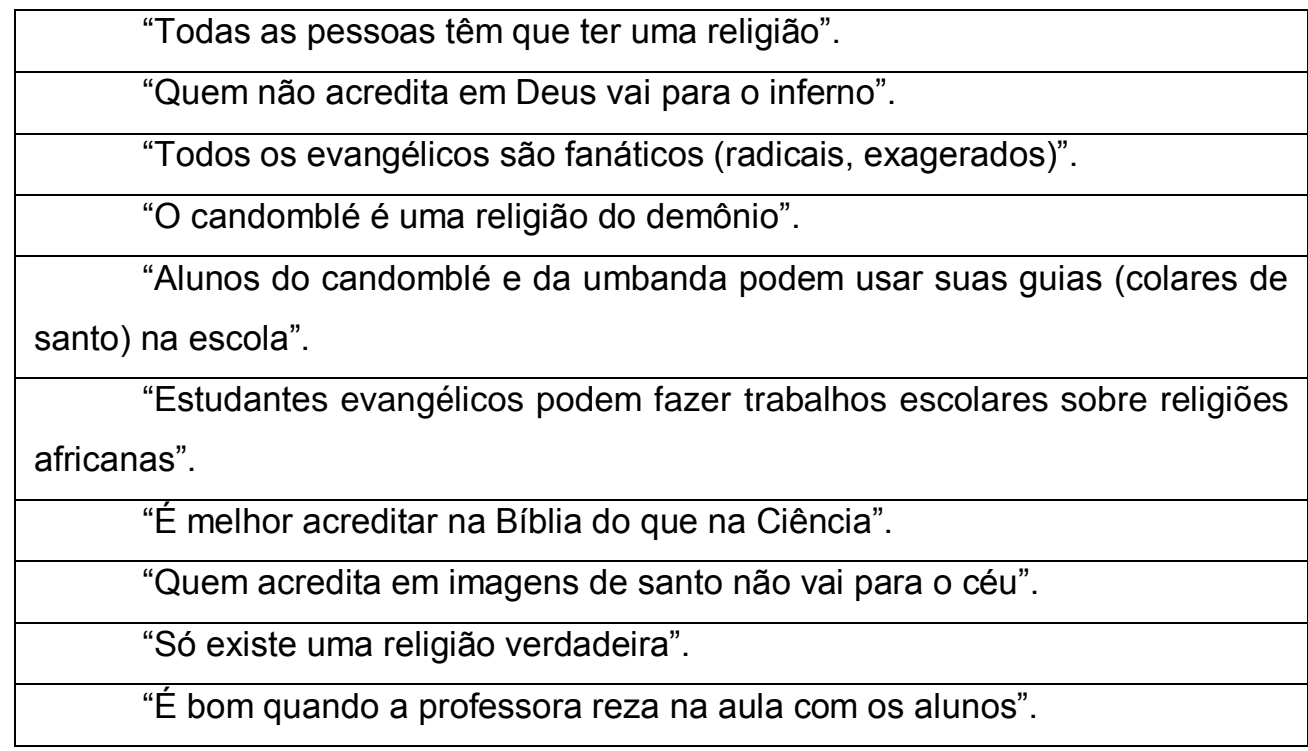

Tabela 1.1 - Afirmativas sobre religião nos questionários

Tais afirmativas tinham a intenção de entender como os alunos percebiam as religiões no espaço e escolar e também as suas concepções sobre os aspectos religiosos.

A segunda parte do questionário, da questão 51 até a 57, se debruçava sobre as experiências do aluno na escola. Diferente da primeira parte, que pedia a concordância, ou discordância, acerca de afirmativas, essa seção buscava saber 
informações sobre a experiência de preconceitos. O aluno poderia assinalar em 4 opções: Nunca, Poucas Vezes, Muitas Vezes e Sempre. A pergunta referente a religião foi a número 52, e perguntava: "Você já sofreu preconceito na escola por causa de sua religião ou por não ter religião?”. Essa seção tinha como objetivo perceber como os alunos se sentiam no ambiente escolar em relação a seus comportamentos.

Por fim, das questões 59 a 90, foram pedidos dados sociodemográficos dos alunos, como por exemplo, seu sexo, idade e sua religião. Essa parte teve como objetivo conhecer melhor o público dos questionários, assim como relacionar as respostas às perguntas das duas seções anteriores.

O questionário passou por uma etapa de validação de face, realizada por oito especialistas independentes, com pesquisas e experiência profissional relacionadas às diferentes temáticas pesquisadas. Após a construção de uma versão inicial, foi realizado o pré-teste em duas escolas de ensino fundamental da rede municipal do Rio de Janeiro, com o objetivo de aferir se a linguagem do questionário estava adequada e se era possível para alunos da faixa etária proposta pela pesquisa entenderem o que estava sendo perguntado. A testagem serviu de fundamentação para a realização de alterações na versão definitiva do questionário.

Após a criação da base de dados, utilizamos o software SPSS para o tratamento e análise dos dados. Inicialmente foram realizadas estatísticas descritivas para checagem de possíveis erros na tabulação e uma primeira aproximação dos dados. Em um segundo momento, foi realizada a análise fatorial exploratória de componentes principais com as afirmativas da primeira seção que envolviam a religião, com o objetivo de se formular um índice que representasse a intolerância religiosa expressa pelos estudantes em suas respostas ${ }^{5}$. No momento seguinte, comparamos as escolas com relação a esse índice a fim de identificar aquela de maior média. Isso nos permitiria, em princípio, estudar um campo com maior possibilidades de tensões e conflitos envolvendo a temática religiosa. Dessa maneira, foi escolhida a escola Água Viva.

Após essa escolha, partimos para a segunda fase da pesquisa, que envolveu três diferentes metodologias, a saber, a observação in loco, entrevistas, e reaplicação dos questionários com as turmas de $8^{\circ}$ ano de 2018 , que correspondem

\footnotetext{
${ }^{5}$ A construção desse índice será explicitada na análise dos questionários.
} 
às turmas do $7^{\circ}$ ano de 2017. É importante ressaltar que, no projeto inicial, não havia a intenção de repetir o questionário em 2018. No entanto, devido à dificuldade de conseguir entrevistar esses alunos, esse foi um caminho avaliado como alternativo para uma coleta de dados mais rica e uma consequente melhor compreensão da questão estudada. Temos a clareza que 2017 e 2018 contam com alunos diferentes e cenários diferentes

\subsection{2.}

Observação

Segundo Cardoso e Perin (2009), a observação como metodologia no contexto da pesquisa em educação vem de uma inspiração antropológica de um contato direto com o campo de pesquisa. No entanto, segundo os autores, a pesquisa de observação da sala de aula reserva algumas diferenças em relação a antropologia clássica. Na etnografia antropológica, por exemplo, é necessário que o pesquisador tenha um estranhamento em relação ao grupo por ele pesquisado. $\mathrm{O}$ pesquisador não deve estar familiarizado com os hábitos e atitudes do agrupamento humano em questão. Já na pesquisa de observação em sala de aula, geralmente são professores que também são pesquisadores, ou seja, há uma familiaridade com o "rito" da sala de aula, da educação formal. O estranhamento, no caso da observação da sala de aula, não é um elemento fundamental como é para os antropólogos. A comparação entre as diferentes experiências, a do dia a dia do professor/pesquisador em sua sala de aula, e realidade que ele se depara ao pesquisar uma sala de aula de outro professor, pode ser um elemento positivo para observações mais detalhadas a respeito da sala de aula.

Há, no entanto, elementos da pesquisa antropológica que também podem ser considerados como parte integrante do processo da pesquisa na educação. Podemos citar, como exemplo, a necessária construção de laços de confiança entre o pesquisador e os agentes da realidade pesquisada. Segundo Geertz (1978) é necessário conquistar a solidariedade e a camaradagem dos agentes que estão no campo. Isso acontece porque, em qualquer pesquisa de observação, o pesquisador se apresente como um elemento estranho aquele contexto. Mesmo no caso do professor pesquisando uma sala de aula, ele não faz parte do dia a dia daquela 
turma, das aulas daquele professor. Sabemos que uma sala de aula é um espaço reservado na relação entre professores e alunos. Segundo Fonseca (2010, p.390).

"A sala de aula é, por excelência, um espaço plural, coletivo, o palco no qual professores e alunos/atores/sujeitos vivem, aprendem, ensinam, relacionam-se uns com os outros, com o mundo, com os saberes. Ali eles se expressam, se expõem, se revelam, se colocam por inteiro, na totalidade. Objetividade e subjetividade, corpo e mente, razão e sensibilidade, o bio/psico/social em ação. Na sala de aula, o professor reconstrói sua biografia, sua história, sua trajetória, sua experiência pessoal e profissional. Espaço de aprender e ensinar, logo, um espaço, um campo de relações".

Sendo assim, ao entrar em um espaço de uma sala de aula, onde já estão estabelecidas suas regras, explícitas e implícitas de conduta, onde já existe um modo de operar por parte do professor e dos alunos, somos sujeitos estranhos naquele espaço. Por essa razão, entendo que a conquista da solidariedade e da camaradagem dos agentes no ambiente escolar é necessária. A conquista da confiança dos atores do campo, em particular da sala de aula, visa um "amortecimento" nesse estranhamento por parte do professor da turma. Segundo Cardoso e Perin (2009), uma estratégia possível para estabelecer essa relação de confiança é tentar estabelecer diretamente a relação com o professor da sala de aula, não fazer o contato através da direção da escola. Essa atitude pode evitar que a presença do pesquisador seja interpretada como uma imposição direta da direção ou da burocracia educacional. Esse cuidado visa a não rejeição pelo professor da observação do pesquisador em sua sala de aula.

Para Lüdke e André (1986), a observação permite chegar mais perto da perspectiva dos sujeitos de pesquisa. Além disso, são úteis para descobrir aspectos novos do problema. Ao entrar em uma sala de aula para observar, é possível que o que foi observado abra novas hipóteses e objetivos para a pesquisa.

Ao me aproximar dos professores que iria observar em sala de aula, busquei ter esse cuidado. No entanto, após a conversa inicial com a direção da escola, que foi bastante receptiva à pesquisa, procurei diretamente os professores que eu observaria. Tive o cuidado, a fim de conquistar a confiança, de me apresentar, além de pesquisador, como professor da rede pública também.

$\mathrm{Na}$ minha pesquisa in loco observei duas turmas de $8^{\circ}$ ano da escola Água Viva, uma no turno da manhã e outra à tarde. Foram feitas observações das aulas de ciências e de história, além dos momentos de entrada e do intervalo das turmas. A sala dos professores também foi foco de observação. Essas disciplinas foram 
escolhidas por abordar conteúdos que mais diretamente se relacionam a religião, como a Reforma Protestante e reprodução humana.

Uma das professoras de ciências apenas permitiu que eu observasse a aula dela sob a condição de que ela pudesse ver todas as minhas anotações do caderno de campo. Decidimos, por esse motivo, não acompanhar as aulas dessa professora e apenas entrevistá-la, visto que o caderno de campo diz respeito a observações pessoais do pesquisador, e sua divulgação para um agente da escola objeto da pesquisa poderia acarretar conflitos éticos no contexto da investigação. Sendo assim, acompanhei durantes seis meses as aulas de um professor de cada disciplina, durante 3 vezes na semana.

Além disso, o professor de história de ambas as turmas era o mesmo, tanto na tarde como na manhã. Dessa forma, acompanhei mais atentamente as duas turmas, 801 e 802, em suas aulas de história e ciências com dois professores diferentes. Portanto, a escola contava com duas turmas de $8^{\circ}$ ano, 801 de manhã e 802 à tarde. Foram observadas as aulas de dois professores, o de história das duas turmas e a de ciências da turma 802.

Assuntos como evolução, reprodução e até mesmo a discussão sobre corpo humano podem suscitar debates em sala de aula que mobilizem conceitos religiosos. Como nos indicam Teixeira e Andrade (2014), a história da relação entre o campo científico e o religioso está marcada por conflitos, diálogos, afastamentos e aproximações, e isso se reflete no ensino de ciências. Tanto professores como alunos têm suas crenças religiosas que em alguns casos podem entrar em conflito com o que é abordado pela disciplina.

$\mathrm{Na}$ disciplina de história também é possível identificar certos conteúdos que trazem debates acerca de conceitos religiosos. Estudos como de Oliva (2003), Flores (2006) e Laureano (2008) nos indicam que, principalmente em relação às religiões de matriz africana, existem situações de controvérsias durantes as aulas de história. Além das indicações acadêmicas, o acompanhamento das aulas de história também se deu por minha experiência pessoal. Sou professor de história há dois anos, tendo experiência em escola privada, de pequeno porte e em rede pública. Em ambas as experiências tive um alunado majoritariamente evangélico. Essa característica dos alunos levou a algumas situações de controvérsia religiosa em sala de aula. 
A aproximação dos professores, portanto, se deu com a tentativa de quebrar as barreiras naturais que se tem em relação ao pesquisador. No entanto, a tentativa de uma relação cordial para a quebra dessas barreiras não deve levar o pesquisador a reproduzir os discursos dos atores da sala de aula, segundo Cardoso e Perin (2009)

"Uma pesquisa de observação de sala de aula não precisa tem a pretensão de documentar ou resgatar documentadora de resgatar ou de preservar para a posteridade as falas dos professores. Ela também não precisa ter "aspirações democráticas" de incluir objetos tradicionalmente desprezados pela pesquisa social"

Quanto à possível generalização, os resultados de uma pesquisa de observação de sala de aula não dizem respeito a todos os professores e alunos. No entanto, mesmo que não possa ser generalizada para todos. A observação identifica fenômenos que não se encerram sobre os poucos atores observados na pesquisa.

\subsection{3.}

\section{Entrevistas}

A terceira metodologia de pesquisa foram as entrevistas com três professores, a diretora da escola e quatro alunos. Os três professores citados acima aceitaram conceder a entrevista, assim como a diretora da escola. No caso das entrevistas com os alunos, houve grande dificuldade para conseguir as autorizações dos responsáveis para a realização das entrevistas, o que limitou a quantidade de entrevistados

Segundo Duarte (2004), entrevistas são fundamentais quando se precisa/deseja mapear práticas, crenças, valores e sistemas classificatórios de universos sociais específicos, mais ou menos bem delimitados, em que os conflitos e contradições não estejam claramente explicitados. Para Lüdke e André (1986) a vantagem da entrevista como método de coleta de dados é que ela permite a captação imediata da informação desejada. O sujeito da pesquisa está na sua frente, à distância de uma pergunta

O tipo de entrevista utilizada foi a semiestruturada, uma técnica de coleta de dados que parte de uma conversa entre o pesquisador e o sujeito da pesquisa. $\mathrm{O}$ pesquisador dirige a entrevista de acordo com seus objetivos, baseando-se em um 
roteiro previamente elaborado, mas aberto às intercorrências do momento da entrevista, permitindo uma maior flexibilização na coleta de informações. Assim, as informações procuradas são aquelas que se inserem no contexto da pesquisa. Para Lüdke e André (1986), esse é o tipo de entrevista mais adequado nas pesquisas em educação, visto que as informações que se procura e os informantes que geralmente se quer contatar são mais convenientemente abordados através de um instrumento mais flexível.

Segundo Boni e Quaresma (2005, p.75):

"A interação entre o entrevistador e o entrevistado favorece as respostas espontâneas. Elas [as entrevistas semi-estrutiradas] também são possibilitadoras de uma abertura e proximidade maior entre entrevistador e entrevistado, o que permite ao entrevistador tocar em assuntos mais complexos e delicados, ou seja, quanto menos estruturada a entrevista maior será o favorecimento de uma troca mais afetiva entre as duas partes. Desse modo, estes tipos de entrevista colaboram muito na investigação dos aspectos afetivos e valorativos dos informantes que determinam significados pessoais de suas atitudes e comportamentos. As respostas espontâneas dos entrevistados e a maior liberdade que estes têm podem fazer surgir questões inesperadas ao entrevistador que poderão ser de grande utilidade em sua pesquisa."

Assim, a nossa opção por entrevistas semiestruturadas, nos permitiu ter, ao mesmo tempo, clareza dos nossos objetivos e flexibilidade para captar e explorar questões manifestadas pelos sujeitos de pesquisa não previstas anteriormente.

Há alguns procedimentos importantes a serem adotados na preparação de entrevistas para a análise. Primeiramente, as entrevistas devem ser transcritas, logo depois de encerradas, de preferência por quem as realiza. Em seguida, a deve-se realizar a conferência de fidedignidade: ouvir a gravação tendo o texto transcrito em mãos, acompanhando e conferindo cada frase, mudanças de entonação, interjeições, interrupções etc. Transcrever e ler cada entrevista realizada, antes de partir para a seguinte, ajuda a corrigir erros, a evitar respostas induzidas e a reavaliar os rumos da investigação.

Uma maneira de analisar é fragmentar o todo e reorganizar os fragmentos a partir de novos pressupostos. É possível dividir a fala dos entrevistados em "unidades de significação" e fazer uma análise minuciosa de interpretação dessas unidades para formular hipóteses para esclarecer o problema ou o universo estudado (DUARTE, 2004).

Nessa perspectiva, a interpretação exige que as unidades de significação (oriundas da fragmentação das entrevistas) sejam articuladas umas às outras a 
partir de categorias de análise: lembranças de escola, por exemplo, pode ser uma categoria de análise, assim como formação inicial, socialização profissional, gosto etc. Nesse caso, todas as unidades de texto retiradas das falas dos informantes que tiverem relação, por exemplo, com o indexador "lembranças de escola", deverão ser agrupadas sob esse indexador.

Os depoimentos coletados também podem, em muitos casos, refutar as ideias que o pesquisador tinha a respeito do problema antes de iniciar a pesquisa de campo. Por tudo isso, o fundamental é estar aberto às surpresas, ao imprevisível e ao imponderável que emergem do trabalho de campo, mesmo que isso nos obrigue a rever nossos conceitos e a refazer o caminho trilhado

Portanto, os dados de uma pesquisa desse tipo serão sempre resultado da ordenação do material empírico coletado/construído no trabalho de campo, que passa pela interpretação dos fragmentos dos discursos dos entrevistados, organizados em torno de categorias ou eixos temáticos, e do cruzamento desse material com as referências teórico/conceituais que orientam o olhar desse pesquisador. Isso implica a construção de um novo texto, que articula as falas dos diferentes informantes, promovendo uma espécie de "diálogo artificial” entre elas, aproximando respostas semelhantes, complementares ou divergentes de modo a identificar recorrências, concordâncias, contradições, divergências etc. Esse procedimento ajuda a compreender a natureza e a lógica das relações estabelecidas naquele contexto e o modo como os diferentes interlocutores percebem o problema com o qual ele está lidando.

Após a revisão das entrevistas, realizamos a análise de seu conteúdo, como proposto por Duarte. Foi realizada a busca por temas e categorias relacionadas aos objetivos da pesquisa, articulando categorias encontradas na bibliografia da área $\mathrm{e}$ também outras construídas a partir da fala dos entrevistados. Nesse processo, utilizamos o software de análise de dados qualitativos Atlas.TI para a criação de códigos. Estes foram checados entre as diferentes entrevistas, para assegurar sua consistência e evitar redundâncias ou ausências. Operando com esses códigos, organizamos categorias e temas que orientaram a interpretação dos dados e a escrita do texto.

O terceiro instrumento utilizado no ano de 2018 foi a reaplicação na escola Água Viva dos questionários utilizados nas turmas de $7^{\circ}$ ano de 2017. A decisão pela reaplicação do questionário se deu em função da dificuldade de se conseguir 
entrevistas com os estudantes. Assim, isso nos permitiu obter dados dos estudantes no mesmo ano das observações das aulas, além de permitir a comparação com dados do ano anterior. Tal comparação, contudo, deve ser feita com cautela, já que apenas parte dos alunos de 2017 estava presente novamente e refizeram os questionários.

Em conclusão, o cruzamento de diferentes metodologias - questionários, observações e entrevistas - nos permitem buscar articulações entre os dados construídos, prezando pelo rigor e coerência interna em sua análise.

\section{6.}

\section{Estrutura da dissertação}

A presente pesquisa de mestrado está organizada em seis capítulos, além de referências e anexos. Neste primeiro capítulo, optamos por fazer uma breve introdução da nossa temática e expor os elementos que acreditamos justificar a investigação, questões centrais de pesquisa, seus objetivos, hipóteses, escolhas metodológicas e características gerais.

No segundo capítulo, procuramos estabelecer diálogos com a literatura da área, explicitando os pressupostos da pesquisa e nossas perspectivas de análise. Neste sentido, serão apresentados e discutidos temas como o cenário religioso brasileiro atual, secularização, laicidade, ensino religioso, intolerância religiosa, escola no cotidiano escolar e cultura escolar.

No terceiro capítulo, descrevemos com maior profundidade o campo e os sujeitos de nossa pesquisa. São discutidos aspectos socioeconômicos e demográficos dos participantes do estudo, com especial atenção ao seu perfil religioso.

No quarto capítulo são analisados os dados quantitativos, principalmente através de estatísticas descritivas, comparações de médias e da construção do índice de intolerância religiosa.

No quinto capítulo serão feitas as análises das entrevistas e observações realizadas. Procuramos oferecer as linhas gerais dos contextos pesquisados, ressaltando, principalmente, os aspectos relacionados à presença religiosa nas escolas e como os participantes se relacionam com a religião. 
No sexto capítulo serão feitas as considerações finais. Nelas destacamos as conclusões de nosso trabalho e discutimos a validade das hipóteses levantadas, bem como em que medida nossos objetivos foram alcançados. 


\section{2 \\ Diálogos com a teoria}

No presente capítulo procuramos estabelecer diálogos com a literatura da área, explicitando os pressupostos da pesquisa e nossas perspectivas de análise. Neste sentido, serão apresentados e discutidos temas como o (i) cenário religioso brasileiro atual, (ii) secularização, (iii) laicidade, (iv) ensino religioso, (v) intolerância religiosa, (vi) a presença religiosa na escola para além do ensino religioso e (vii) cultura escolar.

\section{1.}

\section{O Cenário Religioso Brasileiro}

O censo demográfico realizado em 2010 pelo IBGE apontou a seguinte composição religiosa no Brasil: 64,6\% dos brasileiros (cerca de 123 milhões) declaram-se católicos; 22,2\% (cerca de 42,3 milhões) declaram-se protestantes (evangélicos tradicionais, pentecostais e neopentecostais e evangélicos nãodeterminados); 8,0\% (cerca de 15,3 milhões) declaram-se sem religião: ateus, agnósticos, ou deístas; 2,0\% (cerca de 3,8 milhões) declaram-se espíritas; 0,7\% (1,4 milhão) declaram-se as testemunhas de Jeová; 0,3\% (588 mil) declaram-se seguidores de religiões afro-brasileiras como o candomblé, o Tambor-de-mina, além da umbanda; $1,6 \%$ (3,1 milhões)

Por essas estatísticas apresentadas no censo de 2010 é possível notar que, além do alto percentual de cidadãos professos em alguma fé, entre as declaradas, as religiões cristãs, católica e evangélica, correspondem a quase $90 \%$ da opção dos brasileiros e apenas $8,0 \%$ se declaram sem religião ${ }^{6}$. Assim, pode-se afirmar que o cristianismo ainda faz parte da experiência social brasileira.

Como podemos visualizar na tabela 2.1, os católicos representavam, em 1980, 89\% da população do país. Os evangélicos de missão correspondiam a $3,4 \%$. Os evangélicos pentecostais eram 3.2\%, e os sem religião somavam 1,6\%.

Com o passar dos anos, podemos notar uma vertiginosa queda no número de católicos. Se em 1980 eram 89\%, em 2010 somavam 65 \%, uma queda de mais de 20 pontos percentuais. Esses dados corroboram o que nos aponta Pierucci (2006).

\footnotetext{
${ }^{6}$.É importante salientar, nesse caso, que o censo não diferencia os ateus daqueles que acreditam em Deus, mas não tem religião
} 
O autor mostra que, mesmo com toda a diversidade de religiões presentes no Brasil, há um forte predomínio do catolicismo e das igrejas evangélicas.

Já o número de evangélicos pentecostais apresenta um grande crescimento. Se em 1991 eles eram 5,6\%, em 2010 somavam 13,3\%, um crescimento de quase $10 \%$.

Percebe-se, ainda, o crescimento das religiões evangélicas pentecostais e neopentecostais. Conforme os Censos Demográficos do IBGE, os evangélicos perfaziam apenas 2,6\% da população brasileira na década de 1940. Avançaram para 3,4\% em 1950, 4\% em 1960, 5,2\% em 1970, 6,6\% em 1980, 9\% em 1991 e 15,4\% em 2000, ano em que somava 26.184.941 de pessoas, como mostra a tabela 2.1 .

\begin{tabular}{ccccccc}
\hline Anos & Católicos & $\begin{array}{c}\text { Evan- } \\
\text { gélicos } \\
\text { de } \\
\text { missão }\end{array}$ & $\begin{array}{c}\text { Evan- } \\
\text { gélicos } \\
\text { pente- } \\
\text { costais }\end{array}$ & $\begin{array}{c}\text { Evan- } \\
\text { gélicos } \\
\text { não } \\
\text { determi- } \\
\text { nados }\end{array}$ & Outros & $\begin{array}{c}\text { Sem } \\
\text { religião }\end{array}$ \\
\hline $\mathbf{1 9 8 0}$ & $89,0 \%$ & $3,4 \%$ & $3,2 \%$ & - & $2,8 \%$ & $1,6 \%$ \\
\hline $\mathbf{1 9 9 1}$ & $83,3 \%$ & $3,0 \%$ & $5,6 \%$ & $0,4 \%$ & $3,0 \%$ & $4,7 \%$ \\
$\mathbf{2 0 0 0}$ & $73,6 \%$ & $4,1 \%$ & $10,4 \%$ & $0,3 \%$ & $4,3 \%$ & $7,4 \%$ \\
$\mathbf{2 0 1 0}$ & $65,0 \%$ & $4,0 \%$ & $13,3 \%$ & $4,8 \%$ & $4,8 \%$ & $8,0 \%$ \\
\hline
\end{tabular}

Tabela 2.1 - População total e grupos religiosos. Fonte: Jacob, Hees et al. (2013) IBGE, Censos Demográficos de 1980, 1991, 2000 e 2010.

Segundo Mariano (2004), no Brasil, a expansão pentecostal não é recente nem episódica, ocorrendo de modo constante já há meio século, o que permitiu que o pentecostalismo se tornasse o segundo maior grupo religioso do país. Além disso, podemos notar uma intensa participação de políticos que pautam suas ações no parlamento através de suas convicções religiosas (LOCATELLI, 2014), o que demanda ainda mais a reflexão sobre a atuação da religião na sociedade.

Além do aumento dos evangélicos, é preciso analisar o aumento da população que se declara sem religião. É necessário salientar que esse grupo é heterogêneo. Segundo Teixeira (2016), não há nessa definição apenas ateus ou agnósticos. Mas também se enquadram aquelas pessoas que são religiosas, mas não pertencem a nenhuma instituição religiosa formal. Também se enquadram aquelas que creem em deus, deuses, energias, entre outros Segundo Jacob et al (2013): 
"O fato de um individuo se declarar sem religião não significa, ipso facto, que ele seja ateu. Apesar dessa tendência, não se deve desconhecer também a religiosidade do povo brasileiro, no sentido mais amplo do termo. Assim, sem dúvida, uma fração importante das pessoas que se dizem sem religião acredita em Deus, sem participar, no entanto, das instituições religiosas e sem se sentir pertencendo a uma comunidade confessional. Nesse sentido, mais do que o crescimento do ateísmo, trata-se, ao que tudo indica, de um enfraquecimento das religiões como instituições."

Como nos aponta Jacob et al (2013), no entanto, o crescimento pentecostal não acontece de maneira igual em todas as regiões. O crescimento se dá mais em áreas urbanas do que rurais, com destaque para as periferias de Rio de Janeiro e São Paulo. É possível observar também que nos locais onde crescem as igrejas pentecostais, há um decréscimo católico proporcional.

Segundo projeções de Alves et al (2017), a presença católica na população chegaria a 49,9\% em 2022 e a 38,6\% em 2032, enquanto a presença evangélica seria de $31,8 \%$ e $39,8 \%$, respectivamente. Ou seja, no ritmo atual da transição religiosa, não é improvável que os católicos representem menos de 50\% dos fiéis em 2022 e que sejam ultrapassados pelos evangélicos até 2032.

Como nos aponta Trevisan (2013), os evangélicos, além de crescerem em números e porcentagem na população brasileira, têm buscado uma maior presença na política institucional. A partir de 2003, com o crescimento demográfico dos evangélicos, há também um crescimento de políticos eleitos para a FPE (Frente Parlamentar Evangélica). Essa maior presença dos evangélicos na política brasileira acaba tensionando os sentidos de secularização e laicidade. Tais conceitos serão abordados na próxima seção.

\section{2. \\ Secularização}

A secularização é um conceito que extrapola a discussão sobre a escola. As reflexões sobre o conceito são realizadas por diferentes áreas do conhecimento, como a Sociologia, a Teologia, as Ciências Políticas, assim como a própria Educação. Segundo Outhwaite (1996), o conceito de secularização, definido de forma clássica, se refere ao processo através dos quais o pensamento, a prática e as instituições religiosas perdem seu significado social. Ou seja, o autor aponta 
que a secularização significa a perda de significados religiosos como organizadores da vida em sociedade.

O conceito de secularização é importante na discussão dessa pesquisa, pois só é possível pensar sobre a religião na escola, enquanto um espaço público, a partir da reflexão se a religião ainda é, ou não, um aspecto importante na compreensão das sociedades do século XXI.

A discussão sobre secularização é extensa e polêmica no meio da sociologia. O conceito clássico de secularização, que vem desde o iluminismo, no século XVIII, diz respeito à redução da atuação e da importância da religião na sociedade capitalista. Segundo Berger (2000) a ideia de secularização seria que a modernização leva necessariamente a um declínio da religião, tanto na sociedade como na mentalidade das pessoas. Essa forma de entender o processo vem passando por críticas e reformulações e é nessa discussão que vou me pautar.

Segundo Moniz (2017), ao se falar em teoria da secularização, estamos falando de concepções que designam, essencialmente, um conjunto de ideias que se referem à tensão entre modernização e religião. No essencial, essas teorias dizem que, à medida que os processos da modernização avançam, a tensão entre ambas tem como consequência a diminuição da relevância social da religião. Para o autor, as teorias da secularização afirmam que o processo de modernização e os seus subprocessos, transformadores da totalidade da estrutura social, não podem decorrer sem consequências para as tradições e instituições religiosas.

Segundo Casanova (2010), a narrativa europeia de secularização se remete às guerras religiosas do século XVII. O autor nos mostra, no entanto, que essa narrativa está equivocada. Para ele, as guerras religiosas do início da Era Moderna, especialmente a Guerra dos Trinta Anos, não produziram, pelo menos de imediato, um Estado secular, mas um Estado confessional. O Estado Católico espanhol sob os reis católicos serve como o primeiro modelo paradigmático de confessionalização do Estado e de territorialização religiosa. A expulsão dos judeus e muçulmanos espanhóis que se recusaram a se converter ao Catolicismo é a consequência lógica de tal dinâmica de formação do Estado.

A ideia de um estado secular veio mais tarde, apenas no século XVIII. Segundo Ferreira Neto (2012), apesar de ideias que remetem a separação das esferas políticas e religiosas existirem desde a antiguidade, é no século XVIII, com o pensamento iluminista, que os estados europeus modernos começam a se 
configurarem como seculares. De acordo com o autor, o projeto iluminista continha proposições e ambições específicas e originais. Entre elas o desenvolvimento de uma tendência crítica às realidades jurídicas fundadas em princípios exclusivamente religiosos. Para os pensadores iluministas do século XVIII, principalmente os seus ativistas mais radicais, como Diderot ou Holbach, a crítica a tal realidade jurídica de origem religiosa passava pela construção de uma nova civilidade, que erradicaria uma falsa consciência moral. Portanto, o projeto iluminista de estado do século XVIII, propunha uma radical separação entre igreja e estado.

No século XIX, o conceito de secularização é pensado com cada vez mais força. Nesse contexto, o pensamento de Weber é apontado como emblemático nessa discussão. Segundo Mariz (2003, p.73), Weber aponta a peculiaridade da racionalidade ocidental, como um processo constante de intelectualização e elaboração de regras. Mariz também destaca que, ao analisar a racionalização ocidental, Weber busca na no protestantismo, as suas raízes.

Segundo Montero (2009), o paradigma weberiano de secularização supõe que, no processo histórico de construção da modernidade, o Estado se tornaria cada vez menos acessível aos processos de moralização e a religião, desprovida de suas funções integradoras do passado, se deslocaria para o mundo privado, assentando sua plausibilidade não mais no poder político mas nas consciências individuais.

Para Pierucci, (1998), no entanto, as raras reflexões de Weber sobre o processo de secularização são mais uma constatação sobre seu tempo do que uma previsão. Segundo Pierucci (2003), há uma confusão teórica entre os conceitos de secularização e de desencantamento do mundo, o qual foi extensamente abordado por Weber. O conceito de desencantamento do mundo não se refere à saída da religião nas esferas privadas, mas sim a um processo interno das religiões, que abandonam gradativamente a mágica como seu significado e lançando mão da racionalidade em seu lugar. Na sua obra "Ética protestante e espírito capitalista" (1904), Weber mostra como a religião protestante passa por um processo de "desmagificação". De acordo com o sociólogo brasileiro, há uma confusão conceitual ao se atribuir a Weber a previsão de um estado secular: 
"É básico para um cientista social que se pretende especializar no estudo das religiões entender, por exemplo, que desencantamento em sentido técnico não significa perda para a religião nem perda de religião, como a secularização, do mesmo modo que o eventual incremento da religiosidade não implica automaticamente o conceito de reencantamento, já que desencantamento em Weber significa um triunfo da racionalização religiosa.” (PIERUCCI, 2003, p. 120)

Moniz (2017) nos indica que a tese weberiana é de que a Reforma Protestante, o Iluminismo e a Industrialização desenvolveram uma perspectiva racional do mundo - baseada em padrões empíricos de prova, conhecimento científico dos fenômenos naturais e domínio tecnológico do universo - que fez crescer uma cosmovisão racional que, por sua vez, enfraqueceu as fundações da crença no sobrenatural.

Diversos autores vêm estudando, portanto, esse processo de "afastamento" da religião do mundo. Um dos mais importantes é Peter Berger, para quem a secularização, que está na base da formação de uma situação de pluralismo, é definida como "o processo pelo qual se suprime o domínio das instituições e os símbolos religiosos de alguns setores da sociedade e da cultura" (BERGER, 1985, p. 119). O resultado mais evidente desse processo seria a crise de credibilidade das religiões, tanto na realidade objetiva quanto na consciência dos homens. Segundo o autor, a secularização colocou uma situação nova para o homem moderno. Pela primeira vez "as legitimações religiosas do mundo perderam sua plausibilidade não apenas para poucos intelectuais e outros indivíduos marginais, mas para amplas massas de sociedades inteiras" (BERGER, 1985, p. 137). O autor busca as raízes desse processo ocidental justamente nas suas origens religiosas. Segundo Berger, desde a origem do cristianismo, tendo seu ápice no protestantismo, há uma tendência para um mundo secular.

A tese da secularização passou por algumas controvérsias no decorrer dos anos. Segundo Mariano (2011). A partir da emergência de grupos religiosos na esfera pública e do crescimento vertiginoso de novos movimentos religiosos e de religiões mágicas e fundamentalistas em quase todas as regiões do planeta nas últimas décadas, provocou a rediscussão de seus pressupostos e perspectivas sobre o presente e o futuro.

Berger (2000) faz uma reflexão sobre sua própria teoria pregressa. O autor afirma que em seus primeiros trabalhos acreditava que, com o tempo, a religião perderia sua influência no mundo, restringindo-se a uma esfera própria, à parte da 
política, das artes, da produção de conhecimento, etc. Esse fenômeno atingiria não só a esfera estatal, a fronteira entre o público e o privado, mas também a própria crença pessoal do ser humano.

Berger (2000) argumenta, no entanto, que a suposição de que vivemos em um mundo secularizado é falsa e que o mundo continua tão religioso como sempre foi. Berger mostra que a modernidade gerou sim efeitos secularizantes em algumas partes do mundo, mas gerou também o que chama de dessecularização. $\mathrm{Ou}$ seja, as crenças e práticas religiosas continuaram na vida das pessoas e as instituições religiosas provocam ainda grande influência política, econômica e social.

Cecília Mariz (2000) critica Berger afirmando que apesar de negar uma teoria da secularização simples e mecânica, o autor não rejeita a secularização como tal. Reconhece-a como uma dimensão que marca a sociedade contemporânea, mas sublinha seus limites, destacando ainda que esse processo pode gerar o seu oposto. Mariz discorda do termo dessecularização usado por Berger, já que para ela, o conceito deveria ser reservado apenas para situações onde uma secularização, efetivada de fato, tivesse sido revertida. Dessa forma Mariz afirma que nenhum dos autores clássicos, Weber, Durkheim ou Marx acreditava no fim da religião na esfera pessoal e até mesmo pública. Segundo ela, todos os autores acreditavam em uma desilusão com as ideias iluministas.

Em uma perspectiva distinta, Pierucci defende que há um engano na sociologia da religião ao considerar a "revanche de Deus" (PIERUCCI, 1997, p.100), ou seja, uma volta da religião para o mundo.

Já Casanova (2011) argumenta que a secularização deve ser percebida sobre 3 subteses: (a) A teoria da diferenciação institucional das chamadas esferas seculares, tais como Estado, economia, ciência, instituições religiosas e normas; (b) A teoria do progressivo declínio das crenças e práticas religiosas, em conformidade aos níveis de modernização; (c) A teoria da privatização da religião como uma precondição da modernidade secular e das políticas democráticas.

Dessas três subteses, afirma que atualmente se sustenta apenas a primeira, dado que o fenômeno da pluralidade religiosa e da recomposição das religiões em face da emancipação das esferas sociais dos Estados modernos seria o inverso da completa separação entre a religião (destinada à esfera privada) e o Estado (na 
atribuição de gerente do público). Ou seja, há uma posição de recomposição religiosa.

Casanova (2011) sugere, portanto, que a secularização deve ser pensada como um fenômeno triplo: o declínio da religião, a diferenciação das esferas seculares, e a privatização da religião. E propõe que pensemos sobre a existência não de uma, mas de múltiplas modernidades, que podem levar a diferentes aproximações entre modernidade e secularismo. Na medida em que o alarmado declínio não aconteceu e, ao contrário, até prosperou em alguns contextos, podemos estar diante de uma nova semântica da religião na sociedade.

Outro autor que se debruça sobre a tese da secularização é Habermas. Segundo Harbermas (2013), o processo de secularização moderno inclui uma série de fenômenos. No centro, encontra-se a emancipação da esfera mundana em relação ao domínio religioso. Política, economia, direito, ciência, educação, arte, etc. se separam cada vez mais dos impedimentos e do controle da religião e se desenvolvem de acordo com uma lógica própria. Deste modo, a religião é cada vez mais empurrada para fora da esfera pública social, isto é, para o âmbito privado - com a consequência de que as convicções religiosas começam a erodir e seu legado, cada vez mais frequentemente, a não ter sucesso. A isto corresponde o declínio da influência da Igreja, tanto na sociedade quanto em relação à conduta dos indivíduos. Originalmente, esse enfraquecimento da Igreja [Entkirchlichung] começara com aquilo que o conceito de secularização designa no âmbito jurídico: a transferência forçada de bens de propriedade da Igreja para o Estado.

Benefícios consideráveis estão ligados a este processo de secularização. Isso inclui um aumento significativo no espaço de liberdade individual, como resultado do declínio da influência da Igreja, assim como a enorme ampliação do conhecimento de uma ciência independente das restrições impostas pelas visões de mundo, ou a difundida contenção de conflitos religiosamente motivados, através da mediação do Estado secular e de um correspondente sistema jurídico. Estes ganhos inegáveis não raro nutriram a convicção de que o processo de secularização seria uma progressão linear, conduzida inexoravelmente desde a escuridão de circunstâncias não esclarecidas em direção à clara luz de uma civilização determinada pelo pensamento científico, pelas inovações e facilitações técnicas e por um estilo de vida liberal, como nos mostra Berger (1985). 
A religião, segundo a expectativa de muitos, seria, desta forma, cada vez mais marginalizada, ou quem sabe até mesmo desaparecesse completamente. Mas foi exatamente isso que não aconteceu. Antes, a religião persiste também em contextos seculares de vida. Hoje, constatamos uma nova atenção voltada para a religião: não só na esfera da vida privada, mas especialmente também na esfera pública social. É no interior desse contexto que Habermas (2013) fala de uma sociedade pós-secular. A esse contexto subjaz a observação de que a relação da sociedade secularizada com a religião mudou, e que vem à tona uma forma nova e modificada de tensão entre ambas.

Dessa forma, podemos nos perguntar se a escola, como uma instância da modernidade, é um lugar secular, a religião está presente nesse ambiente? Como a religião está presente no dia a dia da escola? No entanto, para refletirmos mais sobre essas indagações, veremos na próxima seção o conceito de laicidade.

\section{3. Laicidade}

A expressão "laicidade" deriva do termo laico ou leigo. Etimologicamente laico se origina do grego primitivo laós, que significa povo ou gente do povo. De laós deriva apalavra grega laikós de onde surgiu o termo latino laicus. Os termoslaico, leigo exprimem uma oposição ao religioso, àquilo que é clerical (RANQUETAT Jr, 2008). Para Mariano (2011, p.244) "a noção de laicidade, de modo sucinto, recobre especificamente à regulação política, jurídica e institucional das relações entre religião e política, igreja e Estado em contextos pluralistas."

Diferente do conceito de secularização, que se refere a uma racionalidade que a modernidade traz, o conceito de laicidade abarca aquilo que não é religioso. É uma condição do Estado moderno (RANQUETAT JR, 2008). Mais do que a discussão sobre secularidade, se a religião ainda tem importância significativa no mundo ou não, a laicidade se refere à não interferência de valores e dogmas religiosos na esfera do Estado. Para Blancarte (2008, p.20), 
A laicidade, assim como a democracia, é mais um processo do que uma forma fixa ou acabada em forma definitiva. Da mesma forma que não existe um estado absolutamente democrático, também não existe um sistema político total $\mathrm{e}$ definitivamente laico. (Blancarte, 2008, p. 20)

No entanto, para Sarmento(2007), ainda que guarde diferenças semânticas e históricas, a laicidade está fortemente condicionada pelo surgimento da ideia de secularização. Os autores argumentam que, em alguns países como por exemplo França e EUA, a laicidade foi criada como uma com doutrina de não interferência entre as esferas do Estado e da igreja.

Segundo Ranquetat Jr (2008), A laicidade é uma noção que possui caráter negativo, restritivo. Sucintamente pode ser compreendida como a exclusão ou ausência da religião da esfera pública. A laicidade implica a neutralidade do Estado em matéria religiosa.

Andrade e Teixeira (2014) argumentam que a laicidade atua em duas direções. Por um lado, a religião privada é protegida da censura e da interferência do Estado. Por outro lado, o Estado deve ser protegido da interferência religiosa em suas decisões, suas leis. Os valores e justificativas das ações estatais não devem ser balizado por valores razões religiosas.

Sendo assim, há uma esfera jurídica e uma esfera prática quando se fala de laicidade. Como mostra Cury (2004), no caso brasileiro, a constituição de 1824 já garantia expressamente a liberdade de cultos. No entanto, o Estado imperial era oficialmente católico, não oficialmente laico.

O Brasil é considerado, atualmente, um Estado laico em virtude de dispositivos constitucionais que amparam a liberdade de religião. Assim, o artigo $5^{\circ}$, inciso VI, e o artigo $19^{\circ}$, inciso I da Constituição Federal dispõem:

Art. $5^{\circ}[\ldots]$

VI - é inviolável a liberdade de consciência e de crença, sendo assegurado o livre exercício dos cultos religiosos e garantida, na forma da lei, a proteção aos locais de culto e suas liturgias.

Em sequência, cita-se o artigo 19, I, da Constituição mencionada:

Art. 19. É vedado à União, aos Estados, ao Distrito Federal e aos Municípios:

I - estabelecer cultos religiosos ou igrejas, subvenciona-los, embaraçar-lhes o funcionamento ou manter com eles ou seus representantes relações de dependência ou aliança, ressalvada, na forma da lei, a colaboração de interesse público.

Como já mencionado, a laicidade era um dos principais valores republicanos na época da proclamação. O que faz, oficialmente, o país laico desde 1890. 
No entanto, a discussão se esse estatuto jurídico se apresenta na prática, é fruto de controvérsias. Segundo Ricardo Mariano (2011) a laicidade não é, e nunca foi, um valor central na República brasileira. Para o autor, na prática, nunca houve neutralidade religiosa no Estado brasileiro. Mariano argumenta que a igreja católica manteve privilégios de tratamento pelo Estado.

As religiões de matriz africana, historicamente subalternizadas e discriminadas no contexto brasileiro, Oro (2011) e Mariano (2011) mostram que o direito à liberdade religiosa inscrito nas Constituições nem sempre esteve presente em diversos contextos religiosos. Perpetuaram-se as perseguições às religiões não católicas,

Segundo Sofiati (2015), em um contexto de pluralismo religioso, ou de diversidade cristã, conforme o caso brasileiro, a principal forma de influência da religião no Estado é por meio da ação política a partir das regras da democracia. Em sua visão, a influência das religiões pentecostais no congresso nacional vem comprometendo a laicidade no Brasil. Para Mariano (2011, p. 254).

\begin{abstract}
"A laicidade estatal no Brasil não somente não dispõe de força normativa e ascendência cultural para promover a secularização da sociedade e para assegurar sua própria reprodução, como tem sido acuada pelo avanço de grupos católicos e evangélicos politicamente organizados e mobilizados para intervir na esfera pública. Dotadas de elevado poder religioso, econômico, midiático e político, tais instituições religiosas, na avaliação de Pierucci (1997, p. 277; 287), 'gozam de situação legal francamente privilegiada' e conseguem volta e meia, através de seus lobbies e de sua representação parlamentar, forçar 'uma insuportável capitulação do poder público'."
\end{abstract}

Há, na verdade, uma disputa pelo conceito de laicidade entre os políticos religiosos e os laicos (Mariano,2011; Trevisan,2013). Os políticos laicos defendem que a laicidade se refere à não interferência religiosa nas questões do Estado. Já os políticos religiosos, se amparam em uma definição de laicidade como a liberdade de todas as religiões interferirem no país. Argumentam que o Estado é laico, não ateu. No entanto, como mostra a citação de Mariano (2011) referenciada acima, as religiões que tem capital político e, principalmente, eleitoral, são as religiões cristão majoritárias. Tal contexto gera um desequilíbrio de forças, e mostra a fragilidade do argumento. Por último, é importante salientar que tanto secularização, como laicidade são processos que se desenrolam em contextos específicos. Para Oro (2011), a laicidade como instrumento jurídico legal definido pelo Estado, não se confunde com a liberdade religiosa, o pluralismo e a tolerância. Para o autor, é possível ter esses três elementos em um 
Estado não oficialmente laico, como é o caso da Grã-Bretanha e dos países escandinavos.

É importante entender que tanto a secularização assim como a laicidade são processos que aconteceram em um contexto da modernidade ocidental. Dessa forma, não é possível universalizar esses fenômenos, e nem considerá-los como uma evolução, no sentido positivista da palavra. Cada país possui um conjunto de características e circunstâncias sociais e culturais que possibilitam formas variadas e peculiares de laicidade e secularização. Desta maneira podemos falar em uma laicidade francesa, de uma norte-americana, uma brasileira, e assim por diante (ORO, 2011).

Enquanto nos Estados Unidos o processo de laicização ocorreu de forma quase pacífica e rapidamente com a consagração da separação entre o Estado e as igrejas na primeira emenda de 1791, na França o processo foi progressivo, tortuoso e conflitivo. Iniciado com a revolução francesa em 1789, afirma a liberdade de consciência e a liberdade de cultos em 1791. Depois de quase um século de regime concordatário, que preserva os vínculos entre o Estado e as religiões, a separação se dá finalmente em 1905, após muitas lutas, tensões e discussões (ORO, 2011).

Além da política, a laicidade é polêmica em relação a escola. Nas próximas seções iremos abordar com essa questão pode ser refletida no contexto escolar.

\section{4. O Ensino Religioso}

A relação entre religião e escola pública no Brasil não vem de hoje. Desde o século XIX, com as ideias positivistas e republicanas no contexto brasileiro, intelectuais e a população civil contestam a forte relação, até então institucional, entre a religião e a educação.

O primeiro tópico a ser discutido sobre esse aspecto é a presença do ensino religioso na escola pública. A existência dessa disciplina é a mais evidente controvérsia acerca dessa relação.

Primeiro ponto importante é compreendermos que o aspecto religioso nunca deixou de ser um elemento presente na educação formal brasileira. Como nos indica Carlos Roberto Cury (2004 página 183): 
"O ensino religioso é mais do que aparenta ser, isto é, um componente curricular em escolas. Por trás dele se oculta uma dialética entre secularização e laicidade no interior de contextos históricos e culturais precisos"

Para desenvolver uma reflexão sobre uma educação que envolva a presença da religião no espaço escolar é inescapável observar essa questão em uma perspectiva histórica. Compreender a situação atual implica numa avaliação histórica dessa relação.

\subsection{1.}

\section{Ensino e religião na Colônia}

Tradicionalmente se estabelece a chegada dos primeiros jesuítas, em 1549, como marco para a história da educação na América Portuguesa. Os religiosos da Companhia de Jesus chegam ao Brasil com o objetivo de converter os índios ao cristianismo, tornando-se peças fundamentais no processo de conquista e catequese dos índios, como pretendido pela Coroa portuguesa na colonização. Cabe destacar que, com o desejo de propagar a fé católica, os religiosos ensinam aos nativos saberes básicos, como ler e contar.

Entretanto, assumem também a educação dos colonizadores e colonos, numa sintonia de interesses da Coroa portuguesa e das práticas específicas daquela ordem, que incorporou a educação e a criação de colégios como uma estratégia evangelizadora em todos os lugares onde atuou. No Brasil, o primeiro colégio foi criado na Bahia em 1564, ao qual seguiram em 1585, os de Olinda e Rio de Janeiro. Esses colégios, mais estruturados que as escolas de meninos, eram internos e recebiam órfãos portugueses e filhos da elite colonial. As escolas e colégios jesuítas, subsidiados pelo Estado português, se obrigavam a formar gratuitamente sacerdotes para a catequese, instruir e educar os indígenas, os mamelucos e os filhos dos colonos brancos. O estudo, nesse contexto, é encarado como fundamental, um espaço para a guerra de ideias contra o protestantismo e na preservação dos valores morais e na difusão da cultura católica europeia.

Segundo Paulo Ribeiro (1993)

"O principal objetivo da Companhia de Jesus era o de recrutar fiéis e servidores. A catequese assegurou a conversão da população indígena à fé católica e sua passividade aos senhores brancos. A educação elementar foi inicialmente formada para os curumins, mais tarde estendeu-se aos filhos dos colonos." 
Podemos ver assim que, o início de uma concepção de educação na América Portuguesa se vincula diretamente à ideia da catequese e do catolicismo. Em 1759, o constante conflito entre o poder real e os jesuítas levou o Marquês de Pombal a expulsá-los de Portugal e de suas colônias sob a alegação de que a Companhia de Jesus se transformara em um verdadeiro Estado dentro do Estado português. A partir de então, oficialmente, é instituído o ensino laico e público através das cartas régias. Era de se esperar então que o ensino se desvincularia gradativamente de seu aspecto religioso, mas não é o que propriamente ocorre.

\subsection{2.}

\section{Ensino e religião depois dos jesuítas: Império}

Mesmo após a expulsão dos jesuítas e da independência, mantém-se o regime do Padroado $^{7}$ e a religião Católica Apostólica Romana é afirmada como religião oficial do país na Constituição de 1824. Segundo Cury, nesse período, tem-se a primeira manifestação do ensino religioso no interior de uma lei relativa à educação escolar, que é dada no ano de 1827 (CURY, 1993). Nela está explicitado que os professores deveriam ensinar a ler e a escrever, as quatro operações da aritmética e os princípios de moral cristã e da doutrina da igreja católica romana.

Essa lei, que manda criar escolas de "primeiras letras em todas as cidades, villas e lugares mais populosos do Império", destinava a regulamentar o inciso 32 do art. 179 da Constituição Imperial.(BRASIL, 1827)

Seu art $6^{\circ}$ diz o seguinte que os professores deverão ensinar a doutrina da religião católica.

Mesmo com as reformas pombalinas na educação e com a expulsão dos jesuítas, a religião católica continua, através do regime do Padroado, sendo uma presença primordial na política imperial e continua presente como uma forma de

\footnotetext{
7 Segundo OLIVEIRA (2008). Padroado pode ser definido como " Um sistema onde a Igreja delegava aos monarcas dos reinos ibéricos a administração e a organização da Igreja Católica em seus domínios. O rei mandava construir igrejas, nomeava os padres e os bispos, sendo estes depois aprovados pelo Papa. Assim, a estrutura do Reino de Portugal e de Espanha tinha não só uma dimensão político-administrativa, mas também religiosa. Com a criação do Padroado, muitas das atividades características da Igreja Católica eram, na verdade, funções do poder político"
} 
indicação de valores morais que deveriam ser passados na educação básica. Vê-se uma ainda hegemonia da Igreja Católica como instituição garantidora da moral.

Com a força dos movimentos republicanos, na segunda metade do século XIX esse cenário começa a se alterar. Outras doutrinas cristãs e outras visões de mundo passam a ganhar força no cenário político brasileiro. Um exemplo desse cenário de disputas é a proposta que Ruy Barbosa apresenta na câmara dos deputados em 1882, em seu art. 1', § $3^{\circ}$ diz (BARBOSA, 1942, grifos nossos):

"Nas es"colas primárias do Estado, bem como em todas as que forem sustentadas ou subvencionadas à custa do orçamento do Império, ou de quaisquer propriedades, impostos, ou recursos, seja de que ordem forem, consignado, neste, ou noutra qualquer lei geral, ao serviço de instrução pública, é absolutamente defeso ensinar; praticar; autorizar ou consentir o que quer que seja, que importe profissão de uma crença religiosa ou ofenda a outras.

I. O ensino religioso será dado pelos ministros de cada culto, no edifício escolar; se assim o requererem aos alunos cujos pais o desejam, declarando-o ao professor, em horas que regularmente se determinarão sempre posteriores às da aula, mas nunca durante mais de quarenta e cinco minutos cada dia, nem mais de três vezes por semana.

II. A escola subvencionada nos termos do § perderá, se o infringir, a subvenção, por simples ato do inspetor geral da instrução primária, com recurso para o governo.

III. Os professores das escolas do Estado e das que forem manadas exclusivamente pelos meios a que se refere este parágrafo, transgredindo-o, sofrerão a pena de suspensão por seis meses a um ano. A suspensão é pronunciada pelo inspetor geral, com recurso para o governo.

IV. O pessoal das escolas a que se refere este parágrafo, a princípio, é exclusivamente leigo. A admissão de um professor; a quem falte este caráter, numa escola subvencionada, sujeita a pena deste parágrafo $\mathrm{n}^{\circ} \mathrm{II}$.

V. A qualidade de funcionário na administração, direção, ou inspeção do ensino público, primário, secundário ou superior; é incompatível com o caráter eclesiástico, no clero secular; ou regular; de qualquer culto, igreja ou seita religiosa."

Nesse projeto de lei, que não foi aprovado pela câmara, podemos ver o enfrentamento de ideias que ocorre nesse momento histórico. Podemos ver o republicano Ruy Barbosa propor ideias diferentes da então hegemonia católica no ensino. Reconhecendo a existência de outras religiões na sociedade brasileira, o intelectual propõe a proibição de profissão religiosa nas escolas, assim como a educação religiosa como responsabilidade do ministro de cada culto, o que retira o caráter de um culto hegemônico no Estado brasileiro.

Temos assim, uma prévia das ideias que vão emergir com mais força na virada do sistema político monarquico para o republicano. 


\subsection{3. Ensino e religião na Primeira República}

Com a proclamação da República em 1889, tendências políticas diferentes se manifestaram com mais clareza. Nesse momento, a laicidade se tornou uma meta governamental, um elemento importante a ser atingido pelas ideias republicanas, natadamente na construção de uma diferença com relação à monarquia, por isso, desde o governo provisório republicano podemos ver esforços nesse sentido. No entanto, esse continua sendo um território de disputa, com a igreja católica buscando participar ativamente do processo, em uma tentativa de não perder sua área de influência.

"Era expectativa da Igreja Católica que as leis gerais da separação e da secularização fossem feitas por meio de um entendimento cordial com a Santa Sé...Assim, no dia 21.11.1889, o Primaz do Brasil, Arcebispo da Bahia, D. Luiz Antônio dos Santos, envia telegrama ao Marechal Deodoro implorando as bênçãos do céu sobre os esforços dos filhos da Terra de Santa Cruz, pela sua prosperidade e felicidade. Com efeito, no final de 1889, o decreto já ia ganhando forma,. quer pela lavra de Rui Barbosa, quer pelas aspirações dos positivistas, através do Ministro da Agricultura, Demétrio Ribeiro" (CURY, 1993).

Apesar da ação da Igreja, há a jurídica separação entre Igreja e Estado com o fim do Padroado. O decreto de separação entre tais esferas ocorre em 1890, no entanto, dava margem de negociação no seu atigo $6^{\circ}$ :

"Art. $6^{\circ} \mathrm{O}$ Governo Federal continúa a prover á congrua, sustentação dos actuaes serventuarios do culto catholico e subvencionará por anno as cadeiras dos seminarios; ficando livre a cada Estado o arbitrio de manter os futuros ministros desse ou de outro culto, sem contravenção do disposto nos artigos antecedentes".

Percebe-se, portanto, uma tentativa de composição, mas há uma efetiva reação da igreja católica contra o principio da laicidade. A Pastoral Coletiva dos Bispos Brasileiros de 19.03.1890 não só aponta essa separação como ofensiva à "ordem das coisas", como lamenta o decreto pelo fato de que o Estado quer se separar daquela instituição. (CURY, 1993)

A constituição de 1891, em relação especificamente ao ensino diz, através do $\S$ $6^{\circ}$ do art. 72 diz que "Será leigo o ensino ministrado nos estabelecimentos públicos. (BRASIL, 1891).

Segundo Cury, a reação da igreja, no entanto, se dará no âmbito estadual e não no federal: Ceará, Minas Gerais, Rio Grande do Sul, Sergipe, Pernambuco e Santa Catarina reintroduzem o ensino religioso facultativo nas escolas públicas. 
Isso mostra a flexibilização, a negociação possível citada anteriormente. Dá-se, pois, uma interação conflituosa entre o dispositivo da laicidade e sua aplicação nos Estados, habilmente trabalhada pela igreja.

Livre da centralização do Estado, e agora autônoma, a igreja se fortalece no âmbito regional e a instituição acaba tendo uma forte mobilização não só pela via das congregações religiosas no campo educacional escolar, como também através da imprensa: estabelece uma luta num campo de formação da opinião pública, disputando com outras vertentes jornalísticas. (CURY, 1993).

Apesar das reações da igreja e de parlamentares católicos, o Brasil sai da chamada "Primeira República", tendo juridicamente um ensino leigo, não religioso, ministrado em suas escolas públicas.

\subsection{4. \\ Ensino religioso nos anos 30}

Os anos 30 representaram uma retomada do ensino religioso nas escolas públicas. As mobilizações católicas anteriores resultaram na Revolução, significando um fortalecimento da igreja católica ao cenário político brasileiro, que soube aproveitar a existência de um governo provisório para pleitear sua volta à educação oficial.

"O possível apoio da Igreja foi entendido por Vargas. Ser-lhe-ia preciosa vantagem, bem como às forças representadas por ele. Em troca do apoio, o quase reconhecimento oficial da Igreja pela Estado. E foi o que aconteceu. Mas para que a 'barganha' se completasse, um longo caminho teria que ser percorrido" (CURY, 1993)

O caminho encontrado para a manutenção da influência num regime sem o Padroado foi da exigência de um ensino religioso nas escolas e em abril de 1931, a comissão montada pela igreja para fazer a pressão por essa plataforma é acolhida no decreto $\mathrm{n}^{\circ} 19.941$ de 30.04.1931: decreta:

"O Chefe do Governo Provisório da República dos Estados Unidos do Brasil

Art. $1^{\circ}$ - Fica facultativo, nos estabelecimentos de instrução primária, secundária e normal, o ensino da religião.

Art. $2^{\circ}$ - Da assistência às aulas de ensino religioso haverá dispensa para os alunos, cujos pais ou tutores, no ato da matrícula, a requererem.

Art. $3^{\circ}$ - Para que o ensino religioso seja ministrado nos estabelecimentos oficiais de ensino é necessário que um grupo de, pelo menos, vinte alunos se proponha a recebê-lo. Art. $4^{\circ}$ - A organização dos programas de ensino religioso e a escolha dos livros de texto ficam a cargo dos ministros do 
respectivo culto, cujas comunicações, a este respeito, serão transmitidas às autoridades escolares interessadas.

Art. 5' - A inspeção e vigilância do ensino religioso pertencem ao Estado, no que respeita à disciplina escolar, e às autoridades religiosas, no que se refere à doutrina e à moral dos professores.

Art. $6^{\circ}$ - Os professoras de instrução religiosa serão designados pelas autoridades do culto a que se referir o ensino ministrado. " (BRASIl, 1931)

É possível notar nesses artigos que, apesar de ser uma conquista da igreja católica, a presença do ensino religioso ganha novos contornos com o crescimento de outras religiões ou, no mínimo, sua não criminalização ou ocultamento, o que leva à admissibilidade da variedade de cultos no ensino religioso no artigo $6^{\circ}$, por exemplo.

Assim, em meio às propostas da Escola Nova ${ }^{8}$, que defendia o ensino laico, público, gratuito e de qualidade, o governo acaba por incluir o ensino religioso no currículo das escolas públicas de ensino fundamental, que continua presente nas constituições de 1934 e 1937, de forma facultativa, mas presente. Na verdade, a partir da constituição de 1934, o ensino religioso aparece em todas as constituições federais e na Lei de Diretrizes e Bases da Educação Nacional(MUNIZ, 2012). Há, nesse processo, discussões e variações no seu caráter facultativo e confessional, mas penso que para o presente trabalho, não seja necessário entrar em detalhes sobre cada uma das variações, valendo-me apenas de sua indicação.

\subsection{5.}

\section{A discussão nos dias atuais}

A despeito de alterações nas práticas sociais, que abarcam desde o significado da religião ou da prática religiosa nos diferentes momentos do século XX republicano até os registros de diversidade cultural e direitos humanos, é importante ressaltar que a Constituição em vigor, oriunda de um novo pacto entre sociedade e estado após uma ditadura militar, assegura o ensino religioso nas escolas, na condição de oferta obrigatória no currículo do ensino fundamental, conforme prescreveram a Constituição Federal (1988) e a LDB (1996/97), (MUNIZ, 2014).

\footnotetext{
${ }^{8} \mathrm{O}$ movimento educacional brasileiro nomeado Escola Nova ganhou força nos anos 30 após a divulgação do Manifesto dos Pioneiros da Educação Nova (1932). Nesse documento, defendia-se a universalização da escola pública, laica e gratuita. Ver NUNES (2008)
} 
No caso, vale ainda mencionar que, mesmo após o fim do vínculo oficial entre Igreja e Estado, as Constituições brasileiras tiveram como marca um preâmbulo com referência à Deus, exibindo, portanto uma intenso vínculo que acredito que se expresse no espaço escolar.

Como mais recente discussão dessa controvérsia sobre o ensino religioso, tivemos a discussão no plenário do STF sobre a permissão, ou não da confessionalidade $^{9}$ do ensino religioso. A Lei de Diretrizes e Bases, em seu artigos 33, diz que:

“Art. 33. O ensino religioso, de matrícula facultativa, é parte integrante da formação básica do cidadão e constitui disciplina dos horários normais das escolas públicas de ensino fundamental, assegurado o respeito à diversidade cultural religiosa do Brasil, vedadas quaisquer formas de proselitismo. (Redação dada pela Lei $\mathrm{n}^{\circ}$ 9.475, de 22.7.1997)

$\S 1^{\circ}$ Os sistemas de ensino regulamentarão os procedimentos para a definição dos conteúdos do ensino religioso e estabelecerão as normas para a habilitação e admissão dos professores. (Incluído pela Lei $n^{\circ} 9.475$, de 22.7.1997)

$\S \mathbf{2}^{\mathbf{0}}$ Os sistemas de ensino ouvirão entidade civil, constituída pelas diferentes denominações religiosas, para a definição dos conteúdos do ensino religioso. (Incluído pela Lei no 9.475 , de 22.7.1997)"

Como pode ser observado, a lei é bem vaga no que diz respeito à forma como o ensino religioso pode ser ministrada. Alguns sistemas de ensino, como do Estado do Rio de Janeiro, já aplicam o ensino religioso de forma confessional desde o ano de 2000.

Tendo-se isso em vista, em setembro de 2017, o Superior Tribunal Federal julgou uma Ação Direta de Inconstitucionalidade, que havia sido proposta pela Procuradoria Geral da República (PGR). A ação pedia a interpretação conforme a Constituição Federal ao dispositivo da Lei de Diretrizes e Bases da Educação LDB (caput e parágrafos $1^{\circ}$ e $2^{\circ}$, do artigo 33, da Lei 9.394/1996) para assentar que o ensino religioso nas escolas públicas não pode ser vinculado a religião específica e que fosse proibida a admissão de professores na qualidade de representantes das confissões religiosas. Sustentava que tal disciplina, cuja matrícula é facultativa, deve ser voltada para a história e a doutrina das várias religiões, ensinadas sob uma perspectiva laica.

No entanto, a maioria dos ministros do Supremo considerou que há como pregar a religiosidade e crenças específicas em escolas públicas sem violar a laicidade do Estado. "Não consigo vislumbrar nas normas autorização para o

\footnotetext{
${ }^{9}$ Confessionalidade é a possibilidade de o ensino religioso ser ministrado por uma religião específica.
} 
proselitismo ou catequismo. Não vejo nos preceitos proibição que se possa oferecer ensino religioso com conteúdo especifico sendo facultativo", defendeu a ministra Cármen Lúcia, que desempatou a votação.

Essa breve explanação nos informa que a religião esteve oficialmente na escola por todo o período da história do Brasil - a não ser pelo breve período da Primeira República - assim, mais do que expressão de uma cultura que alunos e professores carregam consigo, por muito tempo foi valor reforçado pela existência do ensino religioso nas escolas, o que sem dúvida é uma tradição com a qual o momento presente deve dialogar.

\section{5.}

\section{Para além do ensino religioso}

Apesar de o ensino religioso ser uma controvérsia explícita acerca da relação entre escola e religião, não é apenas dessa forma que a religião se coloca na escola. A religião está presente na escola. Independente da presença, ou não, da disciplina de ensino religioso, as relações que ocorrem no espaço escolar são frequentemente permeadas. Ao entrarem no ambiente escolar, tanto professores como alunos, assim como todo o corpo de funcionário, carregam valores, dentre eles os valores religiosos. Estudos como o de Quintana (2013), e Valente (2015, 2017) atestam a presença não apenas do aspecto religioso no espaço escolar, mas também de situações de intolerância.

A pesquisa de Quintana (2013) teve como objetivo discutir o significado da escola para famílias candomblecistas. $O$ autor utilizou a metodologia de entrevistas semiestruturadas para entrevistar três professoras candomblecistas da rede pública de ensino do Rio de Janeiro, municipal e estadual. Nas entrevistas com as professoras, a intolerância religiosa ganha centralidade, em especial, ao enfocar a relação escola-religiões afro-brasileiras.

Apesar de uma das entrevistadas evidenciar e destacar a maneira como é ministrado o ensino religioso como o problema central na relação entre religião e escola, o autor chega à conclusão de que as professoras, ao serem identificadas como praticantes do Candomblé, são discriminadas pelos seus próprios colegas e alunos, independentemente da existência do ensino religioso. 
O texto de Valente (2015) apresenta resultados de uma pesquisa sobre a presença da religiosidade na escola pública. Em um estudo de inspiração etnográfica, a autora acompanhou duas turmas de ensino fundamental I em um município de São Paulo; Como conclusão principal do estudo, Valente afirma que, diferentemente do que se imaginava, a religião não está presente na escola de maneira explícita, mas de forma oculta e difusa, como uma forte influência na prática docente das professoras. Para a autora, tal realidade acaba ferindo o princípio de laicidade do Estado.

A autora mostra que a religiosidade está, principalmente, em atos e falas das próprias professoras observadas, mesmo que não haja aulas de ensino religioso ou símbolos religiosos na decoração dos espaços escolares estudados (VALENTE, 2015). Assim, é possível afirmar que a religiosidade está presente no espaço escolar, sendo trazida para dentro dos muros da escola por meio de seus agentes que carregam a dimensão da religiosidade em sua identidade. Em outras palavras, os professores seriam agentes sociais que acentuam a interdependência entre as agências por circularem tanto na instituição religiosa quanto na escola.

$\mathrm{Na}$ escola, portanto, a religião está presente independente da presença, ou não, de uma disciplina de ensino religioso. Como um lugar de encontro entre pessoas, a escola expõe os valores e crenças dessas pessoas: as relações que ocorrem no espaço escolar são o tempo todo permeadas por questões pessoais que, como tais, envolvem crenças e não crenças religiosas de professores, alunos, gestores, família, funcionários e demais membros da comunidade escolar.

\section{6.}

\section{A intolerância religiosa}

Primeiramente, antes de abordar a intolerância religiosa, é preciso realizar uma reflexão sobre o polissêmico conceito de tolerância. A polissemia desse conceito se dá em dois aspectos distintos. $\mathrm{O}$ primeiro desses aspectos se refere às ideias de identidade e diversidade. O conceito de tolerância pode, como nos mostra Cardoso (2003), se balizar em uma dessas duas ideias, o que muda o modo como pode ser visto. Com isso quero dizer que em um primeiro momento a tolerância se limita à identidade do homem europeu, e só depois abarca a ideia de diferentes realidades, da diversidade. O segundo aspecto da polissemia do 
conceito se refere a encarar (ou não) como válido para pensar as relações humanas. Segundo Andrade (2009) e Menezes (1996), há na sociedade a ideia de que a palavra "tolerância" é sinônimo de indiferença, como atitude de superioridade, onde se tolera o outro por pura complacência. Segundo Menezes (1996, p.6) "Muita gente rejeita, de entrada, o termo; pois lhe lembra as "casas de tolerância", e uma atitude neutra de quem não quer aceitar e muito menos amar o outro, mas apenas 'tolerar', permitir como um favor ou condescendência, que ele exista. Outros acham que a tolerância supõe abdicar da verdade, da certeza, e submergir num total relativismo, desacreditando todos os valores. Outros dizem que é, no fundo, um conceito contraditório, pois os tolerantes sempre supõem um limite, sempre admitem algo "intolerável" (pelo menos a própria "intolerância")".

Segundo Menezes (1996), a atitude tolerante só nasce em resposta à intolerância existente, o que reforça a ideia da tolerância ser uma ação positiva, uma escolha. Isto é, não é uma atitude de indiferença, mas sim de abertura para o diferente, de admissão de existências de diversas faces de uma mesma verdade. A violência do mundo está associada ao conceito, pois o a violência como resposta ao que não é o próprio é a intolerância: em um mundo violento, a tolerância se faz necessária. É antes uma reação contra uma situação dada: contra a intolerância nascida do etnocentrismo, da rejeição do outro. A tolerância é uma negação da negação, suscitada pela indignação frente à intolerância; é a defesa de um direito humano dos mais sagrados: o direito à diferença. Equivale a declarar que o intolerável mesmo é a intolerância.

\subsection{1.}

\section{As origens do conceito}

O momento em que se inicia a reflexão filosófica mais conhecida sobre essa temática é no século XVI, pois a Renascença tem um papel primordial nessa discussão. Segundo Costa (1999, p.31): "Com o desenvolvimento do Renascimento, a tolerância adquire uma importância fundamental. A par de um sentimento generalizado contra a Igreja, promove-se também um sentimento de maior tolerância relativamente a todos aqueles que professam doutrinas religiosas diferentes". Nesse contexto, a Reforma Protestante abalava a cristandade europeia e já se viam inúmeros conflitos religiosos. Não que não existissem conflitos religiosos antes, já que os 
turcos ou mouros enfrentavam a cristandade desde o século $\mathrm{V}$. Contudo, um racha intenso dentro da concepção cristã europeia mudou a natureza de tais conflito. Em resposta direta a situações de intolerância religiosa, autores como Erasmo de Roterdã e Thomas More ajudaram a fundar o conceito na medida em que criticavam as práticas violentas da Igreja Católica para com outras práticas religiosas. Em More, por exemplo, podemos ver na sua clássica obra "Utopia" uma sociedade em que a religião dos habitantes da Ilha á baseada na crença de um Deus “único, eterno, imenso, desconhecido, inexplicável”, mas que cada um tem a liberdade de adorar como queira. Na ilha imaginada por More, o Estado não poderia obrigar que os moradores fossem de nenhuma religião específica, já que a prática religiosa na ilha seria um ato individual, realizado na própria consciência e esta não poderia ser violada. Já podemos ver nesse exemplo de um pensador do século XVI a ideia de que o Estado não pode interferir nas práticas religiosas da população, posto que essa prática é fruto de uma consciência. Apesar do autor não falar em "tolerância" explicitamente, vemos no século XVI o início de um pensamento que se acentuaria com John Locke no século XVII, a ideia de que a religião é uma prática da sociedade civil, onde deve haver liberdade. More e outros autores, portanto, nos ajudam a ver o nascimento de ideias de tolerância em contexto religioso conturbado, mas é nos séculos XVII e XVIII em que, através do inglês John Locke e do francês Voltaire, o conceito é diretamente referenciado e aprofundado. John Locke (1632-1704) viveu na Inglaterra em um contexto de intensas disputas entre protestantes e católicos. O filósofo reage a essa situação com sua obra Cartas Acerca da Tolerância (1973).

Nessa obra, Locke aborda as liberdades individuais como elemento essencial do sistema político. Ganham destaque na sua explanação a defesa da liberdade de expressão, o culto como um direito básico do indivíduo e a defesa da separação entre comunidade civil e comunidade religiosa. Segundo Andrade (2009,p 47):

"Escrita para um público douto, a Carta se baseia em posicionamentos filosóficos até então pouco consolidados e recorre, com frequência, à exegese de textos do Novo Testamento e à interpretação de liturgias cristãs e pagãs como argumentos para a tolerância, o que faz do texto não só um registro de reflexões filosóficas, mas também teológicas, litúrgicas e antropológicas".

É interessante notar, portanto, que Locke não propõe uma saída da religião católica, até porque se vê que muitos dos seus argumentos se baseiam na própria 
concepção cristã de mundo. O que se propõe, a partir dessa concepção cristã, é o respeito às diferentes formas de se acreditar em Deus, inclusive o ateísmo não entra no rol de práticas a serem toleradas. Locke (1973, p.9) diz:

"Se se acredita no Evangelho e nos apóstolos, ninguém pode ser cristão sem caridade, e sem a fé que age, não pela força, mas pelo amor. Assim sendo, apelo à consciência dos que perseguem, atormentam, destroem e matam outros homens em nome da religião, se o fazem por amizade e bondade(...) Desde que pergunta minha opinião acerca da mútua tolerância entre os cristãos, respondo-lhe, com brevidade, que a considero o sinal principal e distintivo de uma verdadeira Igreja".

Nota-se, com essa passagem, que o principal dever da igreja cristã para Locke era justamente a tolerância, o amor aos outros. Vê-se aí um argumento cristão sobre a tolerância e não uma recusa à Igreja. Mas, a principal contribuição do autor em sua Carta é a separação que faz entre a sociedade civil e a igreja. Para Locke, a comunidade é uma sociedade de homens constituída apenas para a preservação e melhoria dos bens civis de seus membros.

Por bens civis Locke entendia a vida, a liberdade, a saúde física e a posse de coisas externas (terras, dinheiro, móveis, etc.). A comunidade, segundo ele, deveria ser dirigida por um magistrado civil através, principalmente, do poder da legislação e da coerção. Por sua vez, a igreja seria uma sociedade livre, de homens reunidos entre si por iniciativa própria para o culto público de Deus, em suma, uma sociedade livre e voluntária. A igreja cuidaria, com suas autoridades eclesiásticas, do culto a Deus e do encaminhamento das almas que livre e voluntariamente optassem em seguir a sua doutrina.

Dessa forma, o autor separa a situação da igreja da sociedade civil. O que Locke defendeu na sua carta, portanto, foi o caráter íntimo e pessoal da religião. O autor entendia que as convicções não deveriam ser impostas. "Porque cada igreja é ortodoxa para consigo mesma e errônea e herege para as outras". A tolerância, para Locke, significa a garantia da possibilidade da diversidade. Argumenta a favor da diversidade como um dado de realidade, como algo inquestionável e, por isso mesmo, plenamente possível de ser aceita, como afirma:

"Não é a diversidade de opiniões (o que não pode ser evitado), mas a recusa de tolerância para os que têm opinião diversa, o que se poderia admitir, que deu origem à maioria das disputas e guerras que se têm manifestado no mundo cristão por causa da religião" (LOCKE, 1973, p.33).

Já Voltaire escreve sobre o mesmo tema no século XVIII: Tratado sobre a tolerância: a propósito da morte de Jean Calas (1763/2011). O contexto francês 
na época era de extrema exclusão dos protestantes, pois havia sido revogado há pouco tempo o Edito de Nantes, que dava liberdade de culto aos protestantes. No momento em que Voltaire escreve o tratado, os direitos civis dos não católicos não existem, contrariando a ideia de separação entre igreja e sociedade civil sugerida por More no século XV e explicitada por Locke no XVII.

Voltaire escreveu o Tratado motivado pelo que acreditava ser uma injustiça jurídica levada a cabo pela intolerância religiosa, o processo de Jean Calas. Jean Calas pertencia a uma família protestante huguenote, com exceção do seu filho, convertido. Depois do suicídio do seu filho, Calas foi acusado de homicídio voluntário. A família é presa e o pai, a pedido da população e segundo ordem de oito juízes, é condenado à pena de morte mesmo na ausência de provas. Jean Calas foi morto, confessando inocência. Voltaire acreditava que Calas só havia sido condenado por ser protestante, visto que o personagem já tinha um outro filho convertido ao catolicismo e não o matou por isso. Esse drama foi, portanto, o motivo da escrita do tratado por Voltaire (2011, p.8):

\begin{abstract}
"Algum fanático da populaça gritou que Jean Calas havia enforcado seu próprio filho Marc-Antoine. Esse grito, repetido, logo tornou-se unânime; outros acrescentaram que o morto pretendia fazer abjuração no dia seguinte; que sua família e o jovem Lavaisse o haviam estrangulado por ódio contra a religião católica. Um momento depois, ninguém duvidava mais; toda a cidade foi persuadida de que é um imperativo religioso entre os protestantes que um pai e uma mãe devem assassinar seu filho tão logo ele queira converter-se"
\end{abstract}

Voltaire faz, durante todo o Tratado, uma crítica contundente à igreja católica. Assim como Locke, argumenta que a igreja perdeu seu verdadeiro propósito cristão, pois não seguiu os ensinamentos do seu Messias. Considera-a perseguidora, enquanto quase todo o restante das palavras e das ações de Jesus Cristo prega a doçura, a paciência e a indulgência. A ideia de tolerância exposta no Tratado é a de que ela só seria alcançada se a religião fosse superada pelos argumentos racionais. Essa proposição mostra o contexto iluminista em que o autor escreve, onde a fé vai sendo substituída pela razão no que diz respeito à explicação do mundo:

"O melhor método de diminuir o número dos maníacos, se é que existe, é o de deixar essa doença do espírito sob o controle da razão, que esclarece aos homens lentamente, mas de maneira infalível. A razão é doce, é humana, inspira a indulgência, abafa a discórdia, fortalece a virtude, torna agradável a obediência às leis, mais ainda que a força pode obrigar a cumpri-las" (VOLTAIRE, 2011, p.25) 
Por fim, é importante notar que a argumentação para a estupidez da intolerância em Voltaire é baseada na ideia de igualdade entre os homens, uma igualdade baseada em Deus:

"Não é preciso ter grande arte nem dispor de eloquência bem-elaborada para provar que os cristãos devem tolerar uns aos outros. Mas eu vou mais longe: eu lhes digo que é necessário considerar todos os homens como nossos irmãos. O quê? Meu irmão, o turco? Meu irmão, o chinês? O judeu? O siamês? Sim, sem a menor dúvida, pois não somos todos filhos do mesmo pai, criaturas do mesmo Deus?" (VOLTAIRE, 2011, p.88)

Discutida a ideia de tolerância e suas características para os dois autores da era moderna, vemos que ambos se baseiam na ideia de identidade. Como nos informa Cardoso (2003) para Locke e Voltaire a tolerância à diversidade de posições religiosas não chegou a ultrapassar rigorosamente os limites da identidade do próprio cristianismo como a única religião verdadeira.

$\mathrm{Na}$ esfera política, o termo tolerância no ideário burguês da modernidade também revela uma forte influência do princípio de identidade. Os chamados valores universais iluministas, constituintes Declaração dos Direitos do Homem e do Cidadão, não levam em conta a diversidade étnica, racial e cultural de toda humanidade. A pluralidade humana tinha como modelo a identidade do homem europeu.

Isso nos mostra que, apesar de avançarem na discussão do conceito, há uma clara limitação na concepção desses autores: só é tolerável como igual aquele que se enquadra na identidade do homem europeu, do que é reconhecido naquele momento.

Com riscos de sermos anacrônicos, não podemos 'cobrar' de tais autores uma concepção mais ampla, entretanto, justamente localizar seus limites é importante para reconhecermos como é construído o conceito hoje, identificando sua historicidade.

Fala-se de um homem como se fosse o homem. A pluralidade humana tinha como modelo a identidade do homem europeu. Proclamam-se direitos iguais entre semelhantes, os europeus, uma identidade única em que suas variações deveriam ser toleradas, não se aplicando a outros povos, tidos como inferiores, por exemplo. 


\subsection{2.}

\section{Impressões contemporâneas da tolerância}

É a experiência do século XX e o descentramento da produção de conhecimento que vai alterar os parâmetros da tolerância como referida hoje. A verdade da identidade foi questionada haja vista a reflexão de Stuart Hall (2004) e a alteridade valorizada (como mencionado antes, na afirmação positiva da diversidade no Pós Segunda Guerra).

Com pensamentos de autores de lugares "não europeus", como a América Latina (CARDOSO, 2003), a tolerância se transforma num conceito que incorpora a noção de alteridade, num equilíbrio entre identidade/alteridade. Nesse sentido, o conceito mais contemporâneo se refere ao reconhecimento da diversidade cultural a partir da valorização da identidade de sua própria cultura. O que isso significa? Significa que o respeito de um povo às culturas diferentes depende fundamentalmente da consciência clara da identidade e do valor de sua própria cultura. A identidade cultural, por sua vez não é algo estático, acabado. Está sempre se transformando com a dissolução de aspectos culturais do passado e com a assimilação de novas culturas no contato com outros povos.

Antes, em um contexto iluminista, universalista, a tolerância passava pela ideia de igualdade entre os homens, agora se pensa na tolerância relacionada à diversidade. Os homens não precisam ser iguais para serem igualmente respeitados. A mudança do paradigma da tolerância passa pela fundação da Organização das Nações Unidas (ONU) e confunde-se com seu próprio desenvolvimento. A organização tem sua origem no pós-Segunda Guerra Mundial, evento onde a intolerância ao diferente matou mais de 50 milhões de pessoas (HOBSBAWN, 1955). Em seu documento de fundação, a Carta das Nações Unidas, estabelece-se que um dos objetivos da organização é "praticar a tolerância" e ajudar as nações a "conviver como bons vizinhos (UNESCO, 1955).

Tolerância aparece, então, desde o princípio como um dos fundamentos para a convivência pacífica entre as nações. Vemos, a partir dessa definição, a diferença com o paradigma que analisamos nos autores iluministas. Para aqueles há uma limitação da tolerância como respeito para os que compartilham sua identidade, do mundo europeu. 
Já para a concepção mais contemporânea, analisada por Cardoso (2003) e definida pela ONU, há uma igualdade entre diferentes nações que devem se respeitar como iguais, porém levando em conta suas particularidades, a tolerância, portanto, está conexa justamente ao reconhecimento e ao respeito das diferenças.

Para analisar a noção da ONU do conceito, veremos então a Declaração de Princípios sobre a Tolerância da UNESCO (1995). Em seu primeiro artigo, o conceito de tolerância é definido como:

“[...] o respeito, a aceitação e o apreço da riqueza e da diversidade [...] não é concessão [...] é uma atitude ativa fundada no reconhecimento dos direitos universais da pessoa humana e das liberdades fundamentais do outro [...]. Praticar a tolerância não significa [...] renunciar as próprias convicções, nem fazer concessões a respeito. A prática da tolerância significa que toda pessoa tem a livre escolha de suas convicções e aceita que o outro desfrute da mesma liberdade. Significa que ninguém deve impor suas opiniões a outrem".

Vemos nessa perspectiva que a prática da tolerância, para a UNESCO, é um fator básico para a convivência entre diferentes povos. Essa concepção apresentada está de acordo com a perspectiva conceitual que aqui adotamos. Como defendem Andrade (2009) e Menezes (1996), a tolerância não é uma atitude de indiferença ou ceticismo, mas um respeito ativo às escolhas do outro. É, sem se abster de suas convicções, entender que outras convicções são válidas. Defendemos que a educação pode atuar como um importante fator de promoção da tolerância. Propor uma educação para a tolerância responde a um projeto de mundo plural, implicando na prevenção e combate em relação às práticas de intolerância.

Nesse espírito, a declaração da UNESCO também atribuiu à educação um espaço privilegiado para a difusão dos valores da tolerância, no seu artigo $4^{\circ}$.

“A educação é o meio mais eficaz de prevenir a intolerância. [...] uma educação para a tolerância, consiste em ensinar aos indivíduos quais são seus direitos e suas liberdades a fim de assegurar seu respeito e de incentivar a vontade de proteger os direitos e liberdades dos outros. [...] políticas e programas de educação devem contribuir para o desenvolvimento [...] da compreensão, da solidariedade e da tolerância entre os indivíduos, entre os grupos [...] culturais, religiosos [...] e as nações. A educação para a tolerância [...] deve ajudar os jovens a desenvolver sua capacidade de exercer um juízo autônomo, de realizar uma reflexão crítica e de raciocinar em termos éticos. Torna-se necessário dar atenção [...] aos conteúdos [...] a fim de formar cidadãos solidários e responsáveis, abertos a outras culturas, capazes de apreciar o valor da liberdade, respeitadores da dignidade dos seres humanos e de suas diferenças e capazes de prevenir os conflitos ou de resolvê-los por meios não violentos.” 
Em nosso trabalho, parto da perspectiva de que a tolerância é uma atitude ativa de respeito ao outro, não uma atitude de passividade ou de total relativismo. Acreditamos que seja uma ação e escolha no modo de lidar com o mundo e o que é diverso, rejeitando a submissão da diversidade a nossos parâmetros. Acredita-se que o conceito de tolerância tenha sido desenvolvido a partir da discussão na Renascença em resposta à intolerância religiosa expressada em conflitos entre Católicos e Protestantes. No mundo plural em que vivemos, diversas formas de intolerância são vistas nas mais diversas situações.

Assim, como a ONU, também eu acredito no papel da escola como promotora da tolerância. No entanto, a educação escolar não se resume à sala de aula, por isso vamos abordar aqui o conceito de "cultura escolar".

\section{7. Cultura escolar}

A nossa pesquisa se situa no espaço escolar. Entender a função e os mecanismos próprios desse local só é possível através da reflexão sobre o espaço e as características dessa dinâmica.

O conceito de cultura escolar é um importante elemento constitutivo da nossa questão. A escola é um local de formação essencial para a nossa sociedade. Nela podemos perceber tanto o movimento de conservação de valores que devem ser passados para as gerações mais novas quanto o de alteração de práticas e costumes através da geração mais jovem que ali está.

A cultura escolar é um conceito que podemos definir como o conjunto de visões e valores que uma instituição escolar apresenta (TURA, 2011). Segundo a autora, a cultura escolar pode ser observada na organização de seu espaço físico, no estilo dos móveis, nas diferentes disposições do ambiente e na forma de sua edificação; assim como pode ser constatada nos padrões de relacionamento social, nas expectativas de comportamento e nas regras e normas de sua organização. Dessa forma, é uma reflexão importante para essa pesquisa, na medida em que o pensamento sobre a presença da religião na escola passa diretamente por suas regras e seus costumes internos, constituintes da cultura escolar. A cultura escolar, desse modo, é um círculo que abrange diversos fatores. Ou seja, tudo que acontece na escola faz parte de uma cultura própria que decorre, segundo Perez 
Gomes (1994) de um cruzamento de culturas. Dentre um dos elementos que atravessam e constituem a cultura escolar, podemos considerar a presença da religião na escola.

Seguindo a leitura do texto de Vera Candau (2002), identificamos três principais autores que trabalham esse o conceito de cultura escolar: Gimeno Sacristán, Angel Pérez Gomez e Jean Claude Forquin.

Girmeno Sacristán (1997), catedrático de didática e organização escolar da Universidade de Valência (Espanha), com uma ampla produção com temas relacionados ao ensino, currículo, formação de professores e reformas educativas, parte da afirmação da intima relação entre cultura escolar e currículo, colocando o eixo da discussão na própria ideia de currículo. O autor distingue dois currículos. O primeiro é o currículo da visão formal, que é aquele relacionado ao conteúdo, uma mera especificação de um documento, de todos os objetivos, áreas, que devem ser tratados em aula. O segundo é nomeado de currículo real, que inclui todas as aprendizagens do aluno no contexto escolar, e é a esse que o autor relaciona a cultura escolar. Sua concepção de cultura escolar é como um jogo de intercâmbios e interações presentes na dinâmica escolar, em que estão presentes crenças, aptidões, valores, atitudes e comportamentos dos sujeitos implicados no processo. O autor concebe a cultura escolar como um produto singular, com significado próprio.

Perez Gomez (1994), catedrático de didática e organização escolar da universidade de Málaga, também com uma ampla produção em temas relacionados ao ensino, currículo, formação de professores e reformas educativas, concebe a escola como um espaço de cruzamento de culturas, que tem o papel de mediar as influências plurais. $\mathrm{O}$ autor define a cultura escolar como os papeis, normas, rotinas e ritos próprios da escola como instituição social específica.

Jean Claude Forquin (1993) apresenta a cultura escolar como sendo aquele conjunto de saberes que, uma vez organizado, didatizado, compõe a base de conhecimentos sobre a qual trabalham professores e alunos. Nessa ideia está pressuposta uma seleção prévia de elementos da cultura humana, científica ou popular, erudita ou de massa. $\mathrm{O}$ autor contrapõe o conceito de cultura escolar ao de cultura da escola. A escola seria uma instituição ímpar, que se estrutura sobre processos, normas, valores, significados, rituais, formas de pensamento, constituidores da própria cultura, que não é monolítica, nem estática, nem 
repetível. É esse conjunto de características do cotidiano escolar que Forquin denomina de cultura da escola.

Portanto, o que os primeiros dois autores chamam de cultura escolar, como sendo mais do que aquilo formalmente estabelecido, mas as relações que se dão na escola, Forquin chama de cultura da escola.

Os três autores, no entanto, me parecem considerar a escola como um espaço plural, de múltiplos grupos e que as relações que ocorrem dentro do seu espaço constituem uma cultura específica. Esse aspecto é importante para desenvolver a pesquisa proposta nesse projeto, pois considerar a escola como um espaço plural permite pensarmos como essa pluralidade é encarada no espaço escolar.

Como uma instituição social, a escola possui suas próprias práticas e formas de organização. Entendo aqui a cultura escolar como aquele conjunto de práticas, normas, ideias e procedimentos que se expressam em modos de fazer e pensar o cotidiano da escola, mas, além disso, compreendo a escola e suas práticas como um local de conflito, um local onde diferentes perspectivas se encontram, sendo constituinte de sua "cultura". É na cultura escolar, nesse espaço de símbolos, comportamentos e perspectivas, que investigo.

Seguindo o trabalho de Valente (2015), a religião está impregnada na cultura escolar, de maneira muitas vezes intolerante. A autora argumenta que, mesmo onde não existem diretrizes oficiais sobre religião, o comportamento e atitudes dos agentes escolares levam isso para as escolas. Embora haja perspectivas teóricas e documentos da UNESCO defendendo a escola como um espaço para a construção da tolerância religiosa, a intolerância religiosa está presente na escola e, nesse caso, faria parte da cultura escolar.

Sendo assim, me parece que duas concepções diferentes aparecem nesses dois textos. Uma delas vai no sentido de que as relações para além da sala de aula e a pedagogização desses espaços para o combate ao preconceito é o mais importante. A outra foca mais na relação professor/aluno em sala de aula. É necessária mais leitura sobre o assunto afim de verificar se essa é uma tendência do campo. O presente capítulo buscou trazer uma perspectiva dos principais conceitos e autores que balizam a realização dessa pesquisa. Buscamos mostrar como as transformações no contexto religioso brasileiro mantêm a discussão sobre religião relevante, tanto no âmbito social como no âmbito educacional. O 
crescimento das religiões evangélicas, e sua participação intensa na política brasileira, assim como o crescimento dos declarados "sem religião" trazem à tona a discussão sobre secularização e laicidade no cenário nacional.

Tal discussão foi justamente o segundo ponto tratado nesse capítulo. Buscamos trazer diferentes concepções sobre esses conceitos e refletir sobre sua relevância para pensarmos o contexto escolar. Como a religião se mostra na cultura escolar foi uma de nossas preocupações centrais nessa discussão.

Como possibilidades de pensarmos essa questão no espaço escolar, nos debruçamos sobre a presença do ensino religioso, em uma perspectiva histórica, assim como a reflexão sobre a promoção da tolerância religiosa no contexto educacional.

No próximo capítulo iremos abordar o campo e os sujeitos de pesquisa. 


\section{3 \\ Campo e sujeitos de pesquisa}

Como já citado anteriormente, o trabalho aqui apresentado se constituiu de duas etapas, 2017 e 2018. Na primeira etapa, no ano de 2017, foram aplicados questionários em 10 escolas da Zona Sul do Rio de Janeiro para alunos do $7^{\circ}$ ano do ensino fundamental. Essas escolas foram escolhidas no contexto do Projeto Parceria, exposto na introdução desse trabalho. As escolas pesquisadas, com nomes fictícios, foram: Colégio Água Viva, Colégio Hora da Estrela, Colégio Grande Sertão, Colégio Capitães de Areia, Colégio Iracema, Colégio Brás Cubas, Colégio O Quinze, Colégio Menino Azul, Colégio Auto da Compadecida e Colégio Vidas Secas.

Já na segunda, escolhemos uma das escolas, através de critérios que serão abordados mais à frente, para aprofundar a temática.

Nessa primeira seção desse capítulo traremos dados descritivos desse primeiro universo de escolas, do ano de 2017

Entender o contexto inicial do universo das escolas representadas na pesquisa é importante para indicarmos o processo de escolha da escola Água Viva para o aprofundamento do estudo. Na segunda seção desse capítulo faremos uma descrição mais detalhada do colégio Água Viva e dos alunos e professores entrevistados no contexto da pesquisa. É importante ressaltar, portanto, que nesse universo escolar de 2017 foram feitos questionários, e não entrevistas em cada escola.

\section{1.}

\section{0 universo inicial}

Nessa primeira seção faremos a descrição, das 10 escolas do universo da pesquisa como um todo. No próximo capítulo, ao justificarmos a escolha pela escola Água Viva, faremos a comparação entre as escolas baseado no fator criado para essa pesquisa.

Nessa seção do capítulo três traçaremos um perfil do alunado dessas dez escolas. Como abordado no capítulo anterior, o questionário foi construído pelo grupo de pesquisa tendo como temas gerais o preconceito e a intolerância, e sendo 
dividido em subtemas. No nosso caso, para o contexto dessa pesquisa, iremos nos focar na seção sobre religião, além de dados mais gerais.

\subsection{1.}

\section{Descrição do perfil dos alunos}

Os questionários da primeira onda foram aplicados nas 10 escolas citadas para $1074^{10}$ alunos do $7^{\circ}$ ano. A distribuição de alunos respondentes por escola pode ser visualizada na tabela 3.1

\begin{tabular}{|l|c|c|}
\hline \multicolumn{1}{|c|}{ Nome do Colégio } & Número de Turmas & Quantidade de alunos \\
\hline O Quinze & 3 & 88 \\
\hline Hora da Estrela & 5 & 140 \\
\hline Auto da Compadecida & 4 & 105 \\
\hline Grande Sertão & 4 & 91 \\
\hline Brás Cubas & 3 & 66 \\
\hline Menino Azul & 3 & 96 \\
\hline Iracema & 8 & 216 \\
\hline Capitães de Areia & 7 & 154 \\
\hline Água Viva & 2 & 37 \\
\hline Vidas Secas & 4 & 70 \\
\hline
\end{tabular}

Tabela 3.1 - Distribuição de respondentes por escola

Em relação ao gênero declarado dos estudantes, não há grande diferença entre os números de meninas, 525,49\%, e de meninos, 543, 51\%, como nos mostra o gráfico 3.1 .

\footnotetext{
${ }^{10}$ Em algumas estatísticas o número de alunos pode variar, devido a não responderem o item do questionário referente (respostas ausentes).
} 


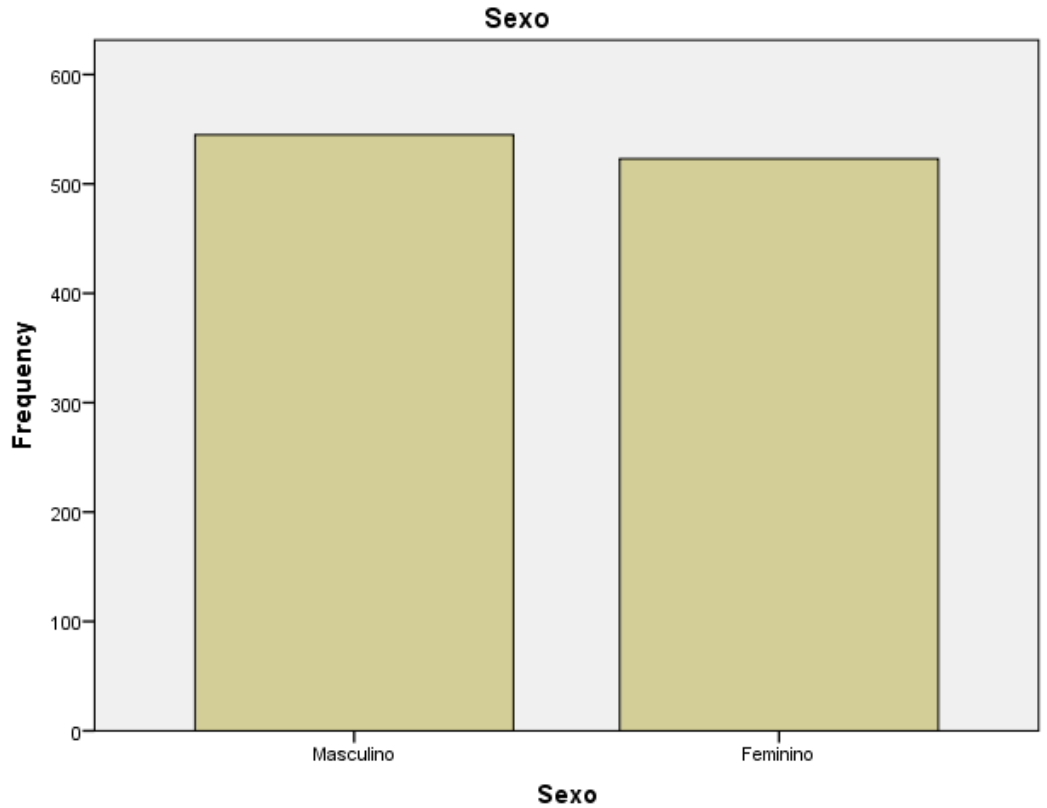

Gráfico 3.1 - Sexo dos alunos

Em relação à raça declarada pelos alunos, como mostra o gráfico 3.2, 45\% dos alunos se consideram pardos, $16 \%$ pretos e $25 \%$ brancos, como números mais relevantes.

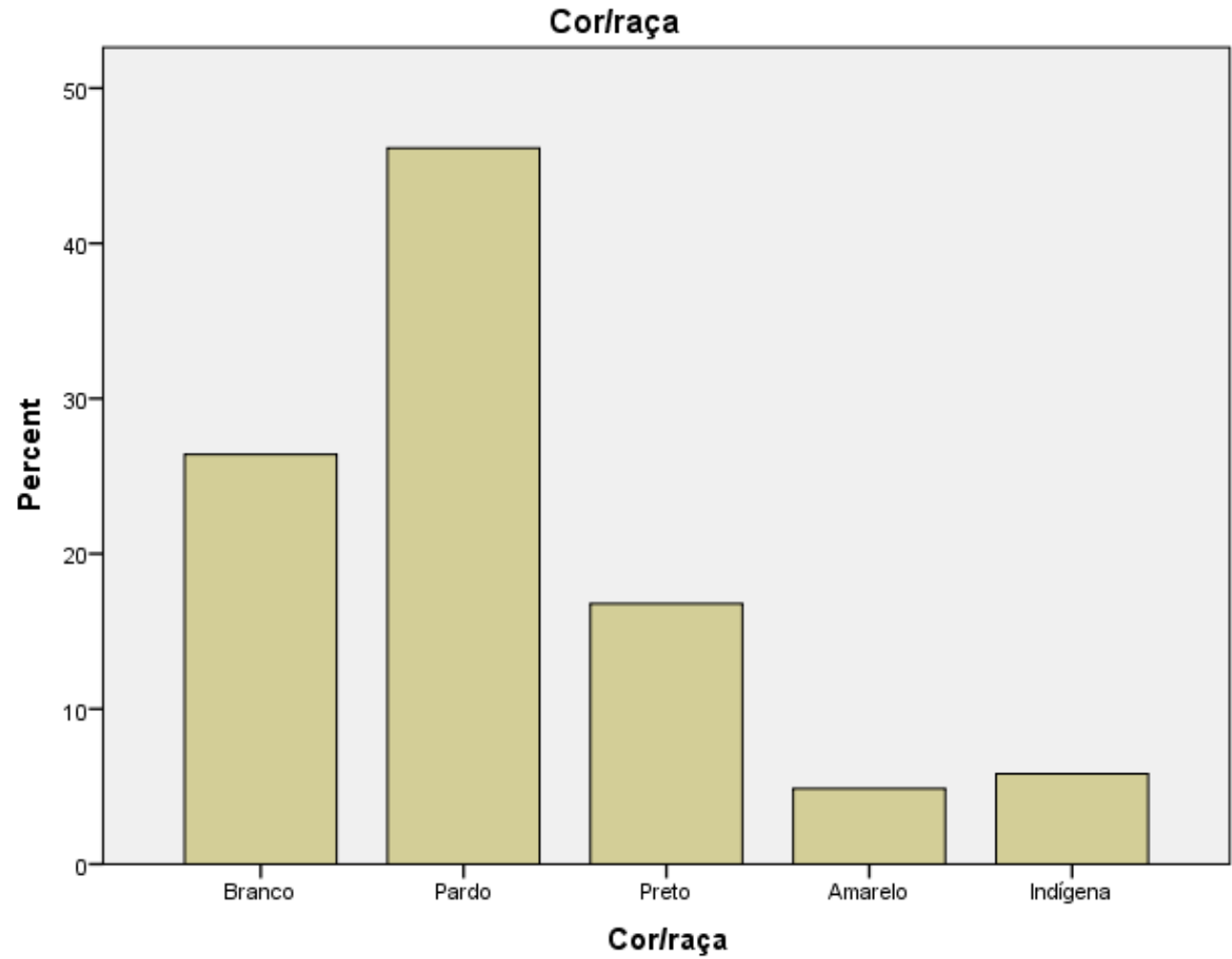

Gráfico 3.2 - Raça dos alunos 
Por esses dados, podemos perceber que $61 \%$ dos alunos se consideram negros ${ }^{11}$, entre pardos e pretos. Comparando com a situação geral do Brasil, segundo o censo 2010, registrou-se uma redução da proporção de brancos, que em 2000 era 53,7\% e em 2010 passou para 47,7\%, e um crescimento de pretos (de $6,2 \%$ para $7,6 \%$ ) e pardos (de $38,5 \%$ para $43,1 \%$ ). Sendo assim, a população preta e parda passou a ser considerada maioria no Brasil (50,7\%). Esses dados mostram que a população estudada por essa pesquisa apresenta um índice de pessoas negras maior do que a média geral brasileira. Isso pode ser explicado pois, apesar de as escolas estudadas estarem localizadas na Zona Sul do Rio de Janeiro, local da cidade com o maior custo de vida, muitos dos alunos são moradores de comunidades. Como no Brasil há uma associação histórica entre a cor da pele e a condição social, esse achado já era esperado.

Em relação ao bairro de moradia $75 \%$ dos alunos declararam serem moradores de alguma comunidade. Outros $10 \%$ se declararam moradores de locais periféricos da cidade, como Duque de Caxias e Costa Barros. Outros 15\% se declaram moradores de bairros da Zona Sul. É importante destacar, no entanto, que mesmo esses que se declararam moradores dos bairros da Zona Sul podem estar se referindo às comunidades.

Em relação à idade dos estudantes, 57\%, 568 estudantes, apresentavam idade entre 12 e 13 anos à época do questionário, idades consideradas ideais para esse ano de escolaridade. Com 14 anos existiam 22,2 \% dos alunos, 13\% com 15 anos e 7,4\% com 16 anos. Esses são os percentuais mais relevantes. Esses dados estão indicados na tabela 3.2.

\begin{tabular}{|c|c|c|}
\hline Idade & Frequência & Percentual \\
\hline 11 & 2 & 0,2 \\
\hline 12 & 217 & 20,2 \\
\hline 13 & 351 & 32,7 \\
\hline 14 & 221 & 20,6 \\
\hline 15 & 130 & 12,1 \\
\hline 16 & 74 & 6,9 \\
\hline 17 & 1 & 0,1 \\
\hline 18 & 1 & 0,1 \\
\hline Total & 998 & 92,9 \\
\hline
\end{tabular}

Tabela 3.2 - Idade dos alunos

\footnotetext{
$\overline{{ }^{11} \text { Seguindo a metodologia do IBGE. }}$
} 
Com esses dados é possível observar que a distorção idade-série nesse contexto é de aproximadamente $20 \%$. A distorção idade-série é a proporção de alunos com mais de 2 anos de atraso escolar. ${ }^{12}$ No Brasil, a criança deve ingressar no $1^{\circ}$ ano do ensino fundamental aos seis anos. Em relação ao contexto da pesquisa, isso significa que o aluno, idealmente, deve estar no $7^{\circ}$ ano do ensino fundamental aos 13 anos. Sendo que, a partir dos 15 anos já é considerada em distorção.

No Brasil, o índice de distorção idade-série é de $12 \%^{13}$, como nos indica o gráfico 3.1, o que coloca as escolas do contexto da pesquisa com uma porcentagem maior do que a média nacional. Já na cidade do Rio de Janeiro, o dado corresponde a $13 \%$.

No que concerne à religião dos estudantes participantes da pesquisa, $31 \%$ acreditam em Deus, mas não tem religião, $33 \%$ dos alunos se declararam católicos, $25 \%$ evangélicos, $3 \%$ ateu, $1 \%$ umbandista e $0,7 \%$ candomblecista.

Esses dados podem ser observados na tabela 3.3:

\begin{tabular}{|c|c|c|}
\hline Religiões & Frequência & Percentual \\
\hline Acredito em Deus, mas não tenho religião & 329 & 30,6 \\
\hline Ateu & 31 & 2,9 \\
\hline Candomblecista & 7 & 0,7 \\
\hline Católico & 350 & 32,6 \\
\hline Espírita Kardecista & 11 & 1,0 \\
\hline Evangélico & 262 & 24,4 \\
\hline Testemunha de Jeová & 12 & 1,1 \\
\hline Umbandista & 10 & 0,9 \\
\hline Outra? & 32 & 3,0 \\
\hline Total & 1044 & 97,2 \\
\hline
\end{tabular}

Tabela 3.3 - Religião dos alunos

Com esses dados, é possível notar que as duas religiões citadas pelos alunos são as mesmas que o IBGE aponta como as religiões com mais adeptos no Brasil, a católica e a evangélica. No entanto, em comparação com os dados nacionais, no contexto da pesquisa a porcentagem de católicos é menor. Enquanto no contexto do país os católicos são mais de $60 \%$ da população, no universo pesquisado

\footnotetext{
${ }^{12}$ Fonte: https://academia.qedu.org.br/censo-escolar/distorcao-idade-serie/. Acesso em 21/03/2019

${ }^{13}$ Fonte: academia.qedu.org.br. acesso em 08/01/19. Os dados citados são produzidos pelo INEP e sistematizados pelo portal Qedu.
} 
correspondem a $33 \%$. Já a porcentagem de evangélicos no país é de $22 \%$ e na pesquisa são $25 \%$.

Como já abordado no segundo capítulo desse trabalho, a origem social também pode nos ajudar a entender esse maior número de evangélicos em relação aos católicos no contexto citado.

Além disso, é importante notar que a porcentagem de estudantes que se declaram sem religião é bem mais expressiva que a pesquisa nacional. Enquanto nas escolas $31 \%$ se declaram que acreditam em Deus, mas não tem religião, na pesquisa do IBGE apenas $8 \%$ se declaram sem religião, já inclusos os ateus e agnósticos nesse percentual.

Um outro dado relevante em relação à religiosidade desses alunos é em relação à frequência em templos religiosos. 27,7\% afirmam nunca frequentarem templos religioso; 25,7 \% algumas vezes por ano; 21,9\% uma vez na semana; 13,7 $\%$ mais do que uma vez na semana e $9,4 \%$ uma ou mais vezes por mês. É interessante olhar, em conjunto, a alta porcentagem dos estudantes que se declaram sem religião, assim como o elevado número de respondentes que dizem nunca irem a templos religiosos. É possível pensar nisso como um indicativo da menor relevância da religião na vida dos mais jovens.

É interessante notar, no entanto, como esse dado se transforma ao analisarmos a frequência nos templos por religião, como visto na tabela 3.4.

\begin{tabular}{|l|r|r|r|r|r|}
\hline \multicolumn{1}{|c|}{ Religiões } & $\begin{array}{c}\text { Mais do que } \\
\text { uma vez por } \\
\text { semana }\end{array}$ & $\begin{array}{c}\text { Uma vez por } \\
\text { semana }\end{array}$ & $\begin{array}{c}\text { Duas ou } \\
\text { mais vezes } \\
\text { por mês }\end{array}$ & $\begin{array}{c}\text { Algumas } \\
\text { vezes por ano }\end{array}$ & Nunca \\
\hline $\begin{array}{l}\text { Acredito em Deus, mas } \\
\text { não tenho religião }\end{array}$ & $6,4 \%(21)$ & $12,8 \%(42)$ & $7,9 \%(26)$ & $30,1 \%(99)$ & $42,2 \%(139)$ \\
\hline Ateu & $3,2 \%(1)$ & $3,2 \%(1)$ & $0,0 \%(0)$ & $16,1 \%(5)$ & $77,4 \%(24)$ \\
\hline Candomblecista & $28,6 \%(2)$ & $14,3 \%(1)$ & $14,3 \%(1)$ & $42,9 \%(3)$ & $0,0 \%(0)$ \\
\hline Católicos & $7,2 \%(25)$ & $30,1 \%(105)$ & $11,7 \%(41)$ & $32,4 \%(113)$ & $18,6 \%(65)$ \\
\hline Espírita Kardecista & $0,0 \%(0)$ & $54,5 \%(6)$ & $27,3 \%(3)$ & $0,0 \%(0)$ & $18,2 \%(20$ \\
\hline Evangélico & $33,1 \%(85)$ & $23,7 \%(61)$ & $8,2 \%(21)$ & $18,7 \%(48)$ & $16,3 \%(42)$ \\
\hline Testemunhas de Jeová & $25,0 \%(3)$ & $41,7 \%(5)$ & $16,7 \%(2)$ & $0,0 \%(0)$ & $16,7 \%(2)$ \\
\hline Umbandista & $20,0 \%(2)$ & $20,0 \%(2)$ & $30,0 \%(3)$ & $20,0 \%(2)$ & $10,0 \%(1)$ \\
\hline Outro & $19,4 \%(6)$ & $22,6 \%(7)$ & $9,7 \%(3)$ & $16,1 \%(5)$ & $32,3 \%(10)$ \\
\hline \multicolumn{1}{|c|}{ Total } & $14,0 \%(145)$ & $22,2 \%(230)$ & $9,6 \%(100)$ & $26,5 \%(275)$ & $27,5 \%(285)$ \\
\hline
\end{tabular}

Tabela 3.4 - Frequência em templo religioso por religião 
Quando olhamos para esses dados distribuídos por religião vemos uma clara diferença dos alunos que se declaram evangélicos quando comparados aos de outras religiões. Entre os evangélicos se apresenta a maior porcentagem dos que declaram irem ao templo mais do que uma vez por semana, com 33,3\%. Quando olhamos esses dados para os católicos vemos uma queda para apenas 7,2\%. No outro extremo da tabela também podemos diferenciar os evangélicos. Apenas 16,3\% dizem nunca irem a templos religiosos. Os católicos são 18\%. No entanto, quando olhamos para a coluna dos que vão uma vez por semana, os católicos são $30 \%$ e os evangélicos $23 \%$. Tais dados indicam uma relação diferente com a religião entre alunos evangélicos e católicos.

$\mathrm{Na}$ próxima seção desse capítulo iremos nos aprofundar na descrição da escola escolhida para a continuação da pesquisa no ano de 2018.

\section{2. \\ O Colégio Água Viva}

O Colégio Água Viva está localizado no bairro de Ipanema, Zona Sul do Rio de Janeiro, próximo a uma estação de metrô, das praias de Ipanema e do Arpoador, de shopping centers e das comunidades Pavão, Pavãozinho e Cantagalo. No contexto da rede municipal da cidade do Rio de Janeiro, é considerada uma escola de pequeno porte. De acordo com a direção da escola, a escola atende ao ensino fundamental I e ao ensino fundamental II, nos turnos da manhã e da tarde. No ano de 2018 estavam matriculados 374 alunos. Nas turmas de $1^{\circ}$ ao $5^{\circ}$ ano estavam matriculados, no ano de 2018, 160 crianças. Já nas turmas do $6^{\circ}$ ao $9^{\circ}$ ano, estavam matriculados 209 estudantes, além de 5 matrículas de educação especial.

No $8^{\circ}$ ano em 2018, série dos estudantes participantes da segunda parte da coleta dos dados, estavam matriculados 52 alunos, divididos em duas turmas, 801 de manhã e 802 à tarde. A turma 801 contava com 30 alunos, enquanto na 802 tinham 22 alunos.

Sua estrutura física é constituída de um prédio de três andares. No térreo se encontra o refeitório, que também faz às vezes de pátio no recreio. Neste mesmo piso estão a sala da direção, a sala dos professores e a cozinha. Nesse espaço ficam fixados murais com cartazes de avisos e lembretes, como sobre a renovação 
do bolsa família, vale transporte dos alunos (Riocard) e datas de provas, entre outros comunicados. $\mathrm{Na}$ parte externa existe um pequeno pátio, um estacionamento, e uma quadra para a prática de educação física.

No segundo andar estão as salas de aula do ensino fundamental II, no total de quatro, uma para cada turma. No último andar ficam as salas do fundamental I, assim como a sala de leitura e o laboratório de informática, com cerca de 10 computadores. Segundo dados do censo 2017, a escola utiliza 9 das 11 salas disponíveis no espaço. Todas as salas de aula possuíam aparelhos de arcondicionado e. As salas não são equipadas com projetores multimídia (datashow).

Em relação à estrutura organizacional da escola, a direção era formada por uma diretora-geral, e uma diretora adjunta. Também estavam presentes no espaço escolar os funcionários de apoio, inspetores e porteiros. A escola conta, no geral, com 37 funcionários, entre professores, direção e apoio, segundo dados do censo escolar.

A sala dos professores era local de concentração dos docentes nos momentos que antecediam a entrada em sala de aula e no momento do intervalo. Os professores geralmente conversavam sobre as turmas, a escola e, muitas vezes, também sobre casos particulares de alunos. Outras vezes os professores conversavam sobre assuntos que não se limitavam somente ao contexto escolar, como política e futebol. O clima na sala dos professores era amistoso. Não presenciamos no tempo de observação nenhum conflito sério, apenas opiniões divergentes sobre os mais diversos assuntos. A direção da escola não costumava ficar na sala dos professores.

Certa vez, por exemplo, na sala dos professores, presenciamos uma conversa sobre um certo aluno, que se declarava transexual. Essa discussão inicial sobre o comportamento desse aluno em sala de aula e no contexto escolar, desencadeou toda uma discussão sobre gênero e sexualidade, inclusive envolvendo parâmetros religiosos. Essa situação será melhor abordada mais à frente. Mas é ilustrativo da variedade de assuntos tratados naquele ambiente.

Além dos professores, outros atores escolares também frequentam o ambiente da sala dos professores. Muitas vezes, durante minhas observações, os funcionários de apoio se encontravam na sala dos professores. Mas também os próprios alunos o faziam. Algumas alunas do $9^{\circ}$ ano nutriam uma relação de 
amizade com umas das professoras acompanhadas por essa pesquisa. Por essa razão, em algumas ocasiões essas alunas ficavam na sala dos professores conversando com essa professora. Não presenciamos nenhum desconforto com a presença de alunas naquele espaço.

Não presenciei, durante as observações, muitos casos de atrasos por parte dos docentes. Os professores observados pela pesquisa, de história e de ciências, sempre se encontravam no ambiente escolar antes do horário programado para o início das aulas, de manhãs às 7 h30 e de tarde $13 \mathrm{~h} 30$. No entanto, o atraso dos alunos era um problema mais constante. Diversas vezes havia menos da metade da turma ao iniciar a aula. Uma grande parte dos alunos chegava até 15 minutos após o horário de início das aulas. Os professores lidavam bem com essa situação. Na maior parte dos casos atrasavam um pouco o início das aulas para que a turma enchesse.

O maior espaço de interação entre os alunos era o refeitório da escola. Antes de subirem para as salas de aula os alunos ficavam no refeitório sentados, conversando e ouvindo música. No meu tempo de observação presenciei algumas discussões entre os alunos, mas nada que tenha se revertido em agressão física.

$\mathrm{Na}$ hora do intervalo os alunos também desciam para o refeitório para fazerem a sua refeição e passar o tempo antes de retornarem para as suas salas de aula. Eles desciam e faziam a fila na porta da cozinha para pegar a refeição, se sentavam para comer e interagiam entre si, em grupos muito parecidos com os que existiam no momento da entrada. A quadra não era utilizada pelos alunos no momento do intervalo, apenas na educação física.

$\mathrm{Na}$ descida para o recreio as salas eram trancadas e todos os alunos saiam. Mesmo com as salas trancadas, alguns estudantes preferiam levar o material com eles para o intervalo. Alegavam que poderiam ser furtados por colegas que voltassem para a sala de aula antes deles. Outros preferiam deixar o material nas carteiras para guardar o mesmo lugar na volta do intervalo.

É interessante notar que, apesar da convivência pacífica descrita acima e, embora não haja casos de violência física, a desconfiança é constante. Ao fechar as salas, a escola não age para evitar que essa desconfiança diminua, apenas para que não haja casos de furto. Isso mostra como é difícil, mesmo para a escola, romper ou desconstruir, certos tipos de violência que os alunos lidam no dia-a-dia. 
Durante o intervalo, estudantes utilizam diversas formas de descontração no pátio, como ouvir músicas individualmente, ou compartilhando o fone com outros colegas. Além disso, alguns jogavam cartas, ou simplesmente ficavam sentados conversando. Muitos estudantes ficavam em seus celulares e aparelhos eletrônicos. No ambiente do refeitório, onde os alunos passavam a maior parte do intervalo, existia também uma mesa de "totó", onde alguns alunos se revezavam ao jogar. É importante notar que apenas os meninos praticavam o jogo. As meninas costumavam ficar em grupos conversando, ouvindo música e mexendo em seus celulares.

As diferentes identidades se expressavam neste espaço, sem que necessariamente entrassem em conflito, mas também sem muita interação entre grupos de perfis distintos Durante o período de observação foi possível perceber que eram poucos os estudantes isolados no pátio, mantendo-se organizados em pequenos grupos conversando e interagindo entre si. São grupos formados só por meninos, só por meninas ou mistos.

Durante o meu período de convivência na escola, presenciei a organização da Feira Cultural. Essa feira era organizada pela escola e os professores ficavam responsáveis por orientar os trabalhos das turmas. Os alunos das turmas deveriam se envolver. No entanto, alguns grupos se empolgavam mais do que outros na mesma turma.

A turma 801 organizou uma dança coreografada sobre a China. O professor de história deu sugestões quanto ao que eles poderiam fazer e a professora de ciências cedeu por vezes o espaço de sua aula para os alunos poderem ensaiar. O local de ensaio também era o refeitório.

\subsection{1.}

\section{Os estudantes do Colégio Água Viva}

O Colégio Água Viva possuía, durante o ano de 2018, 2 turmas de $8^{\circ}$ ano, uma no turno da manhã e outra no turno da tarde. As turmas de $8^{\circ}$ ano foram escolhidas devido à continuidade com a pesquisa anterior, que aplicou o questionário para turmas de $7^{\circ}$ ano.

As observações das duas turmas foram realizadas entre março e agosto de 2018. Devido aos conteúdos curriculares das disciplinas do $8^{\circ}$ ano, optamos por 
observar as aulas de ciências e história, já que abordariam temas que, potencialmente, se aproximariam de questões religiosas (como reprodução humana e a Reforma Protestante, por exemplo). Contudo, na turma 801 a professora de ciências não aceitou ter sua aula observada, e apenas assistimos às aulas de história. Já na 802, observamos as duas disciplinas. Em ambas as turmas o professor de história era o mesmo.

Dessa forma, observamos as aulas de dois professores, em duas turmas. Além disso, fizemos entrevistas com os três professores, dois de ciências e um de história, com a direção da escola e com quatro alunos, todos da 802.

Já o questionário, foi aplicado nas duas turmas de oitavo ano, com os alunos presentes no dia da aplicação. No total, foram aplicados 36 questionários, sendo 20 na 801 e 16 na 802. É preciso considerar que esse número se deveu, além da falta de alguns alunos no dia da aplicação, à evasão dos alunos durante o ano.

A escola atende, majoritariamente, jovens moradores de favelas próximas e do bairro da escola. Os bairros dos estudantes pesquisados são apresentados na Tabela 3.5. é possível perceber que mais da metade dos estudantes $(80,4 \%)$ mora em localidades da Zona Sul (Rocinha, Vidigal, Copacabana, Ipanema).

\begin{tabular}{|l|r|r|}
\hline \multicolumn{1}{|c|}{ Escolas } & Frequência & Percentual \\
\hline Caju & 1 & 2,8 \\
\hline Catete & 1 & 2,8 \\
\hline Copacabana & 10 & 27,8 \\
\hline Ipanema & 9 & 30,6 \\
\hline Irajá & 1 & 2,8 \\
\hline Rocinha & 6 & 16,7 \\
\hline Vidigal & 3 & 8,3 \\
\hline Vila da Aeronáutica & 1 & 2,8 \\
\hline \multicolumn{1}{|c|}{ Total } & 36 & 100,0 \\
\hline
\end{tabular}

Tabela 3.5 - Distribuição dos estudantes do Água Viva participantes da pesquisa de acordo com o bairro em que residem.

O perfil religioso dos estudantes participantes da pesquisa pode ser visto na tabela 3.6. Primeiramente, chama a atenção o elevado percentual de estudantes que declaram que acreditam em Deus, mas não tem religião, com mais de $40 \%$, indicando a preferência de muitos dos jovens pesquisados por uma fé não 
institucionalizada. Outro dado interessante é o empate entre católicos e evangélicos, com $25 \%$ cada um. O que mostra uma diminuição da porcentagem de católicos em relação ao contexto nacional.

\begin{tabular}{|c|c|c|}
\hline Religiões & Frequência & Percentual \\
\hline Acredito em Deus, mas não tenho religião & 15 & 41,7 \\
\hline Ateu & 1 & 2,8 \\
\hline Católico & 9 & 25,0 \\
\hline Evangélico & 9 & 25,0 \\
\hline Outro & 1 & 2,8 \\
\hline Total & 35 & 100,0 \\
\hline
\end{tabular}

Tabela 3.6 - Distribuição dos estudantes pesquisados do Colégio Água Viva de acordo com seus grupos religiosos

Em relação ao sexo, são 58,3\% do sexo masculino e $41,7 \%$ do feminino (Tabela 3.7). Sobre a cor/raça (Tabela 3.8), 38,9\% dos estudantes se consideram pardos, $22,2 \%$ brancos, $30,6 \%$ pretos, $5,6 \%$ amarelos $^{14}$ e $2,8 \%$ indígenas. No que concerne à idade ${ }^{15}$ (Tabela 3.9),19,4\% dos educandos tinha treze anos, 44,4\% tinham quatorze anos, $33,3 \%$ quinze anos e 2,8\% com dezesseis anos.

\begin{tabular}{|c|c|c|}
\hline Sexo & Frequência & Percentual \\
\hline Masculino & 21 & 58,3 \\
\hline Feminino & 15 & 41,7 \\
\hline Total & 36 & 100,0 \\
\hline
\end{tabular}

Tabela 3.7 - Sexo dos estudantes participantes da pesquisa no Colégio Água Viva

\footnotetext{
${ }^{14}$ A categoria "amarelo" no Censo Demográfico é utilizada para agrupar cidadãos de ascendência asiática. Em nossas observações, não encontramos nenhum estudante que parecesse se enquadrar nesse caso, mesma situação da alternativa "indígena". A hipótese mais plausível, baseada nas notas de campo colhidas durante a aplicação do questionário, é que os educandos que marcaram esta alternativa basearam-se na visualização da cor da sua pele, que possivelmente seria considerada "parda". Contudo, optamos por manter a autodeclaração dos participantes.

15 Tomamos como data de referência 31/12/2018.
} 


\begin{tabular}{|l|c|c|}
\hline \multicolumn{1}{|c|}{ Cor } & Frequência & Percentual \\
\hline Branco & 8 & 22,2 \\
\hline Pardo & 14 & 38,9 \\
\hline Preto & 11 & 30,6 \\
\hline Amarelo & 2 & 5,6 \\
\hline Indígena & 1 & 2,8 \\
\hline \multicolumn{1}{|c|}{ Total } & 36 & 100,0 \\
\hline
\end{tabular}

Tabela 3.8 - Cor/raça dos estudantes participantes da pesquisa no Colégio Água Viva

\begin{tabular}{|c|c|c|}
\hline \multicolumn{1}{|c|}{ Idade } & Frequência & Percentual \\
\hline 13 & 7 & 19,4 \\
\hline 14 & 16 & 44,4 \\
\hline 15 & 12 & 33,3 \\
\hline 16 & 1 & 2,8 \\
\hline Total & 36 & 100,0 \\
\hline
\end{tabular}

Tabela 3.9 - Idade dos estudantes participantes da pesquisa no Colégio Água Viva

Em se tratando dos alunos entrevistado, o aluno A1, 15 anos, é branco, sem religião. A2, parda, 14 anos, é evangélica e frequenta a Assembleia de Deus. A aluna A3, parda, 14 anos, é evangélica da Assembleia de Deus do Leblon. O aluno A3, pardo, evangélica, da igreja Paz e Vida. A aluna A4 é negra, 14 anos, é católica. Os perfis desses alunos serão discutidos com maiores detalhes mais à frente, ao analisarmos suas entrevistas.

\subsection{2. \\ Os professores do Colégio Água Viva}

No Colégio Água Viva, observamos as aulas de dois professores, uma de ciências e um de história, em duas turmas de $8^{\circ}$ ano. Como discutido anteriormente, esse número se deu devido ao mesmo professor de história ser das duas turmas, e uma professora de ciências não aceitar a observação. A professora que não aceitou a observação (P3), no entanto, aceitou ser entrevistada e, por isso, entra nesse breve perfil. O perfil dos docentes pesquisados foi construído a partir de uma ficha de identificação por eles preenchida (Apêndice 4).

P1 é professor de história, tem 56 anos de idade, 28 anos de magistério e 20 anos de atuação no oitavo ano e treze no Colégio Água Viva. Atualmente atua em 
uma escola estadual, além da Água Viva. Possui licenciatura em Ciências Sociais pela Universidade do Estado do Rio de Janeiro (UERJ), pós-graduação em História das Relações Internacionais, pela UERJ. Em sua entrevista, P1 diz que foi criado como católico, mas que agora não tem religião. Não ocupava nenhum cargo de coordenação ou direção. De uma maneira geral, apresentava um bom relacionamento com os estudantes, demonstrando paciência e bastante domínio do conteúdo ensinado. Por vezes se irritava com a turma e elevava o tom da voz. Mas, no geral, os alunos o respeitavam e realizavam as tarefas propostas. Suas aulas foram todas expositivas, utilizando apenas o quadro e, com menor frequência, usava o livro didático, pedindo aos alunos que lessem certos trechos e respondessem perguntas sobre. A disciplina de história não possui apostila da prefeitura.

A professora $\mathrm{P} 2$, de biologia, tem 45 anos de idade, 23 anos de magistério, sendo 20 como professora do oitavo ano e 12 anos no Água Viva. Atualmente, trabalha nesta escola e mais três, uma municipal e duas estaduais. Possui licenciatura e bacharelado em Ciências Biológicas pela Universidade Federal Fluminense (UFF) e pós-graduação lato sensu em Patologia Clínica pela Universidade Souza Marques. Ela se autodeclara evangélica desde o nascimento, sendo bem atuante na igreja, organizando grupos e fazendo parte da escola. Ela é uma figura muito participativa na escola, interagindo com muitos colegas professores, membros da direção, funcionários e alunos. Não ocupava nenhum cargo de coordenação.

Em suas aulas, procurava fazer aulas expositivas e de desenho. A prefeitura fornece aos alunos cadernos de desenho para as aulas de artes. Como a habilitação presente para o oitavo ano era música, a professora de ciências utilizava esse caderno para realizar desenhos científicos. De acordo com o conteúdo do oitavo ano, eram desenhados partes do corpo humano, desde a célula até os órgãos. A professora utilizava constantemente a apostila imposta pela prefeitura. Apesar de ter o livro didático na escola, esse não era utilizado.

Já a docente P3 tem 61 anos de idade, 30 de magistério, aproximadamente 6 meses nesta escola e um ano trabalhando com turmas de oitavo. Além de professora no Água Viva, também trabalha em uma escola estadual. É licenciada em Ciências Biológicas pela Universidade de São Paulo (USP) e mestrado e doutorado, também pela USP, em psicologia. Quanto à religião, se diz católica de 
nascimento, mas que já leu sobre budismo e espiritismo. Por fim, se declara espiritualista. A professora pouco interagia com os colegas professores, funcionários e alunos. Na hora da saída e do intervalo, costumava sentar sozinha. Como já dito, não foi possível a observação em sala de aula dessa docente devido à sua exigência de ler as anotações do caderno de campo.

A distribuição das aulas durante os períodos do dia é feita de maneira tradicional, isto é, diferentes tempos de aula de 50 minutos, com diferentes disciplinas sendo ofertadas no mesmo dia. Os professores observados seguem o currículo prescrito proposto pela prefeitura e seu calendário da avaliação.

Durante o nosso tempo de observação, não houve momentos que não tivessem aulas por algum motivo repentino, como falta de água ou luz. Também não presenciamos episódios de faltas de professores, nem os que observamos e nem os restante do corpo docente presente nos dias em que fizemos nossas observações. Como relatado anteriormente, não presenciamos episódios de violência física entre os alunos, mas sim verbal.

Neste capítulo buscamos fazer uma análise do perfil dos alunos, desde o início do processo de 2017, com a raça, sexo e religião. Também buscamos descrever o campo de pesquisa e as relações nesse espaço escolar. No próximo capítulo iremos analisar mais atentamente as respostas dos alunos pesquisados ao questionário de 2018. 


\section{4 Análise dos questionários dos alunos da escola Água Viva}

Nesse capítulo, primeiramente, justificaremos a escolha da escola Água Viva como lócus da coleta de dados qualitativos dessa pesquisa. Posteriormente, analisaremos as respostas aos questionários dos alunos do $8^{\circ}$ ano da Escola Água Viva de 2018.

\section{1. A construção do fator e a escolha da escola Água Viva}

A escolha da referida escola se deu a partir dos resultados dos questionários aplicados em todo o universo de escolas do ano de 2017. Tais resultados foram usados para construir um fator de intolerância religiosa. Construído esse índice, foi possível fazer um ranking com as escolas que tiveram as respostas que tendiam a cenários mais tolerantes e mais intolerantes. A escola que obteve o maior índice de respostas intolerantes de seus alunos foi a escola Água Viva.

A construção do fator se deu através de uma análise fatorial exploratória. Segundo Figueiredo Filho (2010, p.161), o objetivo da análise fatorial é identificar variáveis que "caminham juntas", ou seja, variáveis que apresentam a mesma estrutura subjacente

\footnotetext{
"Tecnicamente, isso pode ser implementado através da análise fatorial. A principal função das diferentes técnicas de análise fatorial é reduzir uma grande quantidade de variáveis observadas a um número reduzido de fatores. Os fatores representam as dimensões latentes (construtos) que resumem ou explicam o conjunto de variáveis observadas"
}

O objetivo inicial da nossa análise fatorial era o de chegar a um fator que indicasse um índice de "intolerância religiosa" dos participantes da pesquisa. A partir das 10 questões referentes à religião expostas no questionário, foi realizada uma análise fatorial exploratória com uso do software SPSS.

$\mathrm{Na}$ primeira rodagem da análise fatorial percebemos que as variáveis não mediam apenas um fator, mas a princípio 3. As questões 1 e 5 se ligaram a dois fatores diferentes, e por isso foram excluídas. Já a questão 10 não se ligou a nenhum fator.

Foi realizada uma segunda análise, dessa vez excluindo-se as variáveis 1, 5 e 10, obtendo-se dois fatores. Em uma primeira análise identificamos que o fator 1 
se referia a afirmações que tratavam de intolerância religiosa de uma maneira geral. Já o fator 2 se relacionava a afirmações que tratavam especificamente de evangélicos. No entanto, o fator 2 não foi usado para essa pesquisa pois sua confiabilidade medida por meio do cálculo do Alfa de Crombach ficou em 0,264, longe do valor aproximado de 0,7, considerado um valor razoável (FIELD, 2009).

Por outro lado, o fator 1 apresentou validade e adequação aceitáveis, sendo seu Alfa de Cronbach 0,699 e KMO de 0,740. Segundo Dini et al (2014), os valores de KMO mostram a proporção da variância que os indicadores apresentam em comum, sendo que são razoáveis valores de KMO entre 0,6 e 0,7, são considerados médios valores de KMO entre 0,7 e 0,8, bons para KMO entre 0,8 e 0,9 e muito bons para KMO maiores que 0,9. Já o Alfa de Crombach deve ter, segundo os autores, um valor próximo ou maior do que 0,7. A tabela 4.1 mostra os valores a as variáveis das questões utilizadas para a construção do fator.

\begin{tabular}{|l|c|}
\hline & Componente \\
\cline { 2 - 2 } & 1 \\
\hline Gefé 2: Quem não acredita em Deus vai para o inferno. & 0,746 \\
Gefé 4: O candomblé é uma religião do demônio. & 0,689 \\
Gefé 8: Quem acredita em imagens de santo não vai para o & 0,750 \\
céu. & 0,721 \\
Gefé 9: Só existe uma religião verdadeira. & \\
\hline
\end{tabular}

Tabela 4.1 - Construção do fator de comparação

Métodos: Análise dos componentes principais.

$\mathrm{KMO}=0,747$

Variância explicada: $52,8 \%$

Alfa de Cronbach: 0,699

A partir do valor do fator obtido por cada estudante, calculamos as médias de cada escola. As médias podem ser verificadas na tabela 4.2. Como pode ser notado, o colégio Água Viva teve o maior score no índice entre os colégios pesquisados. 


\begin{tabular}{|l|r|r|r|}
\hline \multicolumn{4}{|c|}{ Fator: Intolerância religiosa } \\
\hline \multicolumn{1}{|c|}{ Escola } & Média & $\mathrm{N}$ & \multicolumn{1}{c|}{ Desvio padrão } \\
\hline Água Viva &, 3257311 & 35 & 1,08453194 \\
\hline Capitães de Areia &, 2759929 & 145 &, 99421630 \\
\hline Brás Cubas &, 2017705 & 61 & 1,05082962 \\
\hline Hora da Estrela &, 1599601 & 131 & 1,02226196 \\
\hline Menino Azul &,- 0499455 & 91 &, 98018748 \\
\hline Grande Sertão &,- 0901260 & 89 &, 92858787 \\
\hline Iracema &,- 0973008 & 201 &, 97562792 \\
\hline Auto da Compadecida &,- 1609257 & 101 &, 97100904 \\
\hline O Quinze &,- 1876104 & 87 &, 95914163 \\
\hline Vidas Secas &,- 2938676 & 68 &, 96540731 \\
\hline \multicolumn{1}{|c|}{ Total } & 000000000 & 1009 & 1,00000000 \\
\hline
\end{tabular}

Tabela 4.2 - Classificação das escolas segundo o fator gerado

Além de usarmos o fator criado para escolhermos a escola, também utilizamos a pergunta "Você já sofreu preconceito na escola por causa de sua religião ou por não ter religião?". Como pode ser visto na tabela 4.3 , a menor porcentagem de alunos que disseram nunca terem sofrido preconceito por esse motivo foi justamente no colégio Água Viva, o que corrobora o indicado pelo fator. A escola apresentou $76 \%$ de alunos que disseram nunca terem sofrido preconceito por essa razão. O colégio que apresentou a maior porcentagem nessa questão foi O Quinze, com 92\% marcando "nunca".

\begin{tabular}{|l|r|r|r|r|}
\hline \multicolumn{1}{|c|}{ Escola } & \multicolumn{1}{c|}{ Nunca } & Poucas vezes & Muitas vezes & \multicolumn{1}{c|}{ Sempre } \\
\hline Quinze & $92,0 \%$ & $3,4 \%$ & $4,5 \%$ & $0,0 \%$ \\
\hline Hora da Estrela & $86,5 \%$ & $10,6 \%$ & $0,7 \%$ & $2,1 \%$ \\
\hline Auto da Compadecida & $80,2 \%$ & $15,1 \%$ & $2,8 \%$ & $1,9 \%$ \\
\hline Grande Sertão & $91,3 \%$ & $6,5 \%$ & $2,2 \%$ & $0,0 \%$ \\
\hline Brás Cubas & $79,4 \%$ & $11,8 \%$ & $8,8 \%$ & $0,0 \%$ \\
\hline Menino Azul & $90,5 \%$ & $9,5 \%$ & $0,0 \%$ & $0,0 \%$ \\
\hline Iracema & $89,3 \%$ & $7,4 \%$ & $1,9 \%$ & $1,4 \%$ \\
\hline Capitães de Areia & $91,6 \%$ & $5,2 \%$ & $1,9 \%$ & $1,3 \%$ \\
\hline Água Viva & $76,3 \%$ & $18,4 \%$ & $2,6 \%$ & $2,6 \%$ \\
\hline Vidas Secas & $81,7 \%$ & $9,9 \%$ & $4,2 \%$ & $4,2 \%$ \\
\hline
\end{tabular}

Tabela 4.3 - Porcentagem de respostas à pergunta "Você já sofreu preconceito na escola por causa de sua religião ou por não ter religião?" 
Entre os anos de 2017 e 2018 as turmas pesquisadas sofreram alterações quanto à sua população. Na turma $801,36 \%$ dos alunos estavam na escola durante o ano de 2017, ou seja, foram respondentes tanto do questionário 2017 quanto do questionário 2018. Já na turma 802, alunos nessa situação correspondem a 66,6\%.

No total, aproximadamente 54\% dos alunos participantes da pesquisa estavam presentes em 2017. Devido a esse percentual, não é possível fazer a comparação estatística entre os anos de 2017 e 2018, pois não foram os mesmos sujeitos, estritamente, que responderam nos dois momentos. No entanto, afim de entendermos melhor o cenário inicial da pesquisa, destacamos as respostas às questões sobre religião dos alunos do universo da pesquisa do ano de 2017 , de todas as escolas (tabela 4.4).

\begin{tabular}{|l|r|r|r|r|}
\hline \multicolumn{1}{|c|}{ Afirmativas } & \multicolumn{1}{|c|}{$\begin{array}{c}\text { Discordo } \\
\text { muito }\end{array}$} & Discordo & Concordo & $\begin{array}{c}\text { Concordo } \\
\text { muito }\end{array}$ \\
\hline Todas as pessoas têm que ter uma religião. & $29,7 \%$ & $50,5 \%$ & $14,5 \%$ & $5,3 \%$ \\
\hline Quem não acredita em Deus vai para o inferno. & $34,7 \%$ & $37,3 \%$ & $19,1 \%$ & $8,9 \%$ \\
\hline $\begin{array}{l}\text { Todos os evangélicos são fanáticos (radicais, } \\
\text { exagerados). }\end{array}$ & $30,8 \%$ & $51,3 \%$ & $13,9 \%$ & $4,0 \%$ \\
\hline O candomblé é uma religião do demônio. & $24,9 \%$ & $43,5 \%$ & $22,7 \%$ & $8,9 \%$ \\
\hline $\begin{array}{l}\text { Alunos do candomblé e da umbanda podem usar } \\
\text { suas guias (colares de santo) na escola. }\end{array}$ & $15,0 \%$ & $25,2 \%$ & $49,6 \%$ & $10,2 \%$ \\
\hline $\begin{array}{l}\text { Estudantes evangélicos podem fazer trabalhos } \\
\text { escolares sobre religiões africanas. }\end{array}$ & $5,7 \%$ & $12,6 \%$ & $63,0 \%$ & $18,8 \%$ \\
\hline É melhor acreditar na Bíblia do que na Ciência & $13,4 \%$ & $33,9 \%$ & $31,8 \%$ & $20,9 \%$ \\
\hline $\begin{array}{l}\text { Quem acredita em imagens de santo não vai } \\
\text { para o céu. }\end{array}$ & $28,5 \%$ & $52,7 \%$ & $13,7 \%$ & $5,1 \%$ \\
\hline Só existe uma religião verdadeira. & $33,8 \%$ & $49,2 \%$ & $11,0 \%$ & $6,0 \%$ \\
\hline $\begin{array}{l}\text { É bom quando a professora reza na aula com os } \\
\text { alunos. }\end{array}$ & $12,2 \%$ & $34,7 \%$ & $43,9 \%$ & $9,3 \%$ \\
\hline
\end{tabular}

Tabela 4.4 - Respostas ao questionário 2017

Na tabela 4.4 podemos notar que a maior parte dos alunos responde de maneira tolerante às afirmações do questionário. No entanto, podemos fazer alguns destaques. Ao somarmos as colunas de "concordo" e "concordo muito" obtemos que, de um universo de 1000 alunos $30 \%$ concordam com a frase "quem não acredita em Deus vai para o inferno", 20\% acreditam que todas as pessoas têm que ter uma religião, $17 \%$ que só existe uma religião verdadeira. Outros $30 \%$ concordam que o candomblé é uma religião do demônio. Tais dados apontam que, 
apesar de a maior parte responder de forma tolerante, a intolerância está presente na escola.

Outra questão interessante é quanto à crença. Na afirmação "É melhor acreditar na Bíblia do que na Ciência”, 50,2\% expressaram concordância. Em um universo de 55\% de cristãos, isso mostra uma valorização da bíblia em detrimento da ciência como fonte de crença.

Um terceiro dado interessante é quanto ao hábito de rezar em sala de aula. Em relação à afirmação "É bom quando a professora reza na aula com os alunos", $52 \%$ apresentaram concordância. Esse dado indica que há uma reação positiva em relação à presença de momentos de oração no espaço escolar por parte desses alunos.

Em seguida, analisamos as respostas dos alunos do colégio Água Viva ao questionário de 2017, como podemos ver na tabela 4.5.

\begin{tabular}{|l|r|r|r|r|}
\hline \multicolumn{1}{|c|}{ Afirmativas } & $\begin{array}{c}\text { Discordo } \\
\text { muito }\end{array}$ & Discordo & Concordo & $\begin{array}{r}\text { Concord } \\
\text { o muito }\end{array}$ \\
\hline Todas as pessoas têm que ter uma religião. & $24,3 \%$ & $40,5 \%$ & $29,7 \%$ & $5,4 \%$ \\
\hline Quem não acredita em Deus vai para o inferno. & $24,3 \%$ & $29,7 \%$ & $32,4 \%$ & $13,5 \%$ \\
\hline $\begin{array}{l}\text { Todos os evangélicos são fanáticos (radicais, } \\
\text { exagerados). }\end{array}$ & $45,9 \%$ & $35,1 \%$ & $16,2 \%$ & $2,7 \%$ \\
\hline O candomblé é uma religião do demônio. & $24,3 \%$ & $27,0 \%$ & $29,7 \%$ & $18,9 \%$ \\
\hline $\begin{array}{l}\text { Alunos do candomblé e da umbanda podem } \\
\text { usar suas guias (colares de santo) na escola. }\end{array}$ & $22,9 \%$ & $34,3 \%$ & $40,0 \%$ & $2,9 \%$ \\
\hline $\begin{array}{l}\text { Estudantes evangélicos podem fazer trabalhos } \\
\text { escolares sobre religiões africanas. }\end{array}$ & $14,3 \%$ & $25,7 \%$ & $57,1 \%$ & $2,9 \%$ \\
\hline É melhor acreditar na Bíblia do que na Ciência. & $10,8 \%$ & $37,8 \%$ & $18,9 \%$ & $32,4 \%$ \\
\hline $\begin{array}{l}\text { Quem acredita em imagens de santo não vai } \\
\text { para o céu. }\end{array}$ & $30,6 \%$ & $41,7 \%$ & $22,2 \%$ & $5,6 \%$ \\
\hline Só existe uma religião verdadeira. & $29,7 \%$ & $51,4 \%$ & $10,8 \%$ & $8,1 \%$ \\
\hline $\begin{array}{l}\text { É bom quando a professora reza na aula com } \\
\text { os alunos. }\end{array}$ & $22,2 \%$ & $33,3 \%$ & $36,1 \%$ & $8,3 \%$ \\
\hline
\end{tabular}

Tabela 4.5 - Respostas dos estudantes do colégio Água Viva ao questionário 2017

No contexto da escola Água Viva em 2017 podemos ver algumas mudanças em relação ao universo da pesquisa. Para a afirmação "todos tem que ter uma religião" a concordância é maior entre os estudantes da Água Viva (34\% contra 19\%). Na afirmação "quem não acredita em Deus vai para o inferno" a concordância é de $27 \%$ no universo, e de $55 \%$ no colégio Água Viva. Já na frase “o candomblé é uma religião do demônio" desse percentual é de $30 \%$ no universo e $48 \%$ na amostra. Ou seja, quase metade dos estudantes que responderam o questionário no colégio Água Viva acreditam que o candomblé é uma religião do 
demônio. Já se os alunos do candomblé podem usar suas guias na escola, a porcentagem de concordância no geral chega a quase $60 \%$. No Colégio Água Viva cai para $42 \%$.

O restante das afirmativas apresentadas não apresentou diferenças significantes de porcentagem entre o universo total e as respostas da escola Água Viva.

A comparação das porcentagens compõe mais um indício da importância do estudo mais aprofundado dessa escola.

\section{2.}

\section{Análise dos questionários 2018}

Nesta seção, analisamos as respostas dos estudantes do sétimo ano da escola Água Viva em 2018 para as dez questões relacionadas à religião presentes na primeira parte do questionário. Elas consistiam em afirmativas para as quais os estudantes deveriam expressar sua concordância por meio de uma escala de Likert de quatro pontos (discordo muito, discordo, concordo e concordo muito). Os percentuais de cada item podem ser observados na tabela 4.6.

\begin{tabular}{|l|r|r|r|r|}
\hline \multicolumn{1}{|c|}{ Afirmativas } & \multicolumn{1}{|c|}{$\begin{array}{c}\text { Discordo } \\
\text { muito }\end{array}$} & Discordo & Concordo & $\begin{array}{c}\text { Concordo } \\
\text { muito }\end{array}$ \\
\hline Todas as pessoas têm que ter uma religião. & $38,9 \%$ & $55,6 \%$ & $5,6 \%$ & $0,0 \%$ \\
\hline Quem não acredita em Deus vai para o inferno. & $33,3 \%$ & $47,2 \%$ & $13,9 \%$ & $5,6 \%$ \\
\hline $\begin{array}{l}\text { Todos os evangélicos são fanáticos (radicais, } \\
\text { exagerados). }\end{array}$ & $26,5 \%$ & $50,0 \%$ & $17,6 \%$ & $5,9 \%$ \\
\hline O candomblé é uma religião do demônio. & $25,0 \%$ & $55,6 \%$ & $13,9 \%$ & $5,6 \%$ \\
\hline $\begin{array}{l}\text { Estudantes evangélicos podem fazer trabalhos } \\
\text { escolares sobre religiões africanas. }\end{array}$ & $8,8 \%$ & $14,7 \%$ & $50,0 \%$ & $26,5 \%$ \\
\hline É melhor acreditar na Bíblia do que na Ciência. & $8,3 \%$ & $36,1 \%$ & $33,3 \%$ & $22,2 \%$ \\
\hline $\begin{array}{l}\text { Quem acredita em imagens de santo não vai } \\
\text { para o céu. }\end{array}$ & $22,2 \%$ & $58,3 \%$ & $13,9 \%$ & $5,6 \%$ \\
\hline Só existe uma religião verdadeira. & $27,8 \%$ & $61,1 \%$ & $5,6 \%$ & $5,6 \%$ \\
\hline $\begin{array}{l}\text { É bom quando a professora reza na aula com os } \\
\text { alunos. }\end{array}$ & $20,0 \%$ & $40,0 \%$ & $40,0 \%$ & $0,0 \%$ \\
\hline
\end{tabular}

Tabela 4.6 - Respostas dos estudantes do colégio Água Viva ao questionário 2018

A primeira afirmativa era "todas as pessoas têm que ter uma religião". Como pode ser visto na tabela 4.6. 38,9\% dos alunos discordam muito dessa afirmação; 55,6\% discordam e apenas 5,6\% concordam com a afirmação. Nenhum 
aluno respondeu que concorda muito com a afirmação. É possível notar um percentual de discordância de 94,5\% em relação a essa afirmação.

Esse dado torna-se compreensível se levarmos em consideração que $44 \%$ da turma, entre ateus e os que acreditam em Deus, não tem religião. No entanto, como podemos notar na tabela 4.7 , mesmo os alunos religiosos discordam dessa afirmação $^{16}$.

\begin{tabular}{|l|r|r|r|r|r|}
\hline \multirow{2}{*}{ Religião } & \multicolumn{5}{|c|}{ Todas as pessoas têm que ter uma religião } \\
\cline { 2 - 6 } & $\begin{array}{c}\text { Discordo } \\
\text { muito }\end{array}$ & Discordo & Concordo & $\begin{array}{c}\text { Concordo } \\
\text { muito }\end{array}$ & Total \\
\hline $\begin{array}{l}\text { Acredito em Deus, mas } \\
\text { não tenho religião }\end{array}$ & $46,7 \%(7)$ & $46, \%(7)$ & $6,7 \%(1)$ & 0 & $100 \%(15)$ \\
\hline Ateu & $100,0 \%(1)$ & 0 & 0 & 0 & $100 \%(1)$ \\
\hline Católico & $33,3 \%(3)$ & $66,7 \%(6)$ & 0 & 0 & $100 \%(9)$ \\
\hline Evangélico & $33,3 \%(3)$ & $66,7 \%(6)$ & 0 & 0 & $100 \%(9)$ \\
\hline Outro & 0 & $100 \%(1)$ & 0 & 0 & $100 \%(1)$ \\
\hline \multicolumn{1}{|c|}{ Total } & $40 \%(14)$ & $57,1 \%(20)$ & $2,9 \%(1)$ & 0 & $100 \%(35)$ \\
\hline
\end{tabular}

Tabela 4.7 - Respostas dos estudantes do $8^{\circ}$ ano da escola Água Viva em 2018 para a afirmativa "Todas as pessoas têm que ter uma religião", de acordo com seus grupos de religião.

A partir da tabela 4.7, é possível notar que os católicos e evangélicos, religiões presentes nas turmas estudadas, discordam da afirmação, em ambos os casos com um índice de $100 \%$. O curioso nesse caso é que um aluno que se declara como sem religião é o único a concordar com a afirmativa.

A segunda afirmativa dizia "quem não acredita em Deus vai para o Inferno". Como podemos notar na tabela 4.6, 33,3\% dos alunos discordam muito; 47,2\% discordam; $13,9 \%$ concordam e 5,6 \% concordam muito.

Se somarmos as porcentagens de discordo muito e discordo, podemos notar que $80,5 \%$ dos alunos discordam dessa afirmativa. Já 19,5\% dos alunos concordam com a afirmação. Na tabela 4.8 veremos a distribuição dessa resposta por religião.

\footnotetext{
${ }^{16}$ Quando cruzamos os dois dados, apenas uma pessoa é identificada como concordando com a afirmação. Isso se dá devido à segunda pessoa que afirmou concordar não ter indicado sua situação religiosa.
} 


\begin{tabular}{|l|r|r|r|r|r|}
\hline \multirow{2}{*}{ Religião } & \multicolumn{4}{|c|}{ Quem não acredita em Deus vai para o inferno } \\
\cline { 2 - 6 } & $\begin{array}{c}\text { Discordo } \\
\text { muito }\end{array}$ & \multicolumn{1}{|c|}{ Discordo } & Concordo & $\begin{array}{c}\text { Concordo } \\
\text { muito }\end{array}$ & Total \\
\hline $\begin{array}{l}\text { Acredito em Deus, mas } \\
\text { não tenho religião }\end{array}$ & $46,7 \%(7)$ & $40,0 \%(6)$ & $13,3 \%(2)$ & $0,0 \%(0)$ & $100,0 \%(15)$ \\
\hline Ateu & $100,0 \%(1)$ & $0,0 \%(0)$ & $0,0 \%(0)$ & $0,0 \%(0)$ & $100,0 \%(1)$ \\
\hline Católico & $22,2 \%(2)$ & $66,7 \%(6)$ & $11,1 \%(1)$ & $0,0 \%(0)$ & $100,0 \%(9)$ \\
\hline Evangélico & $22,2 \%(2)$ & $33,3 \%(3)$ & $22,2 \%(2)$ & $22,2 \%(2)$ & $100,0 \%(9)$ \\
\hline Outro & $0,0 \%(0)$ & $100,0 \%(0)$ & $0,0 \%(0)$ & $0,0 \%(0)$ & $100,0 \%(1)$ \\
\hline \multirow{2}{*}{ Total } & $34,3 \%(12)$ & $45,7 \%(16)$ & $14,3 \%(5)$ & $5,7 \%(2)$ & $100,0 \%(35)$ \\
\hline
\end{tabular}

Tabela 4.8 - Respostas dos estudantes do 8 ano da escola Água Viva, em 2018, para a afirmativa "Quem não acredita em Deus vai para o inferno", por religião, de acordo com seus grupos de religião.

Por essa tabela é possível ver que dos alunos que acreditam em Deus mas não tem religião, $86,7 \%$ discordam da afirmação, enquanto $13,3 \%$ concordam.

Já analisando os casos de católicos e evangélicos, é notável uma maior concordância entre os evangélicos em relação a afirmação do que nos católicos. Enquanto 44,4\% dos evangélicos concordam com a afirmação, apenas $11,1 \%$ dos católicos o faz. Como nos mostra Mariano (2003) as igrejas evangélicas, principalmente as pentecostais, têm um discurso muito forte de combate ao Diabo e ao inferno. É possível que essa questão, ao falar explicitamente de inferno, provavelmente chamou a atenção desses alunos.

A terceira afirmativa dizia "Todos os evangélicos são fanáticos (radicais, exagerados)". É importante explicar que a definição da palavra entre parênteses se fez necessária devidos às muitas dúvidas que o termo 'fanáticos' suscitou durante o pré-teste do questionário.

A tabela nos mostra que $25 \%$ dos alunos discordam muito da afirmação; 47,2 \% discordam; $16,7 \%$ concordam e 5,6\% concordam muito. Ou seja, 72,2\% dos respondentes discordam da afirmação, enquanto $27,8 \%$ concordam. Vejamos na tabela 4.9 a divisão por religião. 


\begin{tabular}{|l|r|r|r|r|r|}
\hline \multirow{2}{*}{ Religião } & \multicolumn{4}{|c|}{ Todos os evangélicos são fanáticos (radicais, exagerados) } \\
\cline { 2 - 6 } & \multicolumn{1}{|c|}{$\begin{array}{c}\text { Discordo } \\
\text { muito }\end{array}$} & Discordo & Concordo & \multicolumn{1}{c|}{$\begin{array}{c}\text { Concordo } \\
\text { muito }\end{array}$} & Total \\
\hline $\begin{array}{l}\text { Acredito em Deus, mas } \\
\text { não tenho religião }\end{array}$ & $15,4 \%(2)$ & $61,5 \%(8)$ & $15,4 \%(2)$ & $7,7 \%(1)$ & $100,0 \%(13)$ \\
\hline Ateu & $100,0 \%(1)$ & $0,0 \%(0)$ & $0,0 \%(0)$ & $0,0 \%(0)$ & $100,0 \%(1)$ \\
\hline Católico & $11,1 \%(1)$ & $44,4 \%(4)$ & $33,3 \%(3)$ & $11,1 \%(1)$ & $100,0 \%(9)$ \\
\hline Evangélico & $33,3 \%(3)$ & $55,6 \%(5)$ & $11,1 \%(1)$ & $0,0 \%(0)$ & $100,0 \%(9)$ \\
\hline Outro & $100,0 \%(1)$ & $0,0 \%(0)$ & $0,0 \%(0)$ & $0,0 \%(0)$ & $100,0 \%(1)$ \\
\hline \multicolumn{1}{c}{ Total } & $24,2 \%(8)$ & $51,5 \%(17)$ & $18,2 \%(6)$ & $6,1 \%(2)$ & $100,0 \%(33)$ \\
\hline
\end{tabular}

Tabela 4.9 - Respostas dos estudantes do 8 ano da escola Água Viva em 2018 para a afirmativa "Todos os evangélicos são fanáticos (radicais, exagerados)", de acordo com seus grupos de religião.

Por essa tabela podemos notar que, dos alunos que acreditam em Deus, mas não tem religião, $76,9 \%$ discordam da afirmação, enquanto $23,1 \%$ concordam. Entre os católicos, 55,5\% discordam da afirmação, enquanto 44,4\% concordam, uma divisão bem equilibrada. Já entre os próprios evangélicos, a quem a questão se referia, $88,9 \%$ discordam da afirmação, enquanto $11,1 \%$ concordam. Essa estatística indica que a visão dos evangélicos entre pessoas que não são evangélicas é diferente do que para os próprios evangélicos.

A quarta afirmação do questionário dizia "O Candomblé é uma religião do demônio". Os dados da tabela nos mostram que $25 \%$ dos alunos discordam muito da afirmação; $55,6 \%$ discordam; 5\% concordam e 5,6\% concordam muito.

Quando dividimos as respostas por religião, tabela 4.10, podemos ver que 93,3\% dos que acreditam em Deus, mas não tem religião discordam da afirmativa, enquanto $6,7 \%$ concordam. Dentre os católicos, $77,8 \%$ discordam, enquanto 22,2 $\%$ concordam. Já entre os evangélicos, $66,7 \%$ discordam, enquanto 33,3\% concordam com a afirmativa. É importante notar que que os evangélicos apresentam o menor percentual de discordância entre os grupos estudados. É possível que também seja reflexo de uma associação do candomblé ao demônio feita pelos evangélicos pentecostais. 


\begin{tabular}{|l|r|r|r|r|r|}
\hline \multirow{2}{*}{ Religião } & \multicolumn{5}{|c|}{ O candomblé é uma religião do demônio. } \\
\cline { 2 - 6 } & $\begin{array}{c}\text { Discordo } \\
\text { muito }\end{array}$ & \multicolumn{1}{c|}{ Discordo } & \multicolumn{1}{c|}{ Concordo } & \multicolumn{1}{c|}{$\begin{array}{c}\text { Concordo } \\
\text { muito }\end{array}$} & \multicolumn{1}{c|}{ Total } \\
\hline $\begin{array}{l}\text { Acredito em Deus, mas } \\
\text { não tenho religião }\end{array}$ & $40,0 \%(6)$ & $53,3 \%(8)$ & $0,0 \%(0)$ & $6,7 \%(1)$ & $100,0 \%(15)$ \\
\hline Ateu & $100,0 \%(1)$ & $0,0 \%(0)$ & $0,0 \%(0)$ & $0,0 \%(0)$ & $100,0 \%(1)$ \\
\hline Católico & $11,1 \%(1)$ & $66,7 \%(6)$ & $22,2 \%(2)$ & $0,0 \%(0)$ & $100,0 \%(9)$ \\
\hline Evangélico & $0,0 \%(0)$ & $66,7 \%(6)$ & $22,2 \%(2)$ & $11,1 \%(1)$ & $100,0 \%(9)$ \\
\hline Outro & $100,0 \%(1)$ & $0,0 \%(0)$ & $0,0 \%(0)$ & $0,0 \%(0)$ & $100,0 \%(1)$ \\
\hline & $25,7 \%(9)$ & $57,1 \%(20)$ & $11,4 \%(4)$ & $5,7 \%(2)$ & $100,0 \%(35)$ \\
\hline
\end{tabular}

Tabela 4.10 - Respostas dos estudantes do 8a ano da escola Água Viva em 2018 para a afirmativa "O Candomblé é uma religião do demônio" de acordo com seus grupos de religião.

A quinta afirmativa do questionário dizia que "alunos de candomblé e umbanda podem usar suas guias (colares de santos) na escola". Mais uma vez foi necessária a explicação do termo "guias" devido aos questionamentos que apareceram durante o pré-teste do questionário. Em relação a essa afirmação podemos notar que $16,7 \%$ dos alunos discordam muito, $27,8 \%$ discordam e 55,6\% concordam.

Quando dividimos essa questão por religião, como podemos ver na tabela 4.11, podemos notar que 43,3\% dos alunos que acreditam em Deus, mas não tem religião discordam dessa afirmação, enquanto 66,7\% concordam. Quantos aos católicos, 44,4\% discordam, enquanto 55,6\% concordam, um número bastante equilibrado. Em relação aos evangélicos 55,5\% discordam, enquanto 44,4\% concordam. É interessante notar a semelhança dos números entre católicos e protestantes. No entanto, os protestantes tendem mais a discordar e os católicos a concordar. Nenhum aluno marcou que concorda muito.

\begin{tabular}{|c|c|c|c|c|}
\hline \multirow[b]{2}{*}{ Religião } & \multicolumn{4}{|c|}{$\begin{array}{l}\text { Alunos do candomblé e da umbanda podem usar } \\
\text { suas guias (colares de santo) na escola }\end{array}$} \\
\hline & $\begin{array}{l}\text { Discordo } \\
\text { muito }\end{array}$ & Discordo & Concordo & Total \\
\hline $\begin{array}{l}\text { Acredito em Deus, mas não } \\
\text { tenho religião }\end{array}$ & $20,0 \%(3)$ & $13,3 \%(2)$ & $66,7 \%(10)$ & $100,0 \%(15)$ \\
\hline Ateu & $0,0 \%(0)$ & $0,0 \%(0)$ & $100,0 \%(1)$ & $100,0 \%(1)$ \\
\hline Católico & $0,0 \%(0)$ & $44,4 \%(4)$ & $55,6 \%(5)$ & $100,0 \%(9)$ \\
\hline Evangélico & $22,2 \%(2)$ & $33,3 \%(3)$ & $44,4 \%(4)$ & $100,0 \%(9)$ \\
\hline Outro & $0,0 \%(0)$ & $100,0 \%(1)$ & $0,0 \%(0)$ & $100,0 \%(1)$ \\
\hline Total & $14,3 \%(5)$ & $28,6 \%(10)$ & $57,1 \%(20)$ & $100,0 \%(35)$ \\
\hline
\end{tabular}

Tabela 4.11 - Respostas dos estudantes do 8 ano da escola Água Viva em 2018 para a afirmativa "Alunos de candomblé e umbanda podem usar suas guias (colares de santos) na escola", de acordo com seus grupos de religião. 
A sexta afirmativa do questionário dizia que "alunos evangélicos podem fazer trabalhos escolares sobre religiões africanas". Como podemos ver na tabela,4.6 8,3 \% dos alunos discordam muito dessa afirmação; 13,9 \% discordam, $47,2 \%$ concordam e $25 \%$ concordam muito.

Quando dividimos a afirmativa por religião, obtemos os dados da tabela 4.12, na qual podemos ver que, dos alunos que acreditam em Deus, mas não tem religião, 15,4 \% discordam dessa afirmação, enquanto 84,4\% concordam com ela. Dos alunos católicos, 22,2\% discordam da afirmação, enquanto 77,8\% concordam com ela. Entre os evangélicos, 44,4\% discordam da afirmação, enquanto 55,5\% concordam com ela.

É interessante notar como o grau de discordância da afirmação muda quando se trata dos evangélicos. Com as outras situações, um número próximo de $80 \%$ dos alunos concordam com a afirmação, enquanto entre os evangélicos o índice fica próximo de 50\%. Uma hipótese para essa diferença é que a questão os cita diretamente, assim como a questão sobre o fanatismo.

\begin{tabular}{|c|c|c|c|c|c|}
\hline \multirow[b]{2}{*}{ Religião } & \multicolumn{5}{|c|}{$\begin{array}{c}\text { Estudantes evangélicos podem fazer trabalhos escolares sobre } \\
\text { religiões africanas }\end{array}$} \\
\hline & $\begin{array}{l}\text { Discordo } \\
\text { muito }\end{array}$ & Discordo & Concordo & $\begin{array}{l}\text { Concordo } \\
\text { muito }\end{array}$ & Total \\
\hline $\begin{array}{l}\text { Acredito em Deus, mas } \\
\text { não tenho religião }\end{array}$ & $7,7 \%(1)$ & $7,7 \%(1)$ & $46,2 \%(6)$ & $38,5 \%(5)$ & $100,0 \%(13)$ \\
\hline Ateu & $0,0 \%(0)$ & $0,0 \%(0)$ & $100,0 \%(1)$ & $0,0 \%(0)$ & $100,0 \%(1)$ \\
\hline Católico & $0,0 \%(0)$ & $22,2 \%(2)$ & $66,7 \%(6)$ & $11,1 \%(1)$ & $100,0 \%(9)$ \\
\hline Evangélico & $22,2 \%(2)$ & $22,2 \%(2)$ & $33,3 \%(3)$ & $22,2 \%(2)$ & $100,0 \%(9)$ \\
\hline Outro & $0,0 \%(0)$ & $0,0 \%(0)$ & $0,0 \%(0)$ & $100,0 \%(1)$ & $100,0 \%(1)$ \\
\hline Total & $9,1 \%$ (3) & $15,2 \%(5)$ & $48,5 \%(16)$ & $27,3 \%(9)$ & $100,0 \%(33)$ \\
\hline
\end{tabular}

Tabela 4.12 - Respostas dos estudantes do 8o ano da escola Água Viva, em 2018, para a afirmativa "Alunos evangélicos podem fazer trabalhos escolares sobre religiões africanas", de acordo com seus grupos de religião.

A sétima afirmação do questionário era "é melhor acreditar na bíblia do que na ciência”. Essa questão não visava abordar a tolerância religiosa, mas a relação dos cristãos com o conhecimento científico. Como podemos ver na tabela 4.6, 8,3\% dos alunos discordam muito dessa afirmação; 36,1\% discordam, 33,3\% concordam e $22,2 \%$ concordam muito.

Vale a pena notar como o índice de concordância nessa questão é maior do que o de discordância. Como visto, excetuando-se os alunos que não tem religião, 
as religiões representadas são cristãs, sendo a bíblia sua referência central para o conhecimento doutrinário. Dessa maneira, tal resultado é, em certa medida, esperado.

Se observarmos as respostas por religiões, como podemos ver na tabela 4.13, é possível notar que, dos que acreditam em Deus, mas não tem religião, 53,3\% discordam da afirmação, enquanto 46,7\% concordam. Entre os católicos, $55,6 \%$ discordam, enquanto 44,4\% concordam. Já entre os evangélicos, 88,9\% concordam com a afirmativa, contra apenas $11,1 \%$ discordantes.

\begin{tabular}{|l|r|r|r|r|r|}
\hline \multirow{2}{*}{ Religião } & \multicolumn{5}{|c|}{ É melhor acreditar na Bíblia do que na Ciência } \\
\cline { 2 - 6 } & $\begin{array}{c}\text { Discordo } \\
\text { muito }\end{array}$ & Discordo & Concordo & $\begin{array}{c}\text { Concordo } \\
\text { muito }\end{array}$ & \multicolumn{1}{c|}{ Total } \\
\hline $\begin{array}{l}\text { Acredito em Deus, mas } \\
\text { não tenho religião }\end{array}$ & $13,3 \%(2)$ & $40,0 \%(6)$ & $26,7 \%(4)$ & $20,0 \%(3)$ & $100,0 \%(15)$ \\
\hline Ateu & $0,0 \%(0)$ & $100,0 \%(1)$ & $0,0 \%(0)$ & $0,0 \%(0)$ & $100,0 \%(1)$ \\
\hline Católico & $0,0 \%(0)$ & $55,6 \%(5)$ & $44,4 \%(4)$ & $0,0 \%(0)$ & $100,0 \%(9)$ \\
\hline Evangélico & $11,1 \%(1)$ & $0,0 \%(0)$ & $33,3 \%(3)$ & $55,6 \%(5)$ & $100,0 \%(9)$ \\
\hline Outro & $0,0 \%(0)$ & $0,0 \%(0)$ & $100,0 \%(1)$ & $0,0 \%(0)$ & $100,0 \%(1)$ \\
\hline & $8,6 \%(3)$ & $34,3 \%(12)$ & $34,3 \%(12)$ & $22,9 \%(8)$ & $100,0 \%(35)$ \\
\hline
\end{tabular}

Tabela 4.13 - Respostas dos estudantes do 8o ano da escola Água Viva em 2018 para a afirmativa "É melhor acreditar na bíblia do que na ciência", de acordo com seus grupos de religião.

Podemos notar, com isso, que os que acreditam em Deus, mas não tem religião, apresentam números semelhantes entre os que concordam e os que discordam. Percebe-se que, mesmo sem religião, a bíblia ainda é uma referência importante para esses alunos. É bastante expressivo também o grau de concordância dos evangélicos em relação aos católicos. Enquanto católicos apresentam praticamente um empate entre os que discordam e os que concordam, os evangélicos são quase unânimes ao concordarem que o conhecimento bíblico é mais válido do que o científico. Esses dados indicam uma relação diferente de católicos e evangélicos com a bíblia, em que os últimos lhe atribuem uma importância maior.

A oitava afirmação do questionário dizia que "quem acredita em imagens de santos não vai para o céu”. Os dados disponíveis na tabela 4.6 nos mostram que $22,2 \%$ dos alunos discordam muito da afirmativa; 58,3\% discordam; $13.9 \%$ concordam e $5,6 \%$ concordam muito.

Quando analisamos as respostas por religião, tabela 4.14, podemos notar que $73,4 \%$ dos que acreditam em Deus, mas não tem religião, discordam da 
afirmação, enquanto $26,6 \%$ concordam com ela. Entre os católicos, $100 \%$ discordam da afirmação. Esse dado era esperado, na medida que a religião católica é relacionada com a crença em santos e a existência de suas imagens. Já entre os evangélicos, $66,7 \%$ discordam da afirmação, enquanto $33,3 \%$ concordam com ela. Esse dado nos indica uma crença comum entre os evangélicos que as imagens de santos são pecaminosas. Segundo Mariano (2008, p.88)

"O Pentecostalismo brasileiro, seguindo pari passu o Protestantismo histórico, construiu sua identidade religiosa em radical oposição ao Catolicismo, seja o popular ou o oficial. Daí as severas críticas dos pentecostais de todos os quadrantes ao culto mariano (nomeado por eles de mariolatria), ao papado, à adoração de imagens e de santos e à reza do terço"

\begin{tabular}{|l|r|r|r|r|r|}
\hline \multirow{2}{*}{ Religião } & \multicolumn{4}{|c|}{ Quem acredita em imagens de santo não vai para o céu. } \\
\cline { 2 - 6 } & $\begin{array}{c}\text { Discordo } \\
\text { muito }\end{array}$ & \multicolumn{1}{|c|}{ Discordo } & Concordo & $\begin{array}{c}\text { Concordo } \\
\text { muito }\end{array}$ & \multicolumn{1}{c|}{ Total } \\
\hline $\begin{array}{l}\text { Acredito em Deus, mas } \\
\text { não tenho religião }\end{array}$ & $26,7 \%(4)$ & $46,7 \%(7)$ & $20,0 \%(3)$ & $6,7 \%(1)$ & $100,0 \%(15)$ \\
\hline Ateu & $100,0 \%(1)$ & $0,0 \%(0)$ & $0,0 \%(0)$ & $0,0 \%(0)$ & $100,0 \%(1)$ \\
\hline Católico & $22,2 \%(2)$ & $77,8 \%(7)$ & $0,0 \%(0)$ & $0,0 \%(0)$ & $100,0 \%(9)$ \\
\hline Evangélico & $11,1 \%(1)$ & $55,6 \%(5)$ & $22,2 \%(2)$ & $11,1 \%(1)$ & $100,0 \%(9)$ \\
\hline Outro & $0,0 \%(0)$ & $100,0 \%(1)$ & $0,0 \%(0)$ & $0,0 \%(0)$ & $100,0 \%(1)$ \\
\hline & $22,9 \%(8)$ & $57,1 \%(20)$ & $14,3 \%(5)$ & $5,7 \%(2)$ & $100,0 \%(35)$ \\
\hline
\end{tabular}

Tabela 4.14 - Respostas dos estudantes do 8a ano da escola Água Viva em 2018 para a afirmativa "Quem acredita em imagens de santos não vai para o céu, de acordo com seus grupos de religião.

A nona afirmação do questionário dizia que "só existe uma religião verdadeira", e os dados podem ser vistos na tabela 4.6. 27,8\% discordam muito da afirmação; $61,1 \%$ discordam, enquanto $5,6 \%$ concordam e 5,6\% concordam muito. Esses dados mostram uma forte discordância, de maneira geral, com a ideia de que só uma religião é verdadeira.

Quando exploramos os dados por religião, obtemos os dados da tabela 4.15. Nela podemos perceber que, dos que acreditam em Deus, mas não tem religião, 88,6\% discordam da afirmativa, enquanto 13,4\% concordam. Entre os católicos, 100\% discordam da afirmação. Já entre os evangélicos, há 22,2\% de concordância e $77,8 \%$ de discordância. 


\begin{tabular}{|l|r|r|r|r|r|}
\hline \multirow{2}{*}{ Religião } & \multicolumn{5}{|c|}{ Só existe uma religião verdadeira. } \\
\cline { 2 - 6 } & \multicolumn{1}{|c|}{$\begin{array}{c}\text { Discordo } \\
\text { muito }\end{array}$} & \multicolumn{1}{|c|}{ Discordo } & Concordo & $\begin{array}{c}\text { Concordo } \\
\text { muito }\end{array}$ & \multicolumn{1}{c|}{ Total } \\
\hline $\begin{array}{l}\text { Acredito em Deus, mas } \\
\text { não tenho religião }\end{array}$ & $33,3 \%(5)$ & $53,3 \%(8)$ & $6,7 \%(1)$ & $6,7 \%(1)$ & $100,0 \%(15)$ \\
\hline Ateu & $100,0 \%(1)$ & $0,0 \%(1)$ & $0,0 \%(1)$ & $0,0 \%(1)$ & $100,0 \%(1)$ \\
\hline Católico & $33,3 \%(3)$ & $66,7 \%(6)$ & $0,0 \%(0)$ & $0,0 \%(0)$ & $100,0 \%(9)$ \\
\hline Evangélico & $0,0 \%(0)$ & $77,8 \%(7)$ & $11,1 \%(1)$ & $11,1 \%(1)$ & $100,0 \%(9)$ \\
\hline Outro & $100,0 \%(1)$ & $0,0 \%(0)$ & $0,0 \%(0)$ & $0,0 \%(0)$ & $100,0 \%(1)$ \\
\hline \multicolumn{1}{c|}{ Total } & $28,6 \%(10)$ & $60,0 \%(21)$ & $5,7 \%(2)$ & $5,7 \%(2)$ & $100,0 \%(35)$ \\
\hline
\end{tabular}

Tabela 4.15 - Respostas dos estudantes do 8a ano da escola Água Viva em 2018 para a afirmativa "Só existe uma religião verdadeira" de acordo com seus grupos de religião.

A décima afirmativa do questionário dizia que "é bom quando a professora reza com a turma". Os dados da tabela 4.6 nos mostram que 19,4\% discordam muito; 38,9\% discordam; 38,9\% concordam.

Quando dividimos os dados por religião, como mostra a tabela 4.16, vemos que, entre os que acreditam em Deus, mas não tem religião, 57,1\% discordam, enquanto $42,9 \%$ concordam. Entre os católicos, 44,4\% discordam, enquanto 55,6\% concordam. Quanto aos evangélicos, 66,6\% discordam e 33,3\% concordam. Aqui é interessante analisar que esta é uma afirmativa que fala do cotidiano da escola. É possível indicar que os estudantes católicos se sentiriam mais à vontade com uma oração do que os demais.

\begin{tabular}{|l|r|r|r|r|r|}
\hline \multirow{2}{*}{ Religião } & \multicolumn{4}{|c|}{ É bom quando a professora reza na aula com os alunos } \\
\cline { 2 - 6 } & $\begin{array}{c}\text { Discordo } \\
\text { muito }\end{array}$ & \multicolumn{1}{|c|}{ Discordo } & Concordo & $\begin{array}{c}\text { Concordo } \\
\text { muito }\end{array}$ & \multicolumn{1}{c|}{ Total } \\
\hline $\begin{array}{l}\text { Acredito em Deus, mas } \\
\text { não tenho religião }\end{array}$ & $7,1 \%(1)$ & $50,0 \%(7)$ & $42,9 \%(6)$ & $0,0 \%(0)$ & $100 \%(14)$ \\
\hline Ateu & $0,0 \%(0)$ & $100,0 \%(1)$ & $0,0 \%(0)$ & $0,0 \%(0)$ & $100 \%(1)$ \\
\hline Católico & $22,2 \%(2)$ & $22,2 \%(2)$ & $55,6 \%(2)$ & $0,0 \%(0)$ & $100 \%(9)$ \\
\hline Evangélico & $33,3 \%(3)$ & $33,3 \%(3)$ & $33,3 \%(3)$ & $0,0 \%(0)$ & $100 \%(9)$ \\
\hline Outro & $0,0 \%(0)$ & $100,0 \%(1)$ & $0,0 \%(0)$ & $0,0 \%(0)$ & $100 \%(1)$ \\
\hline & $17,6 \%(6)$ & $41,2 \%(14)$ & $41,2 \%(14)$ & $0,0 \%(0)$ & $100 \%(34)$ \\
\hline
\end{tabular}

Tabela 4.16 - "É bom quando a professora reza na aula com os alunos", por religião.

A décima primeira pergunta referente à religião no questionário, perguntava "já sofreu preconceito na escola por causa de sua religião, ou por não ter religião?”. Como nos mostra a tabela 4.17, 83,3\% afirmam nunca terem sofrido 
preconceito por religião; $11,1 \%$ muitas vezes; $2,8 \%$ sempre e $2,8 \%$ muitas vezes. Ou seja, de um universo de 36 alunos, 6 afirmam já terem sofrido, pelo menos uma vez, preconceito por razões religiosas no contexto escolar.

\begin{tabular}{|l|r|r|}
\hline $\begin{array}{c}\text { Já sofreu preconceito na escola por causa de } \\
\text { sua religião, ou por não ter religião? }\end{array}$ & Frequência & \multicolumn{2}{|c|}{ Percentual } \\
\hline Nunca & 30 & 83,3 \\
\hline Poucas vezes & 4 & 11,1 \\
\hline Muitas vezes & 1 & 2,8 \\
\hline Sempre & 1 & 2,8 \\
\hline Total & 36 & 100,0 \\
\hline
\end{tabular}

Tabela 4.17 - Respostas dos estudantes do 8a ano da escola Água Viva em 2018 para a afirmativa "Já sofreu preconceito na escola por causa de sua religião, ou por não ter religião?" de acordo com seus grupos de religião.

Dividimos esses dados por religião, na tabela 4.18.

\begin{tabular}{|l|r|r|r|r|r|}
\hline \multirow{2}{*}{ Religião } & \multicolumn{4}{|c|}{ Já sofreu preconceito na escola por causa de sua religião ou } \\
por não ter religião?
\end{tabular}

Tabela 4.18 - Respostas dos estudantes do 8a ano da escola Água Viva em 2018 para a afirmativa "Já sofreu preconceito na escola por causa de sua religião ou por não ter religião?", de acordo com seus grupos de religião.

Por essa tabela, dos que acreditam em Deus, mas não tem religião, 13,3\% já sofreram alguma vez, 22,2\% dos católicos, 22,2\% dos evangélicos e nenhum ateu. A análise desses dados, no entanto, encontra limites, já que a pergunta não nos permite saber o que os estudantes compreendem por preconceito. Isto é, é possível que determinadas atitudes sejam percebidas como preconceito para alguns deles e para outros não. 


\section{3.}

\section{Algumas conclusões}

Em geral, as respostas dos alunos tendem a respostas mais tolerantes. Em todas as situações, há uma porcentagem maior de alunos que respondem de acordo com parâmetros mais tolerantes em relação às religiões.

No entanto, quando analisamos, as respostas por opção religiosa dos alunos, é possível obter alguns dados interessantes. $\mathrm{Na}$ afirmativa número 2, por exemplo, "quem não acredita em Deus vai para o inferno", temos um índice geral de discordância de 80,5\%. No entanto, entre os evangélicos, o índice de discordância diminui para 55,5\%. Na afirmativa número quatro, “o candomblé é uma religião do demônio", o mesmo acontece. Enquanto o índice geral de discordância é de $80,6 \%$, entre os evangélicos esse índice cai para 66\%. Na afirmativa número oito "quem acredita em imagens de santos não vai para o céu" a discordância geral é de $80,5 \%$, e entre os evangélicos cai para $66,6 \%$.

Essas situações nos indicam que alguns conceitos chaves na teologia evangélica afetam a aceitação de outras religiões por parte desses alunos. As perguntas citadas se referem a outras religiões, acompanhadas de conceitos como céu, inferno, demônio e santos.

Um outro indicador importante é em relação a aceitação das religiões africanas no ambiente escolar. Sobre esse tópico podemos citar duas afirmações presentes no questionário. A primeira afirmação, número cinco diz que "alunos de candomblé e umbanda podem usar suas guias na escola". Nessa afirmação o índice geral de concordância da afirmação é de 55,6\%. Os católicos mantêm esse índice. Já entre os evangélicos, a concordância cai para 44,5\%.

A sexta afirmação diz que "alunos evangélicos podem fazer trabalhos sobre religiões africanas”. Nessa questão, o índice geral de concordância foi de 77,8\%. Entre os evangélicos, no entanto, a concordância cai para 55,5\%. O maior índice de intolerância religiosa em relação a religiões de matriz africana por evangélicos pode ser encontrada em outras pesquisas, como De Oliveira (2013), Santos (2017) e Quintana (2013).

Por fim, outra questão que traz um índice interessante é a afirmativa número sete "é melhor acreditar na bíblia do que na ciência". Essa questão não falava sobre tolerância, ou intolerância, mas sobre a relação entre religião e 
conhecimento. No geral, 44,4\% dos alunos discordam da afirmação e 55,5\% concordam com ela, um índice, mesmo que bem equilibrado, que pende para a maior aceitação da ciência em relação a bíblia. Esse índice se repete em relação aos católicos. Já entre os evangélicos, o grau de concordância com a afirmação chega a $88,9 \%$. Ou seja, há um indício de que alunos evangélicos tem uma maior dificuldade de aceitar a ciência como fonte de conhecimento. Essa é uma conclusão que foi também percebida em pesquisas anteriores, como Teixeira e Andrade (2014) e Dorvillé e Teixeira (2015).

No próximo capítulo iremos fazer uma análise dos dados qualitativos dessa pesquisa, tanto da observação feita no ambiente escolar, como das entrevistas realizadas com alunos e professores. 


\section{5 Análise dos dados qualitativos da escola Água Viva}

No presente capítulo analisaremos os dados provenientes de observações e entrevistas realizadas com professores e alunos. Na primeira seção iremos descrever e analisar as observações feitas nas salas de aula. Na segunda, vamos abordar as entrevistas realizadas com direção, alunos e professores.

\section{1. Observações}

As observações em sala de aula foram realizadas entre os meses de março e agosto de 2018. Como dito anteriormente, foram realizadas observações nas aulas de história e ciências em duas turmas de oitavo ano diferentes. Na turma da manhã, 801, foram observadas apenas as aulas de história, devido à recusa da professora de ciências desse turno. Já na turma da tarde, 802, foram observadas as aulas de história e ciências.

Durante a observação fui bem recebido por alunos e professores. Os alunos não me estranharam em nenhum momento. Fui apresentado para as duas turmas por seus professores, em um primeiro momento como estudante da PUC e pediram para que eu explicasse para os alunos o que constituía o mestrado e uma pesquisa. Disse para os alunos que depois que terminamos a escola podemos fazer um curso superior e, posteriormente, uma pós-graduação, no meu caso um mestrado. Expliquei que o meu objetivo ali era entender melhor o que eles pensavam e como era as relações deles no espaço escolar.

Os professores participantes também foram solícitos e me receberam bem em suas salas de aulas. Da mesma maneira, os docentes que não participaram da pesquisa e que encontrava, por vezes, no pátio ou sala dos professores, também me receberam bem, demonstrando interesse no objeto da minha pesquisa. Constantemente me chamavam para ficar na sala dos professores. Com frequência, aceitei o convite, todavia, em outros momentos, preferi ficar no pátio e observar o comportamento dos alunos. 


\subsection{1.}

\section{As aulas de história da turma 801}

A turma da manhã tinha aproximadamente 25 alunos que frequentavam as aulas, ainda que na chamada constassem 30 alunos. No entanto, havia um grupo que variava quanto à frequência. Não eram sempre os mesmos alunos que faltavam. Contudo, sempre havia por volta de 5 alunos faltantes, variando entre eles.

A turma era disposta em quatro fileiras, com alunos sentados em duplas. Eles se sentavam com quem queriam, não havendo nenhuma pré-indicação por parte do professor, ou da escola, em relação aos locais que os alunos deveriam se sentar. Essa turma demorava para se sentar e concentrar na aula. O professor, após entrar em sala de aula, precisava de 5 a 10 minutos para conseguir iniciar efetivamente a sua aula. Apesar dessa agitação, a turma se mostrava um pouco apática em relação aos conteúdos.

Os métodos utilizados pelo professor P1, geralmente, consistiam de aulas expositivas sobre os assuntos abordados, com esquemas escritos no quadro, que os alunos deveriam copiar. Outro método utilizado pelo professor em suas aulas era a leitura pelos alunos, em silêncio, de trechos do livro didático. Após a leitura, o professor fazia perguntas sobre o assunto lido pelos alunos e relia em voz alta os trechos onde se encontravam as respostas daquelas perguntas. Segundo o professor, esse método ajudava aos alunos entenderem o assunto.

O professor seguia uma lógica de uma primeira abordagem do assunto, quando ele explicava brevemente o tema abordado e os alunos tinham os primeiros contatos com aquela matéria. Em seguida, eles liam sobre o assunto, para, por último responder às perguntas, a fim de fixar o conteúdo. Outra razão para realizar as leituras como estudo era que, segundo P1, o "nível” de leitura dos alunos era baixo. Dessa forma, ele buscava estimulá-los a ler mais.

Durante os meses de observações, os assuntos abordados em ambas as turmas foram iluminismo e revolução francesa. Tais temáticas abordam, mesmo que indiretamente, questões religiosas. Ambos foram momentos de mudança de pensamentos e ações no cenário europeu, em que convicções até então cristalizadas, começaram a ser questionadas. A religião como detentora do conhecimento, na figura da Igreja Católica, começa a sofrer abalos. 
A turma 801 não se mostrava muito interessada nas aulas de história. O professor explicava a matéria, mas a turma não fazia perguntas e pouco indagava sobre o assunto. Na aula do dia 19 de março, por exemplo, o professor deu uma aula expositiva sobre a revolução francesa. Nela, ele explicou os três estados nobreza, clero e povo -, no contexto pré-revolucionário e colocou a Igreja como detentora de riqueza e poderes políticos. Mostrou também que a Igreja não pagava impostos, o que a diferenciava do cidadão comum. Em nenhum momento foi gerada uma discussão sobre o assunto por parte dos alunos. Eles apenas escutaram em silêncio.

$\mathrm{Na}$ aula do dia 26 de março, o professor falou sobre o grêmio estudantil, como funcionava e que teriam eleições no fim do ano. Usando esse gancho, o professor explicou sobre a formalização dos direitos humanos também no contexto da revolução francesa. Usou como exemplo que antes era uma sociedade de privilégios, em que os membros da Igreja tinham preferência frente aos cidadãos comuns. Mais uma vez isso não gerou uma discussão que envolvesse a turma.

$\mathrm{Na}$ aula do dia 02 de abril o professor narrou como os Jacobinos acabaram com o dízimo da Igreja. Nesse momento alguns alunos indagaram se era o mesmo esquema de dízimo das igrejas atuais. P1 respondeu que a lógica dos dízimos era parecida com os dias atuais, na qual alguém doa dinheiro para a igreja, afim de receber de volta as bênçãos. O professor, no entanto, não diferenciou a Igreja Católica, da época, com as igrejas evangélicas que os alunos se referiam. Imagino que esse assunto específico tenha chamado atenção dos alunos pois porque o dízimo é algo mais próximo deles e, por envolver algo concreto, como dinheiro, seja mais palpável para os alunos.

No mês de abril, em sua primeira semana, houve um trabalho na escola que incluía a turma 801. Esse trabalho foi feito por uma mulher, moradora da comunidade do Cantagalo, que objetivava fazer uma espécie de conscientização em relação ao comportamento das crianças. A mulher que coordenava esse trabalho era ligada à um ginásio de esportes da comunidade e teve sua entrada autorizada pela direção da escola para desenvolver o projeto. Durante esse trabalho, pude perceber a religião atuando como forma disciplinadora no espaço escolar. A proponente do trabalho pediu aos alunos que fizessem uma redação sobre suas vidas. De posse dos textos dos estudantes, ela utilizou frases como 
"vocês querem ser traficantes? Ou trabalhadores?" "se estudarem, podem chegar a ser patrões" "você quer ser jogador de futebol? Não quer não, se não estudava. Vai ser bandido". Além dessas frases, tidas como motivacionais, era utilizada o tempo todo a expressão "glória a Deus". Os alunos foram convidados a escolher animais que os representasse. Os alunos que escolheram o peixe foram associados a Cristo, indicando que eles estavam no caminho correto.

Os alunos escutavam ela com muita atenção, em um forte silêncio. Observei que isso pareceu se dever mais à forma efusiva com que falava, do que devido ao conteúdo do que dizia. Vale ressaltar que esse trabalho não foi feito pelo professor ou pela escola, mas sim por uma pessoa externa que propõe essas "oficinas" em escolas em que o público de alunos mora massivamente em favelas.

No contexto da turma 801 a religião não me pareceu ser uma questão que mobilizasse a turma. Em nenhum momento nessa turma ouvi piadas ou comentários intolerantes nos temas religiosos abordados pelo professor.

\subsection{2.}

\section{As aulas de história da turma 802}

A turma 802, do turno da tarde, era menor do que a da manhã, contando com 22 alunos na chamada, porém, com frequência média de 15 alunos. Essa turma era menos agitada do que a turma da manhã e mais interessada nas aulas de história.

Um de seus alunos chamava muito a atenção na turma e também a minha como pesquisador. O aluno A1, que concedeu entrevista para essa pesquisa, se dizia uma mulher trans. Apesar de, segundo ela ${ }^{17}$, ainda não ter tido a oportunidade, por falta de dinheiro e pelo fato de não ser maior de idade, de fazer a transformação física, se considerava mulher.

Sua presença em sala de aula provocava diferentes reações. Em relação aos docentes observados, eles a tratavam com normalidade dentro da sala de aula. O professor P1 por vezes reclamava que a aluna gostava muito de chamar atenção e com frequência prejudicava o andamento de sua aula. Já em P2 senti um carinho mais pessoal pela aluna A1. Certa vez a professora chegou a presentear a aluna com um batom, pedindo para que não contasse que foi ela que o deu. Ouvi, no

\footnotetext{
${ }^{17}$ Irei me referir a esse aluno no gênero feminino pois, apesar de ter nascido e crescido como menino, hoje se reconhece como uma menina.
} 
entanto, em conversa na sala dos professores, que a aluna causava certo desconforto em alguns docentes. O professor de educação física disse não saber lidar com ela, pois ficava "mexendo com os meninos"; o professor de matemática disse que ela tinha direito de ser como quisesse. Já o professor de geografia disse que "até poderia ser viado, mas não precisava ficar mostrando".

A aluna se relacionava bem com a maioria de seus colegas. No entanto, era alvo de comentários irônicos e maldosos de outros, principalmente do sexo masculino, que debochavam de suas falas. A aluna respondia constantemente de forma agressiva, não fisicamente, mas verbalmente, consistindo em um mecanismo de defesa em um ambiente muitas vezes hostil.

$\mathrm{Na}$ aula do dia dois de abril, por exemplo, um aluno disse, aparentemente sem razão (já que nem A1 o havia provocado e nem a temática da aula tinha relação com sexualidade), que A1 deveria "virar homem", e que ela só era assim por não encontrar nenhuma mulher bonita para "pegar". Uma outra aluna afirmou que "tem que parar com essa palhaçada de homem achar que é mulher". A1 a ameaçou "enfiar a mão na cara dela". O professor ameaça retirar os alunos de sala e a discussão cessa. Essa situação ilustra a centralidade dessa aluna nas relações dessa turma. A turma se comportava de uma maneira quando ela estava presente e de outra quando estava ausente.

Segundo a professora P2 (Ciências), o preconceito com A1 por vezes partia de questões religiosas.

"Já, já ouvi, já ouvi assim um... mas já ouvi sim perguntarem pra ele ${ }^{18}$ se ele faria pacto com o Diabo pra conseguir o que ele quer, se ele queria ser mulher... qual é a religião dele, muitos já perguntaram pra ele com relação à isso. Eu acho que ele também fica com o pé assim meio atrás com as religiões que acham errado ele querer mudar de sexo."

Durante as aulas, essa aluna fazia questão de participar das indagações feitas pelo professor, o que fazia com que os outros alunos também participassem constantemente, já que acabava gerando perguntas que o professor repassava para o restante da turma.

Mais uma vez reitero a centralidade da presença de A1 na referida sala de aula. Como dito, alguns professores, não os diretamente observados, apresentaram falas preconceituosas em relação à aluna, mostrando um ambiente intolerante para

\footnotetext{
${ }^{18}$ Optamos por manter a forma como os entrevistados se expressaram, ainda que seja distinta do que argumentamos anteriormente.
} 
com ela. Os colegas de turma, como já exposto, demonstraram uma postura muitas vezes preconceituosa. Nas minhas observações notei duas motivações para esse comportamento dos colegas de turma. A primeira dessas motivações, principalmente por parte dos meninos, é achar que a aluna é homossexual por não ter experimentado ou não conseguir fazer o que se espera de um homem na sociedade. No entanto, também é possível notar uma motivação religiosa para esse comportamento, como evidenciado na fala de P2 abordada a cima. Em relação às atitudes dos professores, eles não lidam diretamente com esses conflitos e disputas em sala de aula. O que acontecia era uma ameaça de retirar da sala pela "confusão" criada, mas não uma conversa sobre respeito e preconceito, por exemplo.

Os assuntos abordados e os métodos utilizados pelo professor de história foram os mesmos já descritos acima. No entanto, a reação da turma se mostrou diferente da anterior. Na aula do dia 12 de março, sobre iluminismo, por exemplo, o professor citou o contexto da guerra da Síria e a aluna A1 indagou "por que os bofes, terroristas, querem acabar com a Síria", o professor perguntou "quem são os terroristas?" "os muçulmanos". Essa fala mostrou uma associação direta entre muçulmanos e terroristas feita pela aluna. O professor explicou que a motivação da guerra da Síria era econômica, e que a questão religiosa era apenas uma "cortina de fumaça" para aquela situação. Não foi explorada, nesse caso, a questão da tolerância.

$\mathrm{Na}$ aula do dia 13 de março, também sobre iluminismo, um outro aluno perguntou se havia perseguição por parte da Igreja aos iluministas. O professor esclareceu ao aluno que a Igreja dessa época não era protestante, mas sim católica. É possível perceber que muitos alunos, ao ouvirem o termo "igreja" associam diretamente às igrejas evangélicas, de forma natural, pois estão mais acostumados com essa presença religiosa.

$\mathrm{Na}$ aula do dia dezenove de março, sobre revolução francesa, o professor diz que o rei era uma espécie de Deus na terra. Os alunos se surpreendem com essa declaração pois não concebem a ideia de alguém se declarar um Deus. Um aluno chega a exclamar que "só existe um Deus". O professor pareceu não ouvir essa declaração. A1 pergunta se já existia o dízimo e diz que a igreja evangélica pede dinheiro para "fazer o salário dos irmãos". O professor responde que já existia o dízimo. No entanto, não faz comentários sobre "fazer o salário dos irmãos" 
Um outro aluno pergunta se a igreja ainda tem poder como na Idade Média. O professor responde que ainda tem poder político, mas não como na época. Ele cita a atuação política da bancada evangélica. Mas também ressalta que a religião tem o poder psicológico sobre as pessoas, pois se coloca como "representante de Deus na Terra”. O professor, nesse caso não diferencia as diferentes igrejas e religiões. Uma aluna retruca "glória a Deus", aparentemente sem ironias. O professor não reagiu a esse comentário.

De uma forma geral, apesar de ser uma turma mais ativa do que a 801 , o tema religião também não mobilizou grandes discussões na turma, para além das já citadas. Havia um interesse sobre o funcionamento, principalmente das igrejas evangélicas. É interessante notar que para alguns alunos, a ligação com as suas igrejas é um aspecto importante de sua vida e uma experiência que os fazem pensar sobre os conteúdos de história. Esse poderia ser um "gancho" em que ensino de história poderia contribuir para a discussão da tolerância religiosa. $\mathrm{O}$ momento da Reforma e da contrareforma, assim como o questionamento à autoridade religiosa são temas que interessam aos alunos e que o professor pode usar para mostrar que religiões e crenças presentes hoje no Brasil já foram perseguidas e questionadas em outros momentos. O professor de história, em minhas observações, não usou esses momentos com esse intuito. Mesmo no caso da síria, citado anteriormente, o professor não questiona se os muçulmanos seriam terroristas ou se todo muçulmano é terrorista, por exemplo.

Apesar desse ambiente com preconceito em relação à orientação sexual e gênero da aluna citada, em relação à religião não foram ouvidos comentários preconceituosos ou intolerantes. Mesmo os "argumentos" mobilizados para atacar a aluna A1 não eram religiosos, pelo menos durante a observação. Entretanto, nas entrevistas, que discutiremos mais adiante, fica claro que a religião também impulsionava a hostilidade em relação ao comportamento de A1.

\subsection{3.}

\section{As aulas de ciências da turma 802}

As aulas de ciências tinham uma estrutura um pouco diferente das de história. A professora utilizava muito a prática de desenho com seus alunos. Todo ano a Prefeitura do Rio fornece um caderno de desenho para a disciplina de artes. 
No entanto, como a modalidade de artes oferecida para esses alunos no ano de 2018 era a de música, os cadernos ficaram disponíveis para as aulas de ciências.

Além das aulas expositivas, portanto, a professora utilizava esse caderno para desenhar partes do corpo humano, que era o conteúdo programático desenvolvido ao longo de todo o ano letivo. Além disso, também era bastante utilizada a apostila fornecida pela prefeitura, tanto para atividades em sala, quanto para deveres de casa. Pedi para a professora para examinar a apostila. Não localizei, no entanto, nenhuma abordagem que poderia gerar uma polêmica envolvendo religião.

Em nenhum momento nas aulas de ciências foram mencionados assuntos religiosos. Mesmo quando a professora deu aula sobre sistema reprodutor, e os alunos fizeram algumas piadas de cunho sexual, isso não foi relacionado com valores religiosos nem pelos alunos e nem pela professora. Nesse momento não houve piadas em relação à sexualidade de A1. Os alunos estavam mais interessados em tirar suas próprias dúvidas a respeito da sexualidade. Uma aluna perguntou, por exemplo, se era possível engravidar com sexo oral. A professora respondeu que não, mas quepoderia transmitir doenças. As duas aulas que presenciei de educação sexual os alunos se interessavam para tirar dúvidas. No entanto, não foram abordados as diversidades sexuais e de gênero, apenas o aspecto biológico da reprodução.

\section{2.}

\section{Análise das entrevistas}

Nessa seção serão analisadas as entrevistas realizadas com professores, direção e alunos. As entrevistas tinham como objetivo ter uma melhor ideia do ambiente escolar e do trabalho realizado na escola, assim como aprofundar as concepções dos alunos, já inicialmente exploradas nos questionários. Foram entrevistados 3 professores, 1 diretora, e, 5 alunos. Seus perfis podem ser observados nos apêndices 5 e 6 . Uma vez que o objetivo principal dessa pesquisa era investigar se há casos de intolerância religiosa e se a escola poderia atuar para promover a tolerância entre pessoas de diferentes religiões, buscamos captar visões não só sobre a diversidade religiosa, mas também sobre o cotidiano escolar. 


\subsection{1. Entrevistas com professores e direção}

As entrevistas com professores e com a direção da escola tiveram como objetivo principal traçar impressões desses agentes escolares do ambiente escolar, das relações nesse ambiente e de como a religião se encontra no espaço escolar. Inicialmente, exploramos suas concepções sobre o cotidiano escolar e suas relações. Posteriormente, discutimos a presença da religião na escola. As entrevistas com esses profissionais ocorreram na própria escola, em salas em que estavam apenas o pesquisador e o(a) entrevistado(a), com duração média de 40 minutos

Em relação ao ambiente da escola da pesquisa, P1 disse que, quando foi trabalhar lá, em 2005, a escola tinha o apelido de "Carandiru", devido a seus altos índices de violência. No entanto, o professor afirmou que com o tempo essa realidade foi melhorando, se tornando uma escola de referência na região, onde os alunos pedem para estudar e professores pedem para ser transferido para lá. No entanto, não apontou as razões para essa melhora.

Já P2, que estava desde 2013 nessa escola, relata a mesma situação que o professor P1. Diz que antes era uma escola violenta e desorganizada, mas que foi se organizando com o tempo. P2 diz que atualmente gosta muito do ambiente escolar. A professora atribui essa transformação à mudança da equipe pedagógica em 2015, quando a atual diretora assumiu o cargo. Em sua visão, a atual equipe pedagógica "chega junto" dos alunos, não permitindo que as antigas atitudes de violência se perpetuem naquele ambiente.

Ainda em relação ao ambiente escolar, P3, que estava há apenas seis meses na escola, diz ser um bom ambiente, sem nenhuma reclamação.

A atual diretora da escola deu aula na escola entre 2011 e 2015. Ela relata:

"a gestora que aqui foi colocada em 2014 criou um clima muito ruim entre professores primário e ginásio e pessoal de apoio, como merendeiras, como faxineira com os professores. A gente era proibido de falar com eles, era uma coisa assim surreal, surreal... tanto que em agosto de 2014, essa gestora foi exonerada do cargo, né?! por... até por pedidos, pedidos não, imposição dos alunos, os alunos mesmo. Até um pessoal do ginásio, os alunos do ginásio, tiveram um problema sério aqui na escola e aí ela foi exonerada, mas hoje eu posso te dizer que a relação tanto aluno com professor é muito mais respeitosa, a gente graças a Deus conseguiu isso e entre professores entre si é maravilhosa, e eu considero a minha gestão como assim um marco muito bem definido, um antes e depois, hoje eu não tenho subordinados, eu tenho colegas de trabalho que contribuem muito comigo a ponto que no ano passado, eu fiquei de agosto a dezembro do ano passado sozinha 
na direção, não tinha adjunta, não tinha coordenadora, não tinha sala de leitura e não tinha secretária, e a gente conseguiu manter o nível da escola muito bom, respeito muito bom, e eu só consegui isso por causa da minha equipe de professores."

É importante também relatar que essa má relação da gestão anterior com alunos e professores foi atribuída pela atual direção ao seu intenso fanatismo religioso. Segundo a diretora, a antiga direção colocava todas as situações "nas mãos de Deus". Por exemplo, quando houve uma falta de água na escola e a direção não agiu sob o argumento que Deus proveria a água novamente. Também foi relatado que a escola tinha muitos dizeres religiosos na época espalhados pelo pátio e na sala da direção, o que já não acontecia mais durante o período de observação. Essas atitudes foram gerando um desgaste na relação com professores, e principalmente alunos, que debochavam intensamente da situação.

Todos os relatos aqui apresentados mostram que a escola, até 2015, tinha uma realidade de violência constante, que foi melhorando com a mudança de gestão. Os professores apontam que a nova gestão organizou melhor fisicamente o espaço escolar. A direção alega que os alunos passaram a ir com mais vontade de estudar para a escola.

No que concerne às interações entre os atores do espaço escolar, P1 diz que o relacionamento entre os alunos é bom e também entre estudantes e professores. Diz que acompanha, tanto a 801 , quanto a 802 , desde o $6^{\circ}$ ano, em 2016. Avalia que são turmas tranquilas quanto ao relacionamento. Ao dizer isso o professor se refere à ausência de conflitos diários entre os alunos, ausência de conflitos físicos em sala de aula.

P2, que dá aula para a 802, diz que existem agressões verbais, e que é uma turma bastante agitada. No entanto, fala que esses xingamentos não se convertem em agressões físicas.

"É, eles... mais ou menos né, eles às vezes eles assim... são meio agressivos um com outro, principalmente na... verbalmente, não chegam a ser agressivos assim de agressão física, mas eles gostam assim de fazer muita brincadeira assim de mau gosto, mas é característico também do adolescente, não é nada...não vejo nada assim muito fora do... da normalidade com eles não, tá?"

A professora avalia que a agressividade verbal é normal entre os adolescentes. Durante as observações de suas aulas, reparei que a professora agia com diálogo sempre que haviam ofensas em sala de aula, principalmente em 
relação a A1. P2 procurava parar a sua aula e dialogar sobre o problema que havia acontecido.

Já P3, que dá aulas para a turma 801, relata que a relação entre os alunos é boa. No entanto, diz que eles são preguiçosos, não gostam de "pegar no pesado" e pedem tempo livre o tempo todo. A professora diz que, academicamente, apenas duas meninas se destacam na turma.

Já a diretora, ao contrário do que dizem os professores, relata que o relacionamento entre as crianças não é tão bom quanto parece nas turmas de $8^{\circ}$ ano. Ela diz que

\begin{abstract}
"E, é uma batalha diária, né?! Pra gente conseguir que eles se relacionem bem, eles confundem muito a escola com o quintal de casa, eles trazem o problema de casa pra ser resolvido dentro da escola, ficam brigando lá e trazem a briga pra cá e a gente aqui que tem que tentar resolver. Muitas vezes a gente tem o apoio da família e a família presente, mas infelizmente isso não é uma totalidade, a família ainda é um pouco ausente tipo... "eu tô trabalhando e não posso ir" e "esse menino só me dá trabalho, eu não sei mais o que faço com ele", a gente ainda escuta muito isso. E o que a gente sente muita falta é do apoio da área de saúde, que muitos problemas poderiam ser resolvidos com um bom psicólogo, com uma boa conversa, e, infelizmente a gente não tem esse apoio."
\end{abstract}

É possível notar diferentes visões. P1 é quem acha as turmas mais tranquilas. P2 e a diretora já percebem mais os conflitos. P3 prioriza a disposição para o "trabalho" e o desempenho dos alunos para fazer sua avaliação da turma. Isso parece indicar que os professores têm diferentes envolvimentos com suas turmas. A diretora, que parece ter um contato mais próximo com os alunos e suas famílias, demonstra uma visão mais aprofundada, a qual aponta num sentido de conflitos e demandas nem sempre perceptíveis à primeira vista.

Outro ponto interessante da fala dela é essa noção de que os alunos trazem as brigas para escola e que as famílias poderiam ter papel mais ativo. Ou seja, ela reconhece que a escola não tem como dar conta dos conflitos e questões que os alunos trazem. Também ocorre, por outro lado, a mesma queixa recorrente de que a escola precisa de mais estrutura, de pessoal e de pouca participação por parte de algumas famílias.

\title{
5.2.1.1.
}

\section{A escola e a religião}

Após um panorama geral sobre o ambiente e suas relações, veremos agora o que os entrevistados disseram sobre a presença da religião na escola. Quando 
perguntados se a escola havia realizado algum projeto que tratasse sobre diversidade religiosa, todos os entrevistados disseram que nunca houve nenhum projeto voltado especificamente à diversidade religiosa na escola.

Em relação à presença da discussão sobre diversidade religiosa no currículo, P1, de história disse que em muitos momentos do currículo de história é trabalhada a questão da diversidade.

"Esse momento agora, por exemplo, você trabalha a questão do iluminismo. Quando você trabalha questões como direito de escolha, como direito do cidadão, isso também é um direito, inclusive escolha religiosa. Você trabalha a questão da laicidade do Estado, mas sem impedir que você tenha a sua escolha individual que é a questão do individualismo e também com o liberalismo, que é tradição liberal diga-se de passagem. Está sendo trabalhada o tempo todo no currículo."

Em relação à religião, o professor argumenta que vários conteúdos de história falam sobre a questão. Cita como exemplo a reforma protestante e o islamismo, conteúdos de $7^{\circ}$ ano. Dessa forma, avalia não ser necessário um trabalho extra sobre a questão, visto que o assunto já é contemplado no currículo da disciplina. O professor diz que, no ensino fundamental, a religião dos alunos nunca interferiu nos conteúdos dados em sala de aula. Ao contrário do ensino médio, onde o assunto de surgimento do ser humano gera uma discussão com os evangélicos, no fundamental isso não acontece. No entanto, isso pode indicar também a não exploração do assunto nas aulas de história,

O professor avalia que a religião deve entrar na aula de história como pano de fundo para fatos históricos, e não como uma discussão em si, já que a religião é uma opção pessoal. Há aqui, em certo sentido, uma ideia de que religião não se discute.

Para P2, muitos assuntos da disciplina de ciências também contemplam a diversidade. A professora diz que a discussão de gênero é muito ativa no conteúdo de ciências, na parte de corpo humano. Na minha observação, no entanto, não houve ocorrências dessa discussão durante a aula de sistema reprodutor.

A professora diz que alguns conteúdos geram uma discussão religiosa em sala, principalmente quando se fala de evolução. P2 relata que muitos alunos evangélicos entram em conflito quando é a aula desse conteúdo pois, segundo a professora, avaliam as duas correntes (criacionismo e evolucionismo) como dois polos opostos. Para a professora, que também é evangélica, é possível juntar as duas correntes, já que “o tempo de Deus não é o mesmo do homem”. 
A professora conta que alunos já relataram a demolição de terreiros no morro dos Tabajaras, por traficantes locais. A professora disse que os estudantes, mesmo os evangélicos, avaliaram essa atitude de forma negativa. No entanto, a professora também diz que a religião é uma escolha pessoal, que procura não influenciar nessas concepções.

\begin{abstract}
"Assim, se eles... mas assim é... a gente procura fazer de tudo para não influenciar o aluno com relação a isso. Acho que a religião é uma coisa muito pessoal, né? Normalmente a gente é influenciada primeiro pelos nossos pais, e depois a gente faz nossas escolhas. É... mas que o pai leve você desde de pequenininho, como eu já falei com você, eu sempre fui desde pequena, mas eu só fiz minha opção depois que eu fiquei mais velha, quando eu tinha...tinha noção do que era aquilo. Poderia ter feito uma opção diferente, de não ter continuado, né? Agora... eu procuro máximo não interferir nessa parte deles não."
\end{abstract}

É possível notar que, para P2 há uma associação entre falar de religião com os alunos com uma possível tentativa de conversão. Além disso, ressalta a importância da família para a construção das crenças religiosas, bem como seu caráter pessoal. Assim, percebe-se uma ideia de que a escola deveria discutir o mínimo possível assuntos relacionados à religião.

Para a professora P3 a religião não deve ser discutida na escola, pois gera polêmica. A professora, que foi criada como católica, mas se diz sem religião, alega que polêmicas, como discussões de gênero e religião, são colocadas na escola através da mídia, e que isso prejudica o trabalho da escola.

"Existe uma teoria da comunicação que é exatamente isso, eu implanto sementes do que as pessoas devem falar e uma das coisas é isso. A questão do gênero masculino, feminino e homossexual, tá? Tudo isso é implantado pela mídia. Nós somos extremamente marionetes e eu acho um absurdo isso também de ficar questionando religiosidade, porque isso aí é da mídia, tá? Eu não me sujeito as ideologias da mídia, tá?[...] Essas ideologias aí... de... que estão na mídia, não concordo com esse tipo de coisa. É... a minha formação é católica, preservo a família, preservo a honestidade, tem uma série de valores que tem que ser preservados, tá? Não é nem a mídia e nem a ideologia que vão fazer a minha cabeça. Não me sujeito a esse tipo de coisa. Não participo de nenhum grupo político, nem religioso, nem nada, não me prendo à nada,tá?"

Nessa fala de P3 podemos notar que a professora confunde as noções de gênero e sexualidade, igualando masculino, feminino e homossexual como diferentes opções de uma mesma categoria. Apesar de não mencionar o termo "ideologia de gênero", a professora considera que essa discussão é imposta na escola por ideologias de fora e que isso não deve ser discutido no ambiente 
escolar. É interessante notar também que, apesar de não se dizer pertencente a nenhum grupo, é conservadora em relação a valores que podem ser identificados com sua formação católica.

É possível notar que, para os três professores, a religião e a diversidade religiosa não são questões que tenham tanta importância em suas aulas. Para P1 e P2 o próprio conteúdo já dá conta do necessário. Já P3 pensa que esses assuntos não deveriam estar na escola.

É possível notar que P1 e P2 demonstram receios para falar de religião, por considerarem a questão de foro íntimo e fora da influência da escola. Já P3 tem uma postura bastante conservadora e também acha que o assunto não deve ser tratado na escola. A religião, para esses professores é um tema controverso fechado (HESS, 2009). Ou seja, percebem que é controverso e não querem abri-lo na escola. Ao não abrirem esses temas no ambiente escolar, os professores, em minha avaliação, não contribuem para uma discussão sobre tolerância religiosa no ambiente escolar.

Em relação ao preconceito religioso no contexto escolar, o professor P1 disse nunca ter presenciado nenhuma situação desse tipo, mas que há um deboche constante com as religiões de matriz africana. O professor diz que essas "ideias sobre as religiões africanas" vêm de fora, que os alunos trazem para dentro da escola. Ele afirma que logo interrompe as brincadeiras, para que "elas não se tornem preconceitos". No entanto, ele não classificou esse "deboche" como preconceito.

P2 também diz que nunca presenciou preconceitos religiosos em sua sala de aula. No entanto, afirma serem constantes comentários de "brincadeira" sobre religiões. Segundo a professora, os casos mais comuns dessas brincadeiras são com a Igreja Universal e com as religiões que ela chama de "espíritas".

"Eu noto que, assim, quando eles querem criticar bastante a igreja evangélica em si, eles vão pra igreja universal, até mesmo os próprios evangélicos que são de outras denominações, né? E...eles gostam de ficar zoando também às vezes quem também é espírita. Então às vezes aquele que pega santo, alguma coisa assim, eles zoam sim"

A professora P3 disse nunca ter presenciado nada disso. Essa professora evitou o tempo todo durante a entrevista fazer comentários mais profundos acerca da temática abordada. É possível que essa postura evasiva seja um indicativo de 
que não dá tanta importância para casos de intolerância religiosa (a ponto de achar que não são manifestações de preconceito).

Já a diretora adjunta disse "presenciar alguns bate-bocas" entre evangélicos e praticantes de religiões africanas. No entanto, não soube especificar um exemplo e não classificou a prática como "preconceito", mas como uma relação normal entre adolescentes.

Podemos notar, com esses relatos, que existem conflitos e tensões religiosas no ambiente escolar. No entanto, são interpretados como comportamentos de adolescentes. Segundo professores e direção, eles se preocupam sim e dialogam com os alunos sobre suas falas, mas não é uma preocupação central. A problemática da intolerância religiosa não é identificada por esses atores como um grande problema no ambiente escolar.

É interessante também notar que os três, P1, P2 e direção disseram que essas brincadeiras incluem mais constantemente alunos de religiões de matriz africana. P2 incluiu alunos da Igreja Universal como alvo das brincadeiras. Essa fala de P2 chama atenção de que os evangélicos, mesmo que muitas vezes apontados como autores de práticas intolerantes, também podem sofrer preconceitos no ambiente escolar.

Quando indagados se a religiosidade influenciava na sua conduta profissional, P1 disse que sua criação religiosa o ensinou valores de tolerância e respeito, e que usava isso em sala de aula. P2 e P3, por sua vez, dizem que não tem influência nenhuma. Já a diretora alega que tudo que aprendeu na vida, todos os valores, inclusive os religiosos, influenciam no seu trabalho.

Podemos comparar essas falas com o trabalho de Valente (2015). A autora mostra que a religiosidade está, principalmente, em atos e falas das próprias professoras observadas, mesmo que não sejam encontrada a existência do ensino religioso ou símbolos religiosos na decoração dos espaços escolares estudados por ela. Assim, é possível afirmar que a religiosidade está presente no espaço escolar, sendo trazida para dentro dos muros da escola por meio de seus agentes que carregam a dimensão da religiosidade em sua identidade. Em outras palavras, os professores seriam agentes sociais que acentuam a interdependência entre as agências por circularem tanto na instituição religiosa quanto na escolar. 
Por fim, perguntamos se eles consideravam a escola que trabalhavam como laica. Com essa pergunta objetivamos saber tanto a concepção de laicidade desses atores escolares, como se classificam a escola como laica.

P1 considera que laicidade é o Estado ser separado da religião e que o papel daquele é ser neutro em relação a esta.

\begin{abstract}
“A função do Estado, ele é arbitrar as coisas, então ele tem que ficar neutro e com isso dar educação, pregar uma tolerância não só religiosa, em todos os níveis, política, religiosa, cultural, entendeu?! Senão você vai ter lá um determinismo cultural, pregar uma superioridade de uma cultura sob a outra coisa que não existe, entendeu?! É função da educação é essa, mostrar que a tolerância em todos os aspectos, política, religiosa, cultural"
\end{abstract}

O professor considera a escola Água Viva como laica, pois, segundo ele, não há nenhuma influência de valores religiosos na condução do cotidiano da escola.

Para P2 a escola é laica porque

\begin{abstract}
"Porque a escola assim dá liberdade. Tanto dos profissionais como dos alunos de opinarem escolherem a religião que quiser. Sem impor nada! Pelo menos a vivência que eu tenho com os professores, a gente procura sempre respeitar a opinião dos alunos e deixar ele decida por si só. Eu não gosto nem de falar da minha pra depois não influenciar eles e falar 'ah, eu gosto da professora', ela é assim e vou ser isso. Porque mal ou bem os artistas podem influenciar pelas atitudes e os professores também pode, positivamente ou negativamente, né? Se eles têm algum tipo de admiração por você, às vezes você pode influenciar eles. Então eu evito até falar. Eu tenho uma aluna do nono ano que ela é muito agarrada comigo, ela não tem mãe e tal. E ela começou a frequentar uma igreja aí, há pouco tempo que falei pra ela que eu era evangélica também e ela não sabia. Ela convive comigo há 3 anos e ela não sabia. Ela me contava as coisas dela, eu ouvia e tal, não dava opinião e não falava. Até pra não influenciar pra depois não falar. Aí ela ficou até chocada quando eu falei pra ela que eu sempre fui da igreja desde nova. E aí ela falou assim que porque eu nunca tinha falado, aí eu falei ah, porque achava que não tinha nada a ver,né, não quero influenciar eles assim nesse sentido. Eu falo isso pra você não só no sentido religioso, mas também em outros ponto de vista que eu possa ter no meu pessoal, seja diferente do deles.
\end{abstract}

Para a professora, portanto, laicidade tem a ver com liberdade de crença, onde a escola tem o dever de não influenciar na conduta do aluno. A laicidade, para essa professora, isola a discussão sobre a religião do espaço escolar. $\mathrm{Na}$ busca pela neutralidade, a religião não é discutida.

Para P3 a escola deve exercer sua laicidade dando liberdade de expressão para os alunos. A professora sugere que tenha uma seção dentro da disciplina de filosofia para discutir as "grandes religiões". Segundo ela, 
"Mas se tivesse uma disciplina dentro da área de filosofia, pra estudar as grandes religiões eu acho que seria bom, dentro da área de filosofia, e não dentro da área de história, porque dentro da área de história é impregnada por valores ideológicos"

É possível notar que para P3 a discussão sobre religião deve ter um espaço na escola sim, na disciplina de filosofia. No entanto, para a professora, esse espaço seria para discutir as questões profundas das grandes religiões, sua filosofia. A professora não cita a discussão sobre tolerância religiosa.

Por fim, segundo a diretora da escola, a laicidade está no fato de a escola não estimular nem "cobrar" nenhum tipo de religião. Ela acha que é falado de modo geral de todas religiões e respeitado todas elas.

"Eu considero a escola laica porque a gente não estimula nenhuma, nenhum tipo de religião, nem cobra um tipo de religião. Eu acho que é falado de modo geral de todas religiões e respeitado todas elas."

A visão de laicidade da diretora, portanto, concebe como um espaço onde é falado de modo geral de todas as religiões, onde todas tenham espaço.

É possível notar, portanto, concepções de laicidade como neutralidade das religiões na escola, sem o estímulo a nenhuma. No entanto, o modo é diferente. Enquanto P1 diz falar de religião como um pano de fundo da disciplina, P2 a considera de foro íntimo, P3 gostaria de um espaço para se falar das filosofias das grandes religiões e a direção em não estimular nenhuma religião.

Por essas entrevistas, podemos perceber que a intolerância religiosa não é percebida como um problema central entre professores e direção da escola. No entanto, a maior parte citou casos de "brincadeiras" entre os alunos envolvendo a religião deles.

Na próxima seção serão analisadas as entrevistas de quatro alunos da turma 802, a fim de entender melhor suas concepções e suas percepções da realidade da escola.

\subsection{2.}

\section{Entrevistas com os alunos}

As entrevistas semiestruturadas foram realizadas com quatro alunos da turma 802 em momentos disponibilizados pelos professores das turmas, de forma individual, na sala dos professores e apenas com a presença do pesquisador e 
do(a) entrevistado(a). Os alunos que aceitaram dar a entrevista não demonstraram medo ou receio, aparentando estarem à vontade para conversar.

Em se tratando dos alunos entrevistados, a aluna A1, 15 anos, é branca e declarou não ter religião. A2, parda, 14 anos, é evangélica e frequenta a igreja Paz e Amor. A aluna A3, parda, 14 anos, é evangélica da Assembleia de Deus do Leblon. A aluna A4 é negra, 14 anos, é católica, como pode ser visto no apêndice 6.

A1, a aluna trans, diz que mora só com a mãe "graças a Deus", pois o pai é homofóbico. Ela não fez o $7^{\circ}$ ano na escola e, portanto, não respondeu ao questionário do ano 2017. Ela estudou a maior parte da vida em escola pública e apenas o $7^{\circ}$ ano cursou em uma escola particular. Em sua opinião, a escola pública é melhor, pois os alunos têm mais liberdade para conversarem. Quando perguntada sobre a relação com os colegas, disse ser boa. No entanto, relata ouvir muitas "brincadeirinhas", como "bixa" "bixinha" "viadinho". Quando perguntada se isso a incomoda, disse que não, pois responde que é "bichérrima". É interessante notar que a aluna não classifica esses xingamentos como homofobia. A aluna ressignifica essas ofensas, assumindo sua homossexualidade.

Sobre a relação dos colegas da turma entre si disse que é "média", pois os alunos se ofendem uns aos outros. Cita, além dos xingamentos em relação à sexualidade, a questão da raça "preto", "tizil" e "azul".

Sobre a importância da religião em sua vida, em uma escala de 0 a 10, atribuiu a importância de 3,5. Sobre esse assunto a aluna disse

“A1: Assim, não me considero uma pessoa religiosa, mas sim me considero uma pessoa com a minha própria fé em Deus.

F: Como é que é você definiria essa sua fé em Deus?

A1: Assim, é...acreditar nas verdadeiras palavras da bíblia, sendo que eu faço algumas coisas ao contrário.

F: É? O que você faz o contrário?

A1: Sou homossexual.

F: Isso te gera uma culpa, alguma coisa?

A1: Não...porque...eu não escolhi ser assim. Na verdade, não vamos dizer que eu nasci assim, mas desde pequeno eu sempre tive esse...esse...esse lado afeminado.

F: Aham. E qual é sua religião?

A1: Nenhuma."

É possível notar que há um conflito interno em sua relação com a religião.

Por um lado, acredita em Deus e na Bíblia. Por outro, a aluna considera que está desagradando Deus com a sua homossexualidade e também se considera sem religião. 
Quando perguntada se já presenciou preconceito na escola, cita novamente as "brincadeiras" com sua orientação sexual. A aluna atribui esse comportamento dos outros alunos em relação a ela com a religião evangélica.

"Geralmente, é...eles jogam muito a bíblia no peso da gente. Ele joga a bíblia pro lado da gente...tipo...culpando a gente. Eu sei que a gente não tá certa, né? Mas...é porque...eles gostam muito de julgar a gente pelas palavras que nem eles mesmo segue...é...direto."

Apesar de não identificar diretamente um preconceito religioso em seu ambiente escolar, a aluna identifica um preconceito em relação à orientação sexual, que vem de valores religiosos, principalmente partindo de estudantes evangélicos. É possível notar um conflito interno da aluna na relação entre religião e sua sexualidade. Apesar de não se considerar religiosa, a aluna diz que "sabe não estar certa" quanto à sua sexualidade, e o parâmetro para não estar certa é a bíblia.

A aluna A2 mora com a mãe e padrasto e estudava na escola no $7^{\circ}$ ano em 2017. Veio do Pará, e lá estudava em escola particular. Acha as pessoas do Rio mais simpáticas e receptivas. Diz que sua relação com a turma é boa, que tem amizade com todo mundo. É evangélica, frequenta a Igreja Paz e Amor. Atribui 8, na escala de 0 a 10 sobre a importância da religião na sua vida. Diz que isso não influencia em nada o seu comportamento na escola ou sua relação com as disciplinas pois "respeita todas as religiões".

Em relação a ver preconceito no cotidiano escolar, a aluna relata que existe preconceito com o corpo, como uma aluna da sua sala que usa óculos e os outros alunos a zoam. Cita também o caso de A1, que "escuta piadas de todos da turma". Diz que não reage à essas situações, mas que não gosta quando acontece. Nunca viu preconceito religioso e nunca sofreu preconceito de nenhum tipo. A fala dessa aluna vai na direção da fala dos professores. Apesar do preconceito não ser avaliado como um grande problema, ele é identificado, ele existe naquele ambiente. A aluna não relata a ação de nenhum professor contra isso.

A3 mora com sua mãe e irmãos. Sempre estudou em escola pública, e estava na escola há dois anos. Estudava antes em um CIEP no Vidigal, bairro onde mora. Considera a escola Água Viva de mais qualidade, pois os professores explicam melhor. 
A estudante diz que sua relação com a turma é boa, ainda que dividida em "grupinhos". Ela relata que as pessoas não se respeitam, que colocam apelidos umas nas outras. Cita também o caso de A1, que ouve "piadas" dos colegas o tempo todo.

A aluna atribui a importância da religião na sua vida a nota 10 , se considera muito religiosa. Diz que frequenta a Assembleia de Deus cinco vezes por semana e que isso não afeta em nada sua relação com as disciplinas. No entanto, diz se comportar melhor por "ser da igreja".

A3 diz que presencia preconceito na escola "com tudo". Diz que não gosta, não participa das situações de apelidos e xingamentos, mas também não faz nada para defender os colegas que são alvos.

A aluna A4 mora com a mãe e o pai. Estava na escola desde o $6^{\circ}$ ano. A aluna veio de Minas Gerais em 2015. Diz que a relação dos colegas é boa, mas que a turma é muito "bagunceira". Ela é católica, mas não frequenta a igreja "há um tempão". No entanto, atribui a nota 10 para a importância da religião na sua vida. Diz que isso não altera nada no seu comportamento na escola, e nem na sua relação com as disciplinas.

A aluna diz nunca ter visto preconceito na escola, apenas "brincadeiras". Cita o caso de A1, quando os alunos a xingam de "viado". Mas diz que não considera isso preconceito, pois A1 "não fica triste" e "gosta das brincadeiras". Ela afirma, ainda, não participar dessas brincadeiras. É interessante notar que A4 só considera preconceito se uma atitude causa impacto muito negativo na vítima. O preconceito não estaria apenas nos xingamentos e falas, mas dependeria da relação da vítima com eles. Isso, em certo sentido, tira a responsabilidade desta aluna e a passa para a vítima, liberando-a de um sentimento de conivência.

Podemos ver, por essas entrevistas, que os quatro alunos entrevistados identificam "brincadeiras" desagradáveis no ambiente escolar. Apesar de nem todos as identificarem como preconceito, elas são invariavelmente destacadas. É interessante notar como existem concepções diferentes de preconceito entre esses alunos. A1 chama os xingamentos que recebe de "brincadeiras", e as identifica quando perguntada sobre a existência de preconceito. A2, por sua vez, identifica as brincadeiras contra o corpo como preconceito, enquanto A3 diz presenciar preconceito com tudo. Esses três alunos identificam essas situações de xingamentos e brincadeiras como preconceito. Já A4, como abordado 
anteriormente, identifica o preconceito na relação entre a brincadeira e a reação da vítima. Outro ponto que podemos destacar é a centralidade de A1 nas relações da turma. Todos os entrevistados a citaram como exemplo das brincadeiras no ambiente escolar.

Nenhum entrevistado identificou a religião como um fator de preconceito. $\mathrm{O}$ preconceito de orientação sexual sim é visto por esses alunos como tema recorrente. É importante notar, no entanto, que A1 identifica uma raiz religiosa nesse preconceito sofrido por ela. Foi possível notar nessa turma que a forte afirmação de A1 em relação à sua sexualidade gera a identificação da aluna como alvo de preconceito.

Podemos identificar tanto nas falas dos professores como dos alunos que ambas as partes identificam determinadas situações de preconceito, até atribuem certa gravidade a elas em determinados momentos, mas não parece haver um movimento para discuti-lo, desconstruí-lo ou algo do tipo. Isso, num certo sentido, dá a entender de que o preconceito faz parte do cotidiano escolar e os agentes escolares o naturalizam.

$\mathrm{Na}$ fala dos professores é possível notar que eles reconhecem que o preconceito existe, mas quando ocorre na sala de aula não conseguem atuar de forma efetiva sobre essas situações.

Além disso, os relatos sobre a gestão anterior e suas ideias sobre Deus e religião e a "oficina" que observamos mostram como os valores religiosos podem ser acionados por diferentes agentes na escola para tentar controlar o comportamento e expectativas de realizações futuras dos alunos. Isso se distingue da fala dos professores, que apresentam muito mais receio de falar sobre religião. 


\section{6 \\ Conclusão}

Essa seção irá apresentar algumas conclusões da pesquisa. Para isso iremos retornar às nossas questões e aos nossos objetivos de pesquisa.

As questões de pesquisa apresentadas no capítulo 1 desse trabalho eram:

- Como a diferença religiosa é entendida por esses alunos? Como eles encaram o outro, o diferente de si?

- Os fatores do cotidiano escolar influenciam na construção de concepções conflituosas e intolerantes?

Dessas questões decorreram os seguintes objetivos:

1) Identificar as relações, e os conflitos da religião no espaço escolar

2) Analisar as concepções de alunos do $7^{\circ}$ ano sobre religião

3) Observar o espaço escolar e a influência da escola na concepção dos alunos sobre diversidade religiosa;

Tentamos responder a essas questões de pesquisa através dos questionários, observações das salas e entrevistas com os alunos. A primeira questão se relaciona aos objetivos 1 e 2 e a segunda questão ao objetivo 3 .

Em relação à primeira pergunta, como os alunos se relacionam com as religiões, é possível notar, através dos questionários de 2017, que a maior parte dos alunos responde de maneira tolerante às afirmações do questionário. No entanto, podemos fazer alguns destaques. De um universo de 1000 alunos 30\% concordam com a frase "quem não acredita em Deus vai para o inferno", 20\% acreditam que todas as pessoas devem ter uma religião, $17 \%$ que só existe uma religião verdadeira. Outros $30 \%$ concordam que o candomblé é uma religião do demônio. Tais dados apontam que, apesar de a maior parte responder de forma tolerante, a intolerância também está presente na escola.

Outra questão interessante é quanto à crença. Na afirmação ": É melhor acreditar na Bíblia do que na Ciência" 50,2\% concordam com a afirmação". Em um universo de $55 \%$ de cristãos, isso mostra uma forte crença na bíblia como detentora do conhecimento para esses estudantes.

Um terceiro dado interessante é quanto ao hábito de rezar em sala de aula. Em relação à afirmação "É bom quando a professora reza na aula com os alunos", $52 \%$ apresentaram concordância. Esse dado indica que há uma reação positiva em 
relação à presença de momentos de oração no espaço escolar por parte desses alunos.

Já com os dados da escola Água Viva em 2017 podemos ver algumas mudanças em relação ao universo geral. Na afirmação "todos têm que ter uma religião" há mais alunos que concordam no Água Viva do que no universo geral, de $19 \%$ para $34 \%$ no colégio Água Viva. Na afirmação “quem não acredita em Deus vai para o inferno" há um aumento de $27 \%$, no universo geral, para $55 \%$ no colégio Água Viva. Já na frase “o candomblé é uma religião do demônio" a porcentagem se diferencia de $30 \%$ para $48 \%$. Ou seja, quase metade dos estudantes que responderam o questionário no colégio Água Viva acreditam que o candomblé é uma religião do demônio. Já se os alunos do candomblé podem usar suas guias na escola, a porcentagem de concordância no geral chega a quase $60 \%$. No Colégio Água Viva cai para $42 \%$.

Através dos questionários de 2018 da escola Água Viva também pudemos perceber que, em geral, as respostas dos alunos tendem a respostas tolerantes. Em todas as situações, há uma porcentagem maior de alunos que respondem de acordo com parâmetros mais tolerantes em relação às religiões.

No entanto, quando analisamos as respostas por opção religiosa dos alunos, é possível obter alguns dados interessantes. Na afirmativa número 2, por exemplo, "quem não acredita em Deus vai para o inferno", temos um índice geral de discordância de 80,5\%. No entanto, entre os evangélicos, o índice de discordância diminui para 55,5\%. Na afirmativa número quatro, "o candomblé é uma religião do demônio", o mesmo acontece. Enquanto o índice geral de discordância é de $80,6 \%$, entre os evangélicos esse índice cai para $66 \%$. Na afirmativa número oito "quem acredita em imagens de santos não vai para o céu" a discordância geral é de $80,5 \%$, e entre os evangélicos cai para $66,6 \%$.

Essas situações nos indicam que alguns conceitos chaves na teologia evangélica afetam a aceitação de outras religiões por parte desses alunos. As perguntas citadas se referem a outras religiões, acompanhadas de conceitos como céu, inferno, demônio e santos.

Um outro indicador importante é em relação a aceitação das religiões africanas no ambiente escolar. Sobre esse tópico podemos citar duas afirmações presentes no questionário. A afirmação de número cinco diz que "alunos de candomblé e umbanda podem usar suas guias na escola". Nessa afirmação o 
índice geral de concordância da afirmação é de 55,6\%. Os católicos mantêm esse índice. Já entre os evangélicos, a concordância cai para 44,5\%.

A afirmação de número seis diz que "alunos evangélicos podem fazer trabalhos sobre religiões africanas”. Nessa questão, o índice geral de concordância foi de 77,8\%. Entre os evangélicos, no entanto, a concordância cai para 55,5\%.

O maior índice de intolerância religiosa em relação a religiões de matriz africana por evangélicos pode ser encontrada em outras pesquisas, como De Oliveira (2013), Santos(2017) e Quintana(2013).

Por fim, outra questão que traz um índice interessante é a afirmativa número sete "é melhor acreditar na bíblia do que na ciência". Essa questão não falava sobre tolerância, ou intolerância, mas sobre a relação entre religião e conhecimento. No geral, 44,4\% dos alunos discordam da afirmação e 55,5\% concordam com ela, um índice, mesmo que bem equilibrado, que pende para a maior aceitação da ciência em relação a bíblia. Esse índice se repete em relação aos católicos. Já entre os evangélicos, o grau de concordância com a afirmação chega a $88,9 \%$. Ou seja, há um indício de que alunos evangélicos tem uma maior dificuldade de aceitar a ciência como fonte de conhecimento. Essa é uma conclusão que foi também percebida em pesquisas anteriores, como Teixeira e Andrade (2014) e Dorvillé e Teixeira (2015).

Com relação às observações e entrevistas com os alunos, as observações não apontaram a discussão sobre religião como um tema recorrente em sala de aula. Os comentários dos alunos se faziam esporadicamente, como visto no capítulo 5.

As entrevistas com quatro alunos apontaram eles identificam "brincadeiras" desagradáveis no ambiente escolar. Apesar de nem todos as identificarem como preconceito, elas são invariavelmente destacadas. É interessante notar como existem concepções diferentes de preconceito entre esses alunos. A1 chama os xingamentos que recebe de "brincadeiras", e as identifica quando perguntada sobre a existência de preconceito. A2 identifica as brincadeiras contra o corpo como preconceito. A3 diz presenciar com tudo. Esses três alunos identificam essas situações de xingamentos e brincadeiras como preconceito. Já A4, como abordado anteriormente, identifica o preconceito na relação entre a brincadeira e a reação da vítima.

Em relação à primeira questão de pesquisa, portanto, os questionários e entrevistas apontam que a intolerância é algo presente nas concepções dos alunos 
em relação às outras religiões. A religião dos jovens participantes da pesquisa influencia suas concepções, como evidenciam as comparações entre os percentuais de concordância para as afirmativas de acordo com cada grupo de religião. No entanto, é necessário apontar que, apesar dessa presença confirmada de concepções intolerantes, em termos majoritários há uma tendência pela tolerância religiosa.

Podemos observar também, como apontado durante o capítulo 5 e na presente conclusão, que no caso da turma observada houve uma série de situações de preconceito com relação à identidade de gênero de uma aluna em específico. Segundo a própria aluna, o preconceito sofrido por ela tem razões religiosas e que percebe isso nas falas de outros alunos em relação a ela. O mesmo é apontado pela professora P2, ao dizer que os alunos da sala perguntavam para A1 qual sua religião, se ela tinha relação com o Diabo.

Já a segunda questão - se os fatores do cotidiano escolar influenciam na construção de concepções conflituosas e intolerantes - foi respondida parcialmente com essa pesquisa. Através da divisão das respostas por religião, feita no capítulo 4 , é possível notar que a religião do próprio aluno influencia as suas concepções. No entanto, podemos também apontar o tratamento que a escola faz da questão, através das entrevistas com professores e direção.

$\mathrm{O}$ professor $\mathrm{P} 1$ disse nunca ter presenciado preconceito, mas que há um deboche constante com as religiões de matriz africana. Ele afirma que essas "ideias sobre as religiões africanas" vem de fora, que os alunos trazem para dentro da escola. O professor alega que logo coíbe as brincadeiras, para que "elas não se tornem preconceitos". No entanto, ele não classificou esse "deboche" como preconceito.

P2 também diz que nunca presenciou preconceitos religiosos em sua sala de aula. No entanto, diz serem constantes os comentários de "brincadeira" sobre religiões. Segundo a professora, os casos mais comuns estão relacionados com a Igreja Universal e com as religiões que ela chama de "espíritas".

Já a diretora adjunta relata "presenciar alguns bate-bocas" entre evangélicos e praticantes de religiões africanas. No entanto, não soube especificar um exemplo e não classificou a prática como "preconceito", mas como uma relação normal entre adolescentes. 
Podemos notar, com esses relatos, que existem conflitos e tensões religiosas no ambiente escolar. No entanto, são interpretados como comportamentos de adolescentes. Segundo professores e direção, eles se preocupam sim e dialogam com os alunos sobre suas falas, mas não é uma preocupação central. A problemática da intolerância religiosa não é identificada por esses atores como um grande problema no ambiente escolar.

É interessante também notar que P1, P2 e a diretora adjunta disseram que essas brincadeiras incluem mais constantemente alunos de religiões de matriz africana. Todavia, P2 também incluiu alunos da Igreja Universal como alvo das brincadeiras. Este é um ponto interessante, já que os evangélicos, mesmo que muitas vezes apontados como autores de práticas intolerantes, também podem sofrer preconceitos no ambiente escolar.

Os professores lidam com a questão da religião de maneiras diferentes. Em relação à presença da discussão sobre diversidade religiosa no currículo, P1disse que em muitos momentos do currículo de história é trabalhada a questão da diversidade. Já P2 associa falar de religião com os alunos com uma possível tentativa de conversão. A professora diz que evita falar sobre o assunto para não parecer que os está influenciando. Para P3 o assunto não deve ser tratado, pois a religião gera uma polêmica na escola.

Nesse sentido, a religião, na visão desses agentes escolares e a partir da observação de suas aulas, não é explorada de forma tão direta quanto possível, sendo evitada ou tratada como "pano de fundo". Aqui cabe, portanto, um questionamento que pode ser levado a frente por pesquisas futuras. Se se pretende que a escola seja um espaço para a construção da tolerância religiosa, como isso seria possível sem falar diretamente da religião? Falar das religiões já implicaria criticá-las? Não se pode criticar as religiões? É preciso reconhecer, porém, que no momento atual, em que a atividade e autoridade docentes são questionadas por diferentes grupos sociais, ser professor e abordar essa temática em aula, pode ser uma caminhada em um campo minado.

É difícil, portanto, precisar em que medida há influência da escola nas concepções religiosas de seus alunos. No geral, é possível apontar uma atitude de distância da discussão sobre intolerância religiosa no espaço escolar.

Essa dissertação de mestrado também destaca a importância da diversidade cultural, mais especificamente a religiosa, no cotidiano escolar. Dessa maneira, 
oferece elementos para se refletir sobre a formação de professores e gestores, tendo em vista o reconhecimento das diferentes crenças na escola e de sua influência nas relações entre estudantes e desses com professores. As situações de preconceito observadas, bem como a dificuldade de lidar com a intolerância religiosa, como expressado pelos professores, indica que o estudo das relações entre escola e religião em cursos de formação pode contribuir para a construção de novas práticas e orientações pedagógicas.

A presente pesquisa, portanto, deixa algumas indicações para futuras pesquisas que queiram se aprofundar nessa questão. A influência do espaço escolar e as diferentes formas de lidar com a questão da intolerância pode ser explorada a partir de outras perspectivas que busquem explorar de diferentes maneiras possíveis tensionamentos entre grupos religiosos e as diferentes concepções deles acerca de situações ocorridas no próprio cotidiano escolar. Há escolas com projetos bem-sucedidos de promoção da tolerância religiosa? Quais suas características? Qual o impacto do preconceito religioso na trajetória acadêmica dos estudantes?

Considerando-se os relatos de preconceito com relação a alunos de religiões de matriz africana, novos estudos podem ser conduzidos em contextos escolares com grande presença de estudantes desses credos. Como lidam com a presença da religião na escolas? Quais as maneiras de se abordar o assunto?

Como uma instituição social, a escola possui suas próprias práticas e formas de organização. Entendemos aqui a cultura escolar como aquele conjunto de práticas, normas, ideias e procedimentos que se expressam em modos de fazer e pensar o cotidiano da escola, mas, além disso, compreendemos a escola e suas práticas como um local de conflito, um local onde diferentes perspectivas se encontram, sendo constituinte de sua "cultura". É na cultura escolar, nesse espaço de símbolos, comportamentos e perspectivas, que investigamos a presença (ou não) da tolerância, e a preocupação dos agentes escolares com esse comportamento.

Além de sua organização cultural própria, a escola é um ambiente multicultural, o que significa dizer que muitas vezes ela faz o papel de mediação de diferentes visões de mundo que ali estão. No caso do objeto aqui estudado - a religião - sabemos de inúmeros casos onde essa "mediação" não é feita com sucesso, gerando casos de intolerância. $\mathrm{Na}$ nossa perspectiva, é nessa lógica 
própria da escola, que abriga interseções culturais, o lugar da promoção da tolerância. 


\section{Referências}

ALVES, JED, CAVENAGHI, S, BARROS, LFW, CARVALHO, A.A. Distribuição espacial da transição religiosa no Brasil, Tempo Social, revista de sociologia da USP, v. 29, n. 2, 2017, pp: 215-242.

ANDRADE, Marcelo. Tolerar é pouco? Pluralismo, mínimos éticos e práticas pedagógicas. Rio de Janeiro: DP\&Alli, 2009.

ANDRADE, M.; TEIXEIRA, P. P. A escola num mundo secular e religioso: Poderia ser a tolerância uma alternativa? Teias, v. 15, n. 36, p. 61-79, 2014 ANDRE, Marli. "Estudo de Caso: Seu Potencial na Educação". In: Caderno de Pesquisa,1984, n.49, p. 51-54

BARBOSA, Rui, "Reforma do ensino secundário e superior". In: obras completas. 188211942, vol. IX, tomo'. Rio de Janeiro: MES, 1942, p, 276.

BRASIL. Lei de 15 de outubro de 1827. Disponível em <:http://www.planalto.gov.br/ccivil_03/leis/LIM/LIM-15-10-1827.htm:>. Acesso em 23/02/16.

BRASIL. Constituição Federal de 1891. Promulgada em 24 de fevereiro de 1891. Disponível em:

<http://www.planalto.gov.br/ccivil_03/constituicao/constituição.htm>.

BERGER, Peter. A dessecularização do mundo: uma visão global. Religião e sociedade, v. 21, n. 1, p. 9-24, 2000.

BERGER, Peter L. O Dossel Sagrado: elementos para uma sociologia da religião. São Paulo: Paulinas, 1985

BLANCARTE, Roberto. Discriminación por motivos religiosos y EstadoLaico: elementos para uma discusión. Estudios sociológicos, v. XXI, n.62, 2003, p.279307.

BONAMINO, Alícia Maria e OLIVEIRA, Lúcia Helena. Estudos longitudinais e pesquisa na educação básica. Linhas Críticas, Brasília, v. 19, n. 38, jan./abr. 2013, p. 33-50.

BONI, Valdete; QUARESMA, Sílvia Jurema. Aprendendo a entrevistar: como fazer entrevistas em Ciências Sociais. Em Tese, v. 2, n. 1, p. 68-80, 2005.

BRASIL, Relatório sobre Intolerância e Violência Religiosa no Brasil (2011 2015): Resultados Preliminares, Brasília, 2016.

CARDOSO, Oldimar e PENIN, Sonia T. de S. A sala de aula como campo de pesquisa: aproximações e a utilização de equipamentos digitais. Educação e Pesquisa, São Paulo, v. 35, n. 1, jan./abr., 2009. 
CANDAU, Vera Maria. Cotidiano escolar e cultura(s): encontros e desencontros.in: CANDAU, Vera Maria (org). Reinventar a escola. 3 .ed. Petrópolis: Vozes,2002,p.61-79

CASANOVA, José. O problema da religião e as ansiedades da democracia secular europeia. Revista de Estudos da Religião, v. 10, p. 1-16, 2010.

CASANOVA, José. Public religions in the modern world. University of Chicago Press, 2011.

CAVALIERE, Ana Maria. O mal-estar do ensino religioso nas escolas públicas. Cadernos de Pesquisa. São Paulo, v. 37, n. 131, mai./ago., 2007.

CAPUTO, Stela Guedes. Questões sobre gestão, formação e avaliação a respeito do ensino religioso na escola pública do Rio de Janeiro. Revista da FAEEBA.Salvador, n.38, 2013

CAPUTO, Stella Guedes. Aprendendo yorubá nas redes educativas dos terreiros: história, culturas africanas e enfrentamento da intolerância nas escolas. Rev. Bras. Educ. vol.20, n.62, 2015.

CARDOSO, Clodoaldo Meneguello. Tolerância e seus limites: um olhar latinoamericano sobre a diversidade e a desigualdade. São Paulo: UNESP, 2003.

CARVALHO, José Jorge de. Antropologia e esoterismo: dois contradiscursos da modernidade. Horiz. antropol., Porto Alegre , v. 4, n. 8, p. 53-71, June 1998

COELHO, Wilma de Nazaré Baía; COELHO, Mauro Cezar. Preconceito e discriminação para além das salas de aula: sociabilidades e cultura juvenil no ambiente escolar. Rev. Inst. Estud. Bras., São Paulo , n. 62, p. 3253, Dec. 2015

COSTA, Maria Guilhermina Guedes Maia da. A tolerância como paradigma antropológico: contributo para a construção de uma filosofia da educação. 1999. 160f. Dissertação (Mestrado em Letras)- Faculdade de Letras, Universidade do Porto, Porto, 1999.p. 31.

CUNHA ,Clara B. e BARBOSA, Cláudia. O ensino religioso na escola pública e suas implicações em desenvolver o senso de respeito e tolerância dos alunos em relação aos outros e a si próprios. RevistaSacrilegens, Juiz de Fora,v. 8, n. 1, dez./ 2011.

CUNHA, Luiz Antônio e FERNANDES, Vânia Cláudia. Um acordo insólito: ensino religioso sem ônus para os cofres públicos na primeira LDB. Educação e Pesquisa. São Paulo, USP,n. 4, vol. 38, out/dez, 2012.

CUNHA, Luiz Antônio. Ensino religioso nas escolas públicas: a propósito de um seminário internacional. Educação e Sociedade. Campinas, n. 97, set./dez., 2006. O artigo focaliza cinco países: Estados Unidos, Grã-Bretanha, França, Alemanha e Itália. 
CURY, Carlos Roberto Jamil. "Ensino Religioso e Escola Pública: o curso histórico de uma polêmica entre Igreja e Estado no Brasil". In: Educação em Revista. n. 17, p. 20-37, jun. 1993,p.22.

CURY, Carlos Roberto Jamil. "Ensino religioso na escola pública: O retorno de uma polêmica recorrente". In: Revista Brasileira de Educação. n. 27, p. 183191, set./out./nov./dez. 2004.

DAL-FARRA, R. A., LOPES, P. T. C. Métodos mistos de pesquisa em educação: Pressupostos teóricos. Nuances: Estudos sobre Educação, n24,p. 67-80, 2013.

DE OLIVEIRA PIRES, Thula Rafaela; MORETTI, Gianna Alessandra Sanchez. Escola, Lugar do Desrespeito: Intolerância Contra Religiões de Matrizes Africanas e Escolas Públicas Brasileiras. Revista de Direitos Humanos e Efetividade, v. 2, n. 1, 2016.

DINI, Ariane Polidoro et al. Validade e confiabilidade de um instrumento de classificação de pacientes pediátricos. Revista Latino-Americana de Enfermagem, v. 22, n. 4, p. 598-603, 2014.

DORVILLÉ, Luís Fernando M.; TEIXEIRA, Pedro. O crescimento do criacionismo no Brasil: principais influências e avanços recentes. $\mathbf{X}$ Encontro Nacional de Pesquisa em Educação em Ciências, p. 24-27, 2015.

DUARTE, Rosália. Entrevistas em pesquisas qualitativas. In: Educar, Curitiba, n. 24, p. 213-225, 2004.

FERREIRA NETO, E. (2012). Secularização e fundamentalismo religioso. Angelus Novus, (3), 323 - 335.

FONSECA, S. G. O trabalho do professor na sala de aula: relações entre sujeitos, saberes e práticas. In: Revista Brasileira de Estudos Pedagógicos, Brasília, v. 91, n. 228, p. 390-407, maio-ago., 2010

FISHMANN, Roseli (org). Ensino Religioso em escolas públicas: ameaças ao Estado Laico. Notandum no 28, jan/abr, 2012.

FLORES, Elio Chaves. Etnicidade e ensino de História: a matriz cultural africana. Revista Tempo, v. 16, n. 21, p. 75-91, 2006

FONSECA, J. J. S. Metodologia da pesquisa científica. Fortaleza: UEC, 2002.

FORQUIN, Jean Claude. Escola e cultura: As bases epistemológicas do conhecimento escolar. Porto Alegre, Artes Médicas, 1993.

GEERTZ, C. A interpretação das culturas. A interpretação das culturas Rio de Janeiro: Jorge Zahar, 1978.

GIMENO SACRISTÁN, J. Docencia y cultura escolar:reformas y modelo educativo.Buenos Aires: Lugar, 1997 
GIUMBELLI, Emerson. Fronteiras da laicidade. Revista Brasileira de Ciências Sociais, v. 27, n. 79, p. 205-208, 2012.

A presença do religioso no Espaço Público: modalidades no Brasil. Religião e Sociedade, vol. 28, n.2: 80-100, 2008.

HALL, Stuart. A identidade cultural na pós-modernidade. Rio de Janeiro: D P \& A, 9a. ed. 2004.

HARBERMAS, Jürgen. Fé e saber. São Paulo: Editora Unesp, 2013

HOBSBANW, Eric. Era dos extremos: O breve século XX(1914-1991). São Paulo: Cia das Letras, 1955.

IBGE - Instituto Brasileiro de Geografia e Estatística. Pesquisa Nacional por Amostra de Domicílios. Síntese dos Indicadores de 2009. Rio de Janeiro: IBGE; 2010 [acesso em 4 jan 2019]

Instituto Brasileiro de Geografia e Estatística (IBGE): Tabela 1.4.1 População residente, por situação do domicílio e sexo, segundo os grupos de religião Brasil (2010). Disponível em:

$<$ http://www.ibge.gov.br/home/estatistica/indicadores/trabalhoerendimento/pnad_ continua/primeiros_resultados/defaulttab.shtm:> Acesso em 16/01/16.

JACOB, C. R. et al. Atlas da filiação religiosa e indicadores sociais do Brasil. Rio de Janeiro; São Paulo: Ed. PUC-Rio; Loyola, 2013.

KOSELLECK, Reinhart." Uma história dos conceitos: problemas teóricos e práticos". In: Estudos históricos. Vol. 5, n. 10, p. 134-146

LEE, Valerie E. A necessidade dos dados longitudinais na identificação do efeitoescola. Revista Brasileira de Estudos Pedagógicos, v. 91, n. 229, 2010.

LÜDKE, Menga e ANDRÉ, Marli. Pesquisa em educação: abordagens qualitativas, São Paulo: EPU, 1986.

LAUREANO, Marisa Antunes. O ensino de História da África. Ciências \& Letras, n. 1, 2008.

LIMA, JOSELIA BARROSO QUEIROZ. SONS DO SILÊNCIO: A RELAÇÃO ENTRE RELIGIÃO CATÓLICA E EDUCAC̨ÃO ESCOLAR UM ESTUDO DE CASO' 262 f. Doutorado em EDUCAÇÃO Instituição de Ensino: UNIVERSIDADE ESTADUAL DE MARINGÁ, 2013.

LOCATELLI, Piero.; MARTINS, Rodrigo. "O poder dos evangélicos na política". Carta Capital, 12 de agosto de 2014. Disponível em: $>$ http://www.cartacapital.com.br/revista/811/alem-do-misticismo-9696.html>. Acesso em: $16 / 01 / 16$. 
LOCKE, John. (1973), “Carta acerca da tolerância”. In: Os Pensadores. São Paulo: Abril Cultural. 50

MACHADO CORDEIRO, Aliciene Fusca; FORTUNATO BUENDGENS, Jully. Preconceitos na escola: sentidos e significados atribuídos pelos adolescentes no ensino médio. Psicologia Escolar e Educacional, v. 16, n. 1, 2012.

MALHEIROS, B. T. Metodologia da Pesquisa em Educação, 2a ed. Rio de Janeiro: LTC, 2011, p. 134-150.

MARCONDES, Maria Inês; TEIXEIRA, Elizabeth; OLIVEIRA, Ivanilde Apoluceno de. Metodologias e técnicas de pesquisa em educação. Belém: EDUEPA, 2010.

MARIANO, R. Neopentecostais : sociologia do novo pentecostalismo no Brasil. São paulo: Loyola, 1999.

MARIANO, R. Análise sociológica do crescimento pentecostal no Brasil. [s.l.] Universidade de São Paulo, 2001

MARIANO, Ricardo. Guerra espiritual: o protagonismo do diabo nos cultos neopentecostais. Debates do NER, v. 2, n. 4, 2003.

MARIANO, Ricardo. "Expansão pentecostal no Brasil: o caso da Igreja Universal". In: Estudos Avançados. São Paulo, v. 18, n. 52, p. 121138, Dez. 2004.

MARIANO, Ricardo. Laicidade à brasileira. Católicos, pentecostais e laicos em disputa na esfera pública. Civitas, v. 11 n. 2. Porto Alegre, pp. 238-258, 2011.

MARIANO, Ricardo. Laicidade à brasileira. Católicos, pentecostais e laicos em disputa na esfera pública. Revista Civitas: Porto Alegre, V.11 n.2, 2011.

MARIANO, Ricardo. Crescimento pentecostal no Brasil: fatores internos. Revista de Estudos da religião, v. 4, 2008.

MARIZ, Cecília Loreto. Secularização e dessecularização: comentários a um texto de Peter Berger. Religião e sociedade, v. 21, n. 1, p. 25-39, 2000.

MENEZES, Paulo. "Filosofia e tolerância".In: Síntese Nova Fase, v. 23, n. 72, p. 6, 1996.

MONTERO, Paula. Secularização e espaço público: a reinvenção do pluralismo religioso no Brasil. Etnográfica. Revista do Centro em Rede de Investigação em Antropologia, v. 13, n. 1), p. 7-16, 2009.

MORE, Thomas. A Utopia, Rio de Janeiro: Edições de Ouro, 1971, p.51.

MONIZ, Jorge Botelho. As falácias da secularização: análise das cinco críticastipo às teorias da secularização. Política \& Sociedade, v. 16, n. 36, p. 74-96, 2017. 
MUNIZ, Tamiris Alves. "Educação religiosa e estado laico". In: III Congresso Internacional de História da UFG, Jataí, 2012(Anais)

MUNIZ, Tamiris Alves. A disciplina ensino religioso no currículo escolar brasileiro: institucionalização e permanência. 2014. 206 f. Dissertação (Mestrado em educação), Universidade Federal de Goiás, Goiânia. 2014.

NOBRE, ADILSON DOS REIS. LAICIDADE E RELIGIOSIDADE EM ESCOLAS PÚBLICAS : um estudo de caso sobre práticas religiosas pentencostais e sua relação com a cultura escolar' $.180 \mathrm{f}$. Mestrado em Educação Instituição de Ensino: UNIVERSIDADE DO ESTADO DE MINAS GERAIS, Belo Horizonte, 2013.

NUNES, Clarice." Historiografia comparada da escola nova: algumas questões". In: Revista Faculdade de Educação. Jan 1998, vol.24, no.1

OLIVA, Anderson Ribeiro. A História da África nos bancos escolares. Representações e imprecisões na literatura didática. 2003.

ORO, Ari Pedro. A laicidade no Brasil e no Oriente: algumas considerações. Civitas: revista de ciências sociais. Porto Alegre, RS. Vol. 11, n. 2 (maio/ago. 2011), p. 221-237, 2011.

OUTHWAITE, William. Dicionário do pensamento social do século XX. Zahar, 1996.

OLIVEIRA, Marlon Anderson de. "Entre a Coroa e a Cruz: A igreja colônia sob a égide do padroado". In: Mneme - Revista de Humanidades- UFRN. Caicó (RN), v. 9. n. 24, Set/out. 2008, p.1.

ORDEIRO, Aliciene Fusca Machado; BUENDGENS, Jully Fortunato. Preconceitos na escola: sentidos e significados atribuídos pelos adolescentes no ensino médio. Psicol. Esc. Educ., Maringá , v. 16, n. 1, p. 45-54, June 2012.

PIERUCCI, Antônio Flávio. De olho na modernidade religiosa. Tempo soc., São Paulo, v. 20, n. 2, p. 9-16, Nov. 2008

PIERUCCI, Antonio Flávio. Reencantamento e dessecularização: a propósito do auto-engano em sociologia da religião. Novos Estudos Cebrap, n.49, p. 99-119, 1997.

PIERUCCI, Antônio Flávio. Secularização em Max Weber: Da contemporânea serventia de voltarmos a acessar aquele velho sentido. Rev. bras. Ci. Soc., São Paulo, v. 13, n. 37, p. 43-73, Junho, 1998.

PIERUCCI, Antônio Flávio .O desencantamento do Mundo. Todos os passos do conceito em MaxWeber. 1. ed. São Paulo, Ed. 34, 2003. 
PIERUCCI, A. F. Cadê nossa diversidade religiosa? Comentários ao texto de Marcelo Camurça. In: TEIXEIRA, F.; MENEZES, R. (Eds.). As Religiões no Brasil: Continuidades e rupturas. Petrópolis: Vozes, 2006. p. 49-51.

QUEIROZ, M. I. P. Relatos orais: do “indizível” ao “dizível”. In: VON SIMSON, O. M. (org. e intr.). Experimentos com histórias de vida (Itália-Brasil). São Paulo: Vértice, Editora Revista dos Tribunais, Enciclopédia Aberta de Ciências Sociais, v.5, 1988. p. 68-80

QUINTANA, Eduardo. Intolerância Religiosa na Escola: O que professoras filhas de santo tem a dizer sobre esta forma de violência. ITABAIANA: GEPIADDE, Ano 07, volume 14/ jul.-dez. 2013. pp.127-140.

DA ROCHA, Marcos Porto Freitas; DA ROCHA, Jose Geraldo; LIMA, Jacqueline de Cassia Pinheiro. Intolerância religiosa em escolas públicas no Rio de Janeiro. Educação. Revista do Centro de Educação, v. 41, n. 3, p. 709-718, 2016.

RANQUETAT JR, Cesar. Laicidade, laicismo e secularização: definindo e esclarecendo conceitos. Revista Sociais e Humanas, v. 21, n. 1, p. 67-75, 2008

RIBEIRO, Paulo Rennes Marçal. "História da educação escolar no Brasil: Notas para uma reflexão" In: Paideia, Ribeirão Preto, n 4, p. 15-30, 1993, p.15.

RODRIGUES, E. A formação do Estado secular brasileiro: notas sobre a relação entre religião, laicidade e esfera pública. Horizonte, vol 11, 2013.

RODRIGUES, F. T. P. . História na escola: os desafios da tolerância religiosa. In: XI Seminário Nacional de Formação dos Profissionais de Educação, 2017, Rio de Janeiro. I Seminário Nacional de Formação dos Profissionais de Educação ?Planos de Educação, Diretrizes e Bases Curriculares: Impactos na Formação dos Professores no Brasil? ANAIS, 2017. p. 436-438.

SANCHIS, Pierre. As religiões dos brasileiros. HORIZONTE-Revista de Estudos de Teologia e Ciências da Religião, v. 1, n. 2, p. 28-43, 1997.

SANTOS, Murilo Silva. O NEOPENTECOSTALISMO E A INTOLERÂNCIA RELIGIOSA PRATICADA CONTRA AS RELIGIÕES AFROBRASILEIRAS. UNITAS-Revista Eletrônica de Teologia e Ciências das Religiões, v. 5, n. 2, p. 422-438, 2017.

SARMENTO, D. O Crucifixo nos tribunais e a laicidade do Estado. Revista Eletrônica PRPE, v. 5, p. 1-17, 2007.

SETTON, M. (2008). As religiões como agentes da socialização. Cadernos CERU, 19(2), 15-25.

SILVA, ALLAN DO CARMO. Laicidade versus confessionalismo na escola pública: um estudo em Nova Iguaçu (RJ)' 134 f. Mestrado em EDUCAÇÃO 
Instituição de Ensino: UNIVERSIDADE FEDERAL DO RIO DE JANEIRO, Rio de Janeiro, 2013.

SILVA, Clemildo Anacleto. Desafios e propostas para promoção do reconhecimento da diversidade religiosa no Brasil. Estudos de religiao, v. 29, n. 2, p. 68-85, 2015.

SIMÕES, Solange. PEREIRA, Maria Aparecida Machado. A arte e a ciência de fazer perguntas: aspectos cognitivos da metodologia de survey e a construção do questionário. In: AGUIAR, Neuma. (coord.). Desigualdades sociais, redes de sociabilidade e participação política. Belo Horizonte: Editora UFMG, 2007, p. $249-69$.

SOFIATI, Flávio Munhoz. Perspectivas da laicidade no Brasil contemporâneo. Revista Semestral do Departamento e do Programa de PósGraduação em Sociologia da UFSCar, v. 5, n. 2, p. 327, 2015.

TEIXEIRA, Pedro; ANDRADE, Marcelo. Entre as crenças pessoais e a formação acadêmica: como professores de biologia que professam fé religiosa ensinam evolução?. Ciênc. educ. (Bauru), Bauru , v. 20, n. 2, p. 297-313， 2014

TEIXEIRA, PEDRO PINHEIRO. THE TEACHING OF EVOLUTION AND RELIGIOUSNESS: THE CASE OF TWO STATE SCHOOLS IN RIO DE JANEIRO. 2016.

TREVISAN, Janine. A Frente Parlamentar Evangélica: força política no estado laico brasileiro. Numen, v. 16, n. 1, 2013.

TURA, Maria de Lourdes. A observação do cotidiano escolar. In: Nadir Zago; Marília Pinto de Carvalho; Rita Amélia Teixeira Vilela. (Org.). Itinerários de pesquisa: perspectivas qualitativas em sociologia da educação. 2ed.Rio de Janeiro: Lamparina, 2011, v. 1, p. 183-206.

UNESCO. Declaração de princípios sobre a tolerância, 1995. disponível em: http://www.dhnet.org.br/direitos/sip/onu/paz/dec95.htm. Acesso em 27/01/2018

VALENTE, GABRIELA ABUHAB. A presença oculta da religiosidade na prática docente' .115 f. Mestrado em EDUCAÇÃO Instituição de Ensino: UNIVERSIDADE, 2015.

VALENTE, Gabriela Abuhab. A religiosidade na prática docente. Rev. Bras. Estud. Pedagog., Brasília , v. 98, n. 248, p. 198-211, Jan. 2017.

VOLTAIRE (François-Marie Arouet). Tratado sobre a tolerância: a propósito da morte de Jean Calas. Porto Alegre: L\&PM Pocket, 2011

ZAGO, Nadir. A entrevista e seu processo de construção: reflexões com base na experiência prática de pesquisa. In: ZAGO, Nadir; et al. Itinerários de pesquisa: abordagens qualitativas em sociologia da educação. Rio de Janeiro: DP\&A, 2003: 287-309. 


\section{8 Apêndices}

\section{Apêndice 1: Roteiro de entrevista com professores}

\section{Roteiro de entrevista com professores}

\section{Trajetória profissional}

Há quanto tempo você leciona?

E nessa escola?

Qual/is disciplina você leciona?

Para quais séries?

Você poderia descrever sua trajetória profissional e seu percurso de formação?

Por que escolheu essa profissão?

Você poderia falar dessa escola?

Você já participou de alguma atividade ou de algum projeto na sua escola que tratasse sobre a questão religiosa na escola?

\section{Diversidade religiosa no currículo}

Existe um espaço no currículo escolar para tratar da diversidade social e cultural dos alunos?

Conhece a religião dos alunos?

Situações da atualidade veiculadas pela mídia, já provocaram debates envolvendo essas temáticas religiosas?

Você já vivenciou, em sua atividade profissional, situações em que a diversidade religiosa dos alunos e de suas famílias fossem importantes? Poderia dar exemplos? (Como você agiu? Como terminou a situação?)

\section{Atitude do profissional nessas situações}

Você já atuou em escolas que promoviam o Ensino Religioso? (Como a disciplina era desenvolvida? O que você acha da disciplina? Na ocasião, você chegou a trabalhar ou desenvolver algum trabalho junto com o professor de ER, no quadro de interdisciplinaridade)?

Você conhece a lei 10.639? O que você acha da Lei 10639 - sobre ensino da história e cultura africanas na escola? (Já teve alguma vivência dentro da perspectiva dessa lei? Qual foi sua ação? Qual era o objetivo do projeto? Como os alunos receberam)?

\section{A justificação da ação, dos princípios de referência mobilizados}

A propósito das situações mencionadas: por que você agiu dessa forma?

Percurso: você acredita que existe uma ligação entre suas escolhas, sua ação nessas situações e a escola que você trabalha?

Você acredita que as orientações da direção e coordenação da escola influenciaram na sua ação? 
V. As necessidades de formações, de recursos, de acompanhamentos

O que é necessário em sua atividade profissional para lidar com a questão da laicidade na escola?

Você acha que a escola é um lugar para a resolução dos conflitos de intolerância religiosa?

A escola que você leciona é laica? Qual é sua opinião sobre isso?

Você vê alguma relação entre religião, laicidade e tolerância religiosa?

Quais são as questões importantes para lidar com a diversidade religiosa na escola? 


\section{Apêndice 2: Roteiro de entrevistas com alunos}

\section{Roteiro entrevista com alunos:}

I: Percurso pessoal:

1-Nome

2-Idade

3-Há quanto tempo estuda nessa escola? Sempre estudou em escola pública? ( onde estudou antes? Qual a diferença entre as escolas?

4- Fale um pouco sobre sua turma atual. Como é o relacionamento entre os colegas? Como é o relacionamento com os professores?

5- Você se lembra como era sua turma no ano passado? Como era o relacionamento entre os colegas?

\section{Perguntas sobre religião:}

1- Você se considera uma pessoa religiosa? Qual a sua religião?

2- Em uma escala de 0 a 10, qual a importância da religião na sua vida?

3- Você considera que sua religião afeta no seu comportamento na escola? Como?

\section{III: Preconceito}

1- Você já vivenciou alguma situação de preconceito na escola? Como foi? Como reagiu?

2- Você já presenciou alguma situação em que a religião de algum aluno ou professor fosse alvo de preconceito na escola? Como foi? Como reagiu?

3- Você já sofreu algum tipo de preconceito na escola? Como foi? Qual foi sua reação? 


\section{Apêndice 3: Termos de consentimento}

PONTIFÍCIA UNIVERSIDADE CATÓLICA DO RIO DE JANEIRO

Programa de Pós-Graduação em Educação

PU $\mathrm{U}_{\mathrm{R}}$ TERMO de CONSENTIMENTO LIVRE E ESCLARECIDO | PROFESSORES

Prezado/a:

Vimos, por meio deste, convidar-Ihe a participar voluntariamente da pesquisa apresentada a seguir.

Pesquisa: A religião no cotidiano escolar: desafios da tolerância

Pesquisadores:

Mestrando: Fabiano Rodrigues

Orientador: Prof. Dr. Pedro Teixeira

$\mathrm{Eu}$,

de maneira voluntária, livre e esclarecida, concordo em participar da pesquisa acima identificada. Estou ciente dos objetivos do estudo, dos procedimentos metodológicos, dos possíveis desconfortos com o tema, das garantias de confidencialidade e da possibilidade de esclarecimentos permanentes sobre os mesmos. Fui informado(a) de que se trata de pesquisa de Mestrado em andamento no Programa de Pós-Graduação em Educação da PUC-Rio. Está claro que minha participação é isenta de despesas e que minha imagem e meu nome não serão publicados sem minha prévia autorização por escrito, bem como de meu responsável. Estou de acordo com a áudiogravação da entrevista a ser cedida para fins de registros acadêmicos. Estou ciente de que, em qualquer fase da pesquisa, tenho a liberdade de recusar a minha participação ou retirar meu consentimento, sem nenhuma penalização ou prejuízo que me possam ser imputados.

Mestrando

[assinatura do/a professor/a voluntário/a] 


\section{PONTIFÍCIA UNIVERSIDADE CATÓLICA DO RIO DE JANEIRO \\ Programa de Pós-Graduação em Educação}

PU

Prezado/a:

Vimos, por meio deste, solicitar sua autorização como responsável para convidar seu filho a participar voluntariamente da pesquisa apresentada a seguir.

Pesquisa: A religião no cotidiano escolar: desafios da tolerância

Pesquisadores:

Mestrando: Fabiano Taranto

Orientador: Prof. Dr. Pedro Teixeira

$\mathrm{Eu}$ responsável por

de maneira voluntária, livre e esclarecida, autorizo a participação do/a mesmo/a na pesquisa acima identificada. Estou ciente dos objetivos do estudo, dos procedimentos metodológicos, dos possíveis desconfortos com o tema, das garantias de confidencialidade e da possibilidade de esclarecimentos permanentes sobre os mesmos. Fui informado(a) de que se trata de pesquisa de mestrado em andamento no Programa de Pós-Graduação em Educação da PUC-Rio. Está claro que minha participação é isenta de despesas e que a imagem e o nome dos envolvidos na pesquisa não serão publicados sem minha prévia autorização por escrito. Estou de acordo com o uso de questionário e a áudio-gravação da entrevista a ser cedida para fins de registros acadêmicos. Estou ciente de que, em qualquer fase da pesquisa, tenho a liberdade de recusar a participação ou retirar meu consentimento, sem nenhuma penalização ou prejuízo que me possam ser imputados. 
Apêndice 4: Formulário de identificação dos professores

Pontifícia Universidade Católica $_{\text {a }}$ DO RIO DE JANEIRO

Grupo de Estudos sobre o Cotidiano, Educaçăo e Cultura(s)

Prática Pedagógica e Ética Intercultural

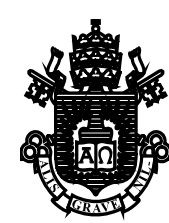

PUC

FORMULÁRIO DE IDENTIFICAÇÃO

\begin{tabular}{|l|l|}
\hline Nome: & \\
\hline Idade: & \\
\hline
\end{tabular}

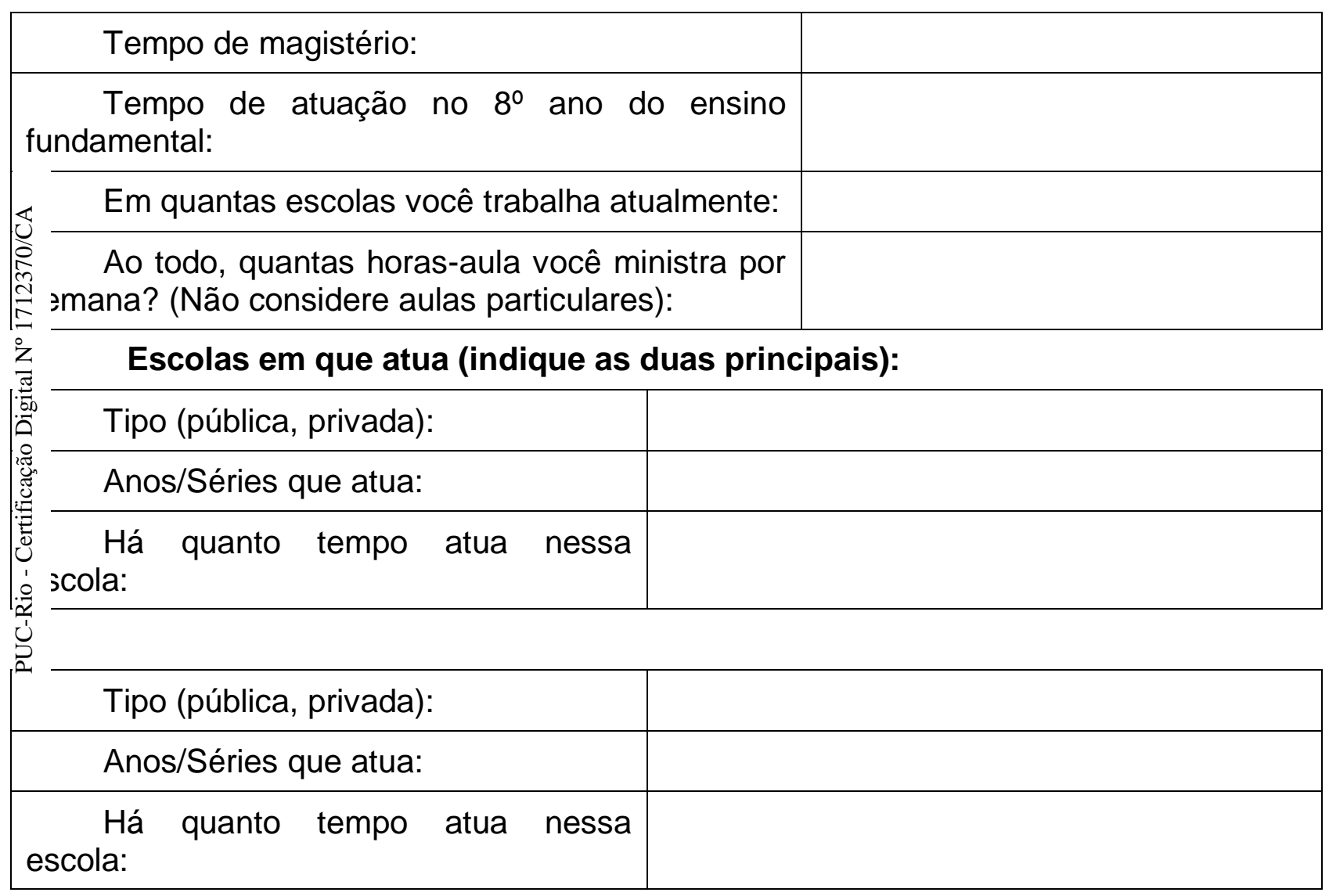

Formação | Graduação

\begin{tabular}{|l|l|}
\hline Curso: & \\
\hline Instituição: & \\
\hline Ano de término & \\
\hline
\end{tabular}

$\square$ Apenas licenciatura

$\square$ Apenas bacharelado $\square$ Licenciatura e bacharelado 
Formação | Pós-Graduação (indique no máximo duas)

\begin{tabular}{|l|l|}
\hline Curso: & \\
\hline Instituição: & \\
\hline Ano de término & \\
\hline
\end{tabular}

\begin{tabular}{|l|l|}
\hline Curso: & \\
\hline Instituição: & \\
\hline Ano de término: & \\
\hline
\end{tabular}

\section{Religião}

\begin{tabular}{|c|c|}
\hline \multicolumn{2}{|l|}{ Denominação: } \\
\hline \multicolumn{2}{|l|}{ Tempo de confissão: } \\
\hline \multirow{2}{*}{$\begin{array}{l}\text { Funções que exerce: } \\
\text { (Indique até duas) }\end{array}$} & $1-$ \\
\hline & $2-$ \\
\hline \multirow{2}{*}{$\begin{array}{l}\overleftrightarrow{\mho}^{\text {upos que participa: }} \\
\quad \text { (Indique até dois) }\end{array}$} & 1 - \\
\hline & $2-$ \\
\hline \multicolumn{2}{|c|}{ Outras Atividades } \\
\hline \multicolumn{2}{|c|}{$\begin{array}{l}\text { Você participa de algum outro grupo (partido, sindicato, ONG, } \\
\text { grupo cultural, grupo de estudo)? Se sim, quais? }\end{array}$} \\
\hline
\end{tabular}


Apêndice 5: Tabela com perfil dos professores

\begin{tabular}{|c|c|c|c|c|}
\hline Professor & Idade & $\begin{array}{l}\text { Tempo no } \\
\text { magistério }\end{array}$ & Formação & Religião \\
\hline $\mathrm{P} 1$ & 56 anos & 28 anos & $\begin{array}{l}\text { Licenciatura em } \\
\text { Ciências Sociais pela } \\
\text { UERJ } \\
\text { Pós-Graduação em } \\
\text { história das relações } \\
\text { internacionais UERJ }\end{array}$ & Sem religião \\
\hline $\mathrm{P} 2$ & 45 anos & 23 anos & $\begin{array}{l}\text { Licenciatura e } \\
\text { Bacharelado em } \\
\text { Ciências Biológicas na } \\
\text { UFF } \\
\text { Pós-Graduação em } \\
\text { patologia clínica pela } \\
\text { Souza Marques }\end{array}$ & Evangélica \\
\hline P3 & 61 anos & 30 anos & $\begin{array}{l}\text { Licenciatura em } \\
\text { biologia pela USP } \\
\text { Mestrado e doutorado } \\
\text { em psicologia pela } \\
\text { USP }\end{array}$ & Católica \\
\hline
\end{tabular}


Apêndice 6: Perfis dos alunos entrevistados

\begin{tabular}{|c|c|c|c|c|}
\hline Aluno & Idade & Cor & Sexo & Religião \\
\hline A1 & 15 anos & Branco & Masculino & Sem Religião \\
\hline A2 & 14 anos & Parda & Feminino & Evangélica \\
\hline A3 & 14 anos & Pardo & Masculino & Evangélico \\
\hline A4 & 14 anos & Negra & Feminino & Católica \\
\hline
\end{tabular}




\section{Apêndice 7: Questionário aplicado aos alunos}

\section{PUC-Rio | Departamento de Educação}

Número:

Prezado/a estudante:

- Você está participando de uma pesquisa para a universidade.

- $\quad$ Este questionário não é uma prova.

- $\quad$ Não existe resposta certa ou errada.

- $\quad$ Responda de acordo com o que você pensa.

- Caso tenha dúvida sobre alguma palavra, você pode perguntar.

Leia as frases e marque a tabela de acordo com a sua opinião.

1. As mulheres têm que cozinhar melhor que os homens.

2. A gente deve ficar chateado quando um colega de turma é zoado.

3. Crianças com deficiência atrapalham a aula.

4. Os alunos que sofrem bullying merecem ser zoados.

5. Todo mundo tem que ter uma religião.

6. Arrumar a cama e lavar a louça é coisa de menina.

7. Meninos podem brincar de boneca.

8. Meninas de cabelo crespo devem alisar o cabelo.

9. Zoar o colega na escola é só uma brincadeira.

10. Estudantes negros conseguem tirar notas tão boas como os brancos.

11. Quem não acredita em Deus vai para o inferno.

12. Os estudantes com deficiência deveriam estudar em escolas especiais.

13. Meninas precisam de mais ajuda da professora nos trabalhos da escola do que os meninos.

\begin{tabular}{|c|c|c|c|}
\hline $\begin{array}{l}\text { DISCORDO } \\
\text { MUITO }\end{array}$ & DISCORDO & CONCORDO & $\begin{array}{l}\text { CONCORDO } \\
\text { MUITO }\end{array}$ \\
\hline & & & \\
\hline & & & \\
\hline & & & \\
\hline & & & \\
\hline & & & \\
\hline & & & \\
\hline & & & \\
\hline & & & \\
\hline & & & \\
\hline & & & \\
\hline & & & \\
\hline & & & \\
\hline & & & \\
\hline
\end{tabular}




\begin{tabular}{|c|c|c|c|c|}
\hline $\begin{array}{l}\text { Leia as frases e marque a tabela de acordo com a } \\
\text { sua opinião. }\end{array}$ & $\begin{array}{l}\text { DISCORDO } \\
\text { MUITO }\end{array}$ & DISCORDO & CONCORDO & $\begin{array}{l}\text { CONCORDO } \\
\text { MUITO }\end{array}$ \\
\hline \multicolumn{5}{|l|}{$\begin{array}{l}\text { 14. Ficar chateado com a zoação dos colegas é } \\
\text { bobagem. }\end{array}$} \\
\hline \multicolumn{5}{|l|}{$\begin{array}{l}\text { 15. Meninos devem cuidar mais da aparência do que } \\
\text { as meninas. }\end{array}$} \\
\hline \multicolumn{5}{|l|}{$\begin{array}{l}\text { 16. Professores gostam mais de alunos negros do que } \\
\text { brancos. }\end{array}$} \\
\hline \multicolumn{5}{|l|}{$\begin{array}{l}\text { 17. Todos os evangélicos são fanáticos (radicais, } \\
\text { exagerados). }\end{array}$} \\
\hline \multicolumn{5}{|l|}{ 18. Pessoas com deficiência devem ficar em casa. } \\
\hline \multicolumn{5}{|l|}{$\begin{array}{l}\text { 19. Os professores têm que impedir que o bullying } \\
\text { aconteça. }\end{array}$} \\
\hline \multicolumn{5}{|l|}{ 20. O homem deve ser o chefe da família. } \\
\hline \multicolumn{5}{|l|}{$\begin{array}{l}\text { 21. Situações de bullying devem ser resolvidas pelos } \\
\text { próprios alunos. }\end{array}$} \\
\hline \multicolumn{5}{|l|}{ 22. O candomblé é uma religião do demônio. } \\
\hline \multicolumn{5}{|l|}{$\begin{array}{l}\text { 23. Alunos com deficiência devem realizar tarefas } \\
\text { escolares com os alunos sem deficiência. }\end{array}$} \\
\hline \multicolumn{5}{|l|}{ 24. Meninas só podem namorar meninos. } \\
\hline \multicolumn{5}{|l|}{ 25. Pessoas negras são mais bonitas do que brancas. } \\
\hline \multicolumn{5}{|l|}{$\begin{array}{l}\text { 26. Estudantes negros precisam se esforçar mais para } \\
\text { aprender do que estudantes brancos. }\end{array}$} \\
\hline \multicolumn{5}{|l|}{$\begin{array}{l}\text { 27. Alunos do candomblé e da umbanda podem usar } \\
\text { suas guias (colares de santo) na escola. }\end{array}$} \\
\hline \multicolumn{5}{|l|}{$\begin{array}{l}\text { 28. Deve existir uma sala separada para alunos } \\
\text { deficientes na escola. }\end{array}$} \\
\hline \multicolumn{5}{|l|}{$\begin{array}{l}\text { 29. O número de deficientes nas escolas é pequeno } \\
\text { para se preocupar com eles. }\end{array}$} \\
\hline \multicolumn{5}{|l|}{$\begin{array}{l}\text { 30. Alunos evangélicos podem se recusar a fazer } \\
\text { trabalhos escolares sobre religiões africanas. }\end{array}$} \\
\hline \multicolumn{5}{|l|}{$\begin{array}{l}\text { 31. Apenas as crianças sem deficiência conseguem } \\
\text { aprender a matéria que a professora ensina. }\end{array}$} \\
\hline \multicolumn{5}{|l|}{$\begin{array}{l}\text { 32. Estudantes brancos são mais inteligentes do que } \\
\text { negros. }\end{array}$} \\
\hline \multicolumn{5}{|l|}{$\begin{array}{l}\text { 33. Os alunos que implicam com os outros são mais } \\
\text { maneiros. }\end{array}$} \\
\hline \multicolumn{5}{|l|}{$\begin{array}{l}\text { 34. A Bíblia é mais correta que a ciência para explicar a } \\
\text { origem dos seres humanos. }\end{array}$} \\
\hline 35. Os meninos podem beijar um amigo. & & & & \\
\hline
\end{tabular}




\begin{tabular}{|c|c|c|c|c|}
\hline $\begin{array}{l}\text { Leia as frases e marque a tabela de acordo com a } \\
\text { sua opinião. }\end{array}$ & $\begin{array}{l}\text { DISCORDO } \\
\text { MUITO }\end{array}$ & DISCORDO & CONCORDO & $\begin{array}{l}\text { CONCORDO } \\
\text { MUITO }\end{array}$ \\
\hline \multicolumn{5}{|l|}{$\begin{array}{l}\text { 36. Meninos negros são melhores em atividades físicas } \\
\text { do que meninos brancos. }\end{array}$} \\
\hline \multicolumn{5}{|l|}{ 37. Os alunos que fazem bullying precisam de ajuda. } \\
\hline \multicolumn{5}{|l|}{ 38. Imagens de santos não fazem milagres. } \\
\hline \multicolumn{5}{|l|}{$\begin{array}{l}\text { 39. Estudantes brancos gostam mais de fazer bagunça } \\
\text { do que estudantes negros. }\end{array}$} \\
\hline \multicolumn{5}{|l|}{$\begin{array}{l}\text { 40. Pessoas com deficiência conseguem ser bons } \\
\text { profissionais. }\end{array}$} \\
\hline \multicolumn{5}{|l|}{$\begin{array}{l}\text { 41. É natural que meninos saibam mais matemática } \\
\text { que meninas. }\end{array}$} \\
\hline \multicolumn{5}{|l|}{$\begin{array}{l}\text { 42. Meninos têm que gostar das aulas de Educação } \\
\text { Física. }\end{array}$} \\
\hline \multicolumn{5}{|l|}{$\begin{array}{l}\text { 43. Quem sofre bullying tem que aprender a se } \\
\text { defender sozinho. }\end{array}$} \\
\hline \multicolumn{5}{|l|}{$\begin{array}{l}\text { 44. Chamar um colega por apelido, como "macaco", é } \\
\text { só uma brincadeira. }\end{array}$} \\
\hline \multicolumn{5}{|l|}{ 45. Só existe uma religião verdadeira. } \\
\hline \multicolumn{5}{|l|}{$\begin{array}{l}\text { 46. Os alunos com deficiência criam problemas na } \\
\text { escola. }\end{array}$} \\
\hline \multicolumn{5}{|l|}{$\begin{array}{l}\text { 47. Estudantes negros merecem mais castigo dos } \\
\text { professores do que estudantes brancos. }\end{array}$} \\
\hline \multicolumn{5}{|l|}{$\begin{array}{l}\text { 48. Os colegas de turma devem ajudar o aluno que } \\
\text { sofre bullying. }\end{array}$} \\
\hline \multicolumn{5}{|l|}{$\begin{array}{l}\text { 49. É bom quando a professora reza na aula com os } \\
\text { alunos. }\end{array}$} \\
\hline $\begin{array}{l}\text { 50. Alunos com deficiência conseguem tirar notas tão } \\
\text { boas quanto os alunos sem deficiência. }\end{array}$ & & & & \\
\hline
\end{tabular}




\begin{tabular}{|c|c|c|c|c|c|}
\hline \multicolumn{2}{|c|}{$\begin{array}{l}\text { Responda às perguntas sobre o que acontece } \\
\text { na sua escola. }\end{array}$} & NUNCA & $\begin{array}{l}\text { POUCAS } \\
\text { VEZES }\end{array}$ & $\begin{array}{l}\text { MUITAS } \\
\text { VEZES }\end{array}$ & SEMPRE \\
\hline \multicolumn{2}{|c|}{ 51. Você já sofreu bullying na escola? } & & & & \\
\hline \multicolumn{2}{|c|}{$\begin{array}{l}\text { 52. Você já sofreu preconceito na escola por causa } \\
\text { de sua religião ou por não ter religião? }\end{array}$} & & & & \\
\hline \multicolumn{2}{|c|}{$\begin{array}{l}\text { 53. Você já sofreu preconceito na escola por causa } \\
\text { da cor da sua pele? }\end{array}$} & & & & \\
\hline \multicolumn{2}{|c|}{$\begin{array}{l}\text { 54. Você já sofreu preconceito na escola por causa } \\
\text { de alguma limitação física? }\end{array}$} & & & & \\
\hline \multicolumn{2}{|c|}{$\begin{array}{l}\text { 55. Você já sofreu preconceito na escola por causa } \\
\text { do seu local de moradia? }\end{array}$} & & & & \\
\hline \multirow[b]{2}{*}{$\begin{array}{l}\text { 56. Questões para } \\
\text { as meninas: }\end{array}$} & $\begin{array}{l}\text { Você já sofreu preconceito na } \\
\text { escola por ser menina? }\end{array}$ & & & & \\
\hline & $\begin{array}{l}\text { Você já sofreu preconceito na } \\
\text { escola por não se comportar } \\
\text { como uma menina? }\end{array}$ & & & & \\
\hline \multirow{2}{*}{$\begin{array}{l}\text { 57. Questões para } \\
\text { os meninos: }\end{array}$} & $\begin{array}{l}\text { Você já sofreu preconceito na } \\
\text { escola por ser menino? }\end{array}$ & & & & \\
\hline & $\begin{array}{l}\text { Você já sofreu preconceito na } \\
\text { escola por não se comportar } \\
\text { como um menino? }\end{array}$ & & & & \\
\hline
\end{tabular}


58. Qual o bairro em que você mora?

59. Qual o seu sexo?

$\square$ Masculino $\square$ Feminino

60. Dia do seu nascimento:

$\frac{}{(\mathrm{DIA})} / \frac{}{(\mathrm{ME} S)} / \overline{\text { (ANO) }}$

61. Como você se considera?RAÇA

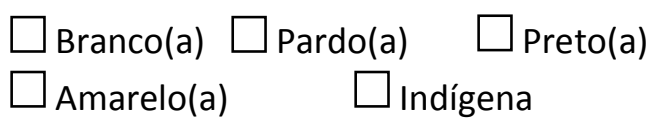

62. Na sua casa tem computador?

$\square$ sim, com internet. $\square$ sim, sem internet. $\square$ Não.

63. Você tem celular ou smartfone?

$\square$ sim, com internet. $\square$ sim, sem internet. $\square$ Não.

64. Incluindo você, quantas pessoas vivem atualmente em sua casa?

$\square$ Duas. $\square$ Três. $\square$ Quatro

$\square$ cinco. $\square$ seis pessoas ou mais

65. Você mora com sua mãe?

$\square$ sim. $\square$ Não. Moro com outra Iulher responsável por mim.

$\square$ Não (passe para a questão no 69)

66. Até que série sua mãe ou a mulher responsável por você estudou?

$\square$ Nunca estudou. primário).

Não completou o 5o ano (antigo

Completou o 5o ano, mas não completou o 9o ano (antigo ginásio).

Completou o 9 ano, mas não completou o Ensino Médio (antigo 2 o grau).

Completou o Ensino Médio, mas não completou a Faculdade.

$\square$ Completou a Faculdade.

$\square$ Não sei.

67. Sua mãe ou a mulher responsável por você sabe ler e escrever?

$\square$ sim. $\square$ Não. $\square$ Não sei.
68. Você vê sua mãe ou a mulher responsável por você lendo?

$\square$ Sim. $\square$ Não.

69. Você mora com seu pai?

$\square \operatorname{sim}$

$\square$ Não. Moro com outro homem responsável por mim.

$\square$ Não (passe para a questão no 73)

70. Até que série seu pai ou o homem responsável por você estudou?

$\square$ Nunca estudou.

Não completou o 5o ano (antigo primário).

$\square$ Completou o 5o ano, mas não completou o 9o ano (antigo ginásio).

$\square$ Completou o 9o ano, mas não completou o Ensino Médio (antigo 20 grau).

Completou o Ensino Médio, mas não completou a Faculdade.

$\square$ Completou a Faculdade.

Não sei.

71. Seu pai ou o homem responsável por você sabe ler e escrever?

$\square$ Sim. $\square$ Não. $\quad \square$ Não sei.

72. Você vê o seu pai ou o homem responsável por você lendo?

$\square$ Sim. $\square$ Não.

73. Seus pais ou responsáveis incentivam você a fazer o dever de casa e/ou os trabalhos da escola?

$\square$ sim. $\quad \square$ Não.

74. Seus pais ou responsáveis incentivam você a ir à escola e não faltar às aulas?

$\square$ sim.

$\square$ Não.

75. Seus pais ou responsáveis conversam com você sobre o que acontece na escola?

$\square$ sim. $\square$ Não.

76. Você trabalha fora de casa?

$\square$ Sim. $\square$ Não. 
77. Em dias de aula, quanto tempo você gasta fazendo trabalhos domésticos (ex.: lavando a louça, limpando o quintal)?

$\square$ Menos de 1 hora.

$\square$ Entre 1 e 2 horas.

$\square$ Mais de 2 horas, até 3 horas.

$\square$ Mais de 3 horas.

$\square$ Não faço trabalhos domésticos.

78. Desde o 10 ano do ensino fundamental, em que tipo de escola você estudou?

$\square$ somente escola pública.

$\square$ somente em escola particular.

$\square$ Em escola pública e em escola particular.

79. Você já foi reprovado?

$\square$ Não

$\square$ sim, uma vez.

$\square$ sim, duas vezes ou mais

80. Você já abandonou a escola durante o período de aulas e ficou fora da escola o resto do ano?

$\square$ Não

$\square$ sim, uma vez.

$\square$ sim, duas vezes ou mais

81. Você gosta de estudar língua portuguesa?

$\square$ Sim. $\square$ Não.

82. Você faz o dever de língua portuguesa?

$\square$ sempre ou quase sempre.

$\square$ De vez em quando.

$\square$ Nunca ou quase nunca.

$\square$ A professora não passa dever de casa.

83. A professora corrige 0 dever de língua portuguesa?

$\square$ sempre ou quase sempre.

$\square$ De vez em quando.

$\square$ Nunca ou quase nunca.

84. Você gosta de estudar matemática? $\square \operatorname{sim}$. $\square$ Não.

85. Você faz o dever de matemática? Sempre ou quase sempre. $\square$ De vez em quando.

$\square$ Nunca ou quase nunca.

$\square$ A professora não passa dever de casa.

86. A professora corrige 0 dever de matemática?

$\square$ sempre ou quase sempre.

$\square$ De vez em quando.

$\square$ Nunca ou quase nunca.

87. Com que frequência você vai a um templo ou outro encontro religioso? (Marque apenas uma alternativa)

$\square$ Mais do que uma vez por semana.

$\square$ Uma vez por semana.

$\square$ Duas ou mais vezes por mês.

$\square$ Algumas vezes por ano.

$\square$ Nunca.

88. Com que frequência você realiza atividades religiosas individuais, como preces, rezas, meditações, oferendas, leituras da Bíblia ou de outros textos religiosos? (Marque apenas uma alternativa):

$\square$ Mais do que uma vez ao dia.

$\square$ Uma vez ao dia.

$\square$ Duas ou mais vezes por semana

$\square$ Uma vez por semana

$\square$ Uma vez por mês ou menos.

$\square$ Nunca.

89. Quanto à sua religião, você é:

Acredito em Deus, mas não tenho religião.

$\square$ Ateu.

$\square$ Candomblecista.

$\square$ Católico.

$\square$ Espírita Kardecista.

$\square$ Evangélico.

$\square$ Testemunha de Jeová.

$\square$ Umbandista.

$\square$ Outro. Qual? 